Florida International University FIU Digital Commons

3-21-2017

\title{
From the Fall to the Flood and Beyond: Navigating Identity in Contemporary Noahidism
}

Patrick J. Villalonga

Florida International University, pvill015@fiu.edu

DOI: $10.25148 /$ etd.FIDC001820

Follow this and additional works at: https:// digitalcommons.fiu.edu/etd

Part of the Biblical Studies Commons, Comparative Methodologies and Theories Commons, Ethics in Religion Commons, Jewish Studies Commons, New Religious Movements Commons, Other Religion Commons, and the Religious Thought, Theology and Philosophy of Religion Commons

\section{Recommended Citation}

Villalonga, Patrick J., "From the Fall to the Flood and Beyond: Navigating Identity in Contemporary Noahidism" (2017). FIU

Electronic Theses and Dissertations. 3127.

https://digitalcommons.fiu.edu/etd/3127 


\section{FLORIDA INTERNATIONAL UNIVERSITY}

Miami, Florida

FROM THE FALL TO THE FLOOD AND BEYOND:

NAVIGATING IDENTITY IN CONTEMPORARY NOAHIDISM

A thesis submitted in partial fulfillment of the

requirements for the degree of

MASTER OF ARTS

in

RELIGIOUS STUDIES

by

Patrick Joaquin Villalonga 
To: Dean John F. Stack

Steven J. Green School of International and Public Affairs

This thesis, written by Patrick Joaquin Villalonga, and entitled From the Fall to the Flood and Beyond: Navigating Identity in Contemporary Noahidism, having been approved in respect to style and intellectual content, is referred to you for judgment.

We have read this thesis and recommend that it be approved.

$\begin{array}{r}\text { Oren Stier } \\ \hline \text { Erik Larson } \\ \hline \text { Tudor Parfitt, Major Professor }\end{array}$

Date of Defense: March 21, 2017

The thesis of Patrick Joaquin Villalonga is approved.

Dean John F. Stack

Steven J. Green School of International and Public Affairs

Andrés G. Gil

Vice President for Research and Economic Development and Dean of the University Graduate School

Florida International University, 2017 
(C) Copyright 2017 Patrick Joaquin Villalonga

All rights reserved. 


\section{DEDICATION}

To my parents, Mayra and Eduardo Villalonga, for your tender love, your tough love, your undying support, and for helping to guide me along my way.

To my friends, Michael Matos, Ralf Noya, and Solsiree Skarlinsky, for your affection, your insight, and for trusting in my madness.

To those who have unknowingly kept me smiling throughout graduate school: Robin Pecknold, Ben Bridwell, Ram Dass, and Katt Williams.

To my sisters, Nina and Sofia. Your love and example have been bottomless sources of inspiration; I've picked up the Phone. 


\section{ACKNOWLEDGMENTS}

This thesis is an attempt to sketch the contemporary Noahide movement, although not in a comprehensive manner. This is a first attempt at a rigorous and systematic study of this blossoming phenomenon, from the vantage point of English-speaking academia. Limited resources and time have narrowed the scope of my work, which may jeopardize the accuracy of my analysis to some degree. Nevertheless, I remain convinced I have produced an honest analysis of contemporary Noahidism, conducted with the utmost academic integrity. For this, I have to thank various individuals.

Rabbi Michael Shelomo Bar-Ron, for his insight and hospitality during a shabbat in Fort Lauderdale. Rabbi Yakov Dovid Cohen, for his hospitality in guiding me around Crown Heights. Mr. Michael Dallen for his insight. Dr. Michael Schulman, for his hospitality on my visit to Pittsburgh and his insight into the blossoming of the online Noahide movement. Mr. Alan Cecil, for sharing his ideas and outlook regarding the Noahide laws. Dr. David Novak, whose research and dialogue helped me understand the theoretical background of Noahidism. Rabbi Levi Friedman of ChabadFIU, whose humor and insight helped me get my work off the ground.

Dr. Erik Larson, whose example and knowledge have inspired me to dig deeper into this subject. Dr. Oren Stier, whose wit and encouragement have been ever so helpful during those times when I wasn't quite sure what I was doing. Dr. Tudor Parfitt, whose support and passion have helped offset pangs of procrastination and self-doubt. But, most importantly, I thank him for his example and encouragement which have helped me step 
out of my comfort zone and study something as complex and alive as Noahide identity. It would also be remiss of me not to acknowledge his financial support and the support of the FIU Jonathan Symons Fellowship Program. The Program, its lecture series, and Dr. Parfitt's seminars have exposed me to a wealth of Jewish culture and history, without which I would have much less of an understanding of Judaism.

Lastly, I must thank those who completed the Noahide Individuals Survey. The survey has yielded a great amount of information. In addition, I have to thank those who emailed me during the course of my research to share their encouragement and excitement about my work.

I would like to add a quick autobiographical note before my introduction. From 2011-2013, I seriously considered conversion to Orthodox Judaism, but ultimately turned to Noahidism. I began this project in 2014 as a self-proclaimed Noahide, but I have now recanted my association with Noahidism and see myself as an agnostic who, at most, hopes for the truth of deism and advocates religious pluralism as a practice. This shift occurred in part due to personal factors I need not mention, but also because of the research I conducted and the conclusions I have reached about Noahidism. I do feel it is important to be candid about my religious background and my current affiliations because some readers are bound to wonder for whatever reason — be it sheer curiosity, a commitment to post-modern analysis, etc. If there are mistakes in my analysis (and there are bound to be), I offer my sincere apologies and I would be very happy to make corrections. 
In this thesis I occasionally flesh out inconsistencies or dilemmas I have found lurking in Noahidism. My contentions with various aspects of contemporary Noahide ideology and practice are not indictments of Noahidism as a conceptual system or way of life, that is, my critique does not aim to invalidate or condemn Noahidism. I place no moral or ethical judgments on Noahide concepts or behaviors. Instead, I aspire to provide some insights into the true nature of the contemporary movement as a living, breathing phenomenon, part of which includes confronting the issues inherent in the movement. I hope the Noahide, Orthodox Jewish, and academic communities accept my work as a humble offering. 


\begin{abstract}
OF THE THESIS
FROM THE FALL TO THE FLOOD AND BEYOND:

NAVIGATING IDENTITY IN CONTEMPORARY NOAHIDISM
\end{abstract}

by

Patrick Joaquin Villalonga

Florida International University, 2017

Miami, Florida

Professor Tudor Parfitt, Major Professor

This thesis investigates artifacts and concepts present in the Noahide world and how they affect Noahide identity. Five factors are analyzed, namely Noahide law, religious pluralism, ritual, sectarianism, and conversion. I consult the Hebrew Scriptures as well as early, medieval, and modern rabbinic sources to set the conceptual background of the Noahide movement before moving into the primary, contemporary sources written by Orthodox Jews, Orthodox rabbis, and Noahides. To supplement my literary analysis, I have conducted a survey of self-identifying Noahide practitioners. This survey collects data concerning religious background, religious behavior, demographics, and free responses. I aim to show first and foremost that Noahidism is a new, exclusive religious tradition which comprises the lay order of Orthodox Judaism. This is born out of a theology which requires belief in the Jewish God and Jewish revelation, a strict ritual system based on Orthodox Jewish prescriptions, and a sectarian typology which mirrors 
Orthodox Jewish sectarianism. Additionally, my analysis of conversion shows Noahidism is not a gateway to Orthodox conversion, but an end in itself. 


\section{TABLE OF CONTENTS}

CHAPTER

INTRODUCTION 1

What is Noahidism? 2

Objectives 5

Methodology 10

Other 11

CHAPTER 1. LITERATURE REVIEW 13

What are the Noahide Laws? 13

Applications of Noahide Law 20

Understanding the Living Noahide Movement 25

CHAPTER 2. IDENTITY AND THE LAWS OF NOAH 28

The Code as a Body of Negative Law 28

Legislative and Judicial Power $\quad 32$

Rationality and the Noahide Laws 38

Punishment and the Noahide Laws $\quad 50$

CHAPTER 3. IDENTITY AND RELIGIOUS PLURALISM 54

The Noahide Laws as a Medium for Pluralism 56

Is Noahidism a Religion? $\quad 59$

Salvation $\quad 71$

Noahidism as an Exclusive Religion 73

The Noahide in Jewish Eschatology $\quad 84$

The Potential for Pluralism in Noahide Rhetoric 85

Noahidism as a Lay Tradition $\quad 93$

CHAPTER 4. IDENTITY AND NOAHIDE RITUAL 99

The Halakhah on Ritual 100

Ethical Precepts as Ritual 106

Torah and Contemplation 108

Prayer as Ritual $\quad 112$

Other Philosophical Innovations 113

$\begin{array}{ll}\text { Kabbalah and Ritual } & 117\end{array}$

CHAPTER 5. IDENTITY AND CONVERSION 125

$\begin{array}{ll}\text { Identifying as a Noahide } & 128\end{array}$

Identity and Conversion to Orthodox Judaism 134 
CONCLUSION

REFERENCES

APPENDICES 


\section{INTRODUCTION}

I believe it was Woody Allen who once told a good joke about a Russian Jew-a joke which reminds me of the way in which Jews often approach dilemmas.

Yaakov was a Jew in a small Russian town not long after the founding of the Soviet Union. One of the town's policemen, Captain Petrov, had seen Yaakov acting suspiciously for a few days now. One afternoon, the officer seized Yaakov, sat him down, and confronted him with the issue.

"Comrade Yaakov, what is all this suspicious behavior I see? Are you up to some mischief?!"

"Well, yes, Captain Petrov," Yaakov replied bashfully. "In all honesty, I am trying to flee the Soviet Union."

"What?! Why would you try doing such a thing?!" Comrade Petrov was incensed. Yaakov now became visibly uncomfortable. He fidgeted and could barely hold back his anxiety, but he was determined to be honest. "Well, you see Captain Petrov, there are two reasons. First of all, I don't want to be here when the Soviet Union falls. Everyone always blames the Jews when something goes wrong; you'll burn our houses, loot our business, and beat us in the streets."

"Comrade Yaakov, that is non-sense. You have no reason to be afraid. The Soviet Union will remain strong and prosperous for another thousand years!”

"Hmmm, yes, well that was my second reason for leaving." 
The joke of course is a poignant reminder of the dire state of Jewish-Gentile relations in Europe for the past two millennia. No matter what happened, it seemed, Jews were bound to suffer at the hands of their Gentile neighbors, whether in good times or in bad. But the joke also reminds me of how fluid Jewish thought and concepts can often be.

Noahidism is one such concept. At times it is invoked to demonstrate how Judaism is void of sociopolitical or ethnic concerns; it is merely a personal religion focused on the salvation of mankind. At other times Noahidism is brought as evidence to show how Judaism is not a religion at all, but rather an ethnic, ethical, and political entity mandated by God Himself; in this light, the laws of Noah reflect Judaism's socio-political slant because they provide a universal ethic through which all of mankind can also live meaningful lives in just societies. Noahidism as we find it today is, for better or for worse, full of meaning and complexity. It is as much a testament to the genius of rabbinic innovation and Jewish thought as it is also perplexing and exciting.

\section{What is Noahidism?}

Like most world religions, Judaism has never been a static entity. In the face of far-flung exiles, unabated oppression, as well as cultural and political evolutions and revolutions, the Jewish people, their customs, and their ideas have been subjected to decay, innovation, and renewal. As recently as the 20th century, Judaism saw the formation of the Conservative and Reconstructionist movements which greatly altered the landscape of Jewish identity. ${ }^{1}$ To a lesser extent, although not without much intrigue, the

\footnotetext{
${ }^{1}$ Dan Cohn-Sherbok, Judaism Today (New York: Continuum International Publishing Group, 2010), 88-109.
} 
synchretism between Judaism and Buddhism—-the so-called "JuBu" movement—also presented an interesting case in which the boundaries of Jewish identity shifted significantly. Just a hundred years after these developments, Judaism is once again on the cusp of another potentially significant moment in the history of religions.

Interestingly, this development affects not only Jewish identity, but actually nonJewish identity directly. The Noahide movement presents an opportunity for the fundamental transformation of Jewish-Gentile relations. More significant, however, is that Noahidism marks the emergence of a unique religious movement among the Abrahamic traditions.

The Noahide movement, Noahidism, or the Sons of Noah (B'nei Noach) denotes in general a religious movement closely related to Orthodox Judaism. As an ideology it has existed as a legal and philosophical fiction in rabbinic literature since the 2nd century B.C.E. According to these rabbinic sources, Noahidism is a universal ethical code that was given originally to Adam, expanded when given to Noah, and then restated at Mount Sinai in conjunction with the Mosaic Law. Whereas the commandments given to Moses at Mount Sinai are incumbent exclusively upon the Jews, the laws given to Adam and Noah are incumbent upon all of humanity at all times. Because of this, Noahides are not Jewish, though Noahidism is a concept that has been developed exclusively by Orthodox rabbinic Judaism. Today's Noahides observe their religion under the tutelage of Orthodox rabbis. 
While the past two millennia of Jewish history have been marred by oppression at the hands of Gentile hosts and neighbors, rabbinic Judaism continued to insist, albeit philosophically and hypothetically, that the Torah ${ }^{2}$ had something constructive to say about the non-Jewish world. The foundation of Noahidism as we have it today was the brain child of rabbinic speculation concerning the goyim (non-Jews), and it played an important role in settling a number of important questions. From a halakhic (Jewish legal) perspective, the Noahide laws are significant because they provide normative values through which Jews and Gentiles may communicate regarding political and social issues, particularly when Jews seek to settle in Gentile lands and vice versa.

Theologically, adherence to these laws are necessary and sufficient for Gentiles to attain spiritual salvation, also known as meriting olam ha-ba (the world to come, or heaven). Philosophically, Noahidism was a system of ethics that could be rationally derived, thus providing a bridge between Judaism and the various intellectual projects of Western rationalism such as the Enlightenment. David Novak, Hermann Cohen, and Moses Mendelssohn are among those Jewish philosophers who have argued that Noahide law is natural law, but this notion has numerous significant halakhic and theological implications that many Orthodox theologians are unwilling to accept. It is however evident that Noahidism has a dynamic and important role in the history of Jewish thought despite its relative obscurity in the study of Judaism or in the life of contemporary Jews.

\footnotetext{
2 The Torah, also known as the Pentateuch or the Five Books of Moses, consists of the books of Genesis, Exodus, Leviticus, Numbers, and Deuteronomy. The Hebrew Scriptures, also referred to as the Tanakh, is the collection of the Torah, the books of the Prophets (Nevi'im), and the books of the Writings (Ketuvim).
} 
Yet history has little to say about Noahidism as a living phenomenon. Indeed it is only over the past 40 years that we find a considerable number of people identifying themselves as adherents to the principles of Noahidism. While still small in comparison to most world religions, Noahidism has members in every continent (bar Antartica) and has gained significant traction in the Orthodox Jewish community due to its theological, halakhic, and eschatological implications within the Jewish worldview. Practitioners and scholars alike are publishing an increasing number of theological, legal, and ethical texts on Noahidism, but little work has been completed on this topic from an academic, religious studies perspective. Thus, whether one sees this as the renaissance of a dormant ancient ethical code, or as the first forays into uncharted terrain, the growth of Noahidism alongside Orthodox Judaism promises to offer interesting vistas.

\section{Objectives}

This thesis surveys the contours of Noahide identity. I aim to understand those values, ideologies, and practices which are central to those people who willingly adhere to the tenets of Noahidism in the contemporary world. Those parties interested in identifying as Noahides may have certain principles or behaviors in common, and in such cases we can agree that these elements form the basis of Noahide identity. But also important are those principles and behaviors that remain contentious among the interested parties. The lines of discourse formed around these points of contention are the frontiers of Noahide identity; they are the conceptual meeting places for individuals currently vying to form their identity in relation to each other and to Orthodox Jewish 
communities. Identity is not simply a matter of examining the practices and values shared by the group, rather, we should discuss identity in terms of "process, movement, flux, change, and conflict." ${ }^{3}$ Perhaps it is more important to recognize that identity, and the things we attribute to it, are inseparable from the context in which they occur ${ }^{4}$-and this undoubtedly includes the context of the observer whose role is to describe this identity.

My work does not treat all of the similarities or dissimilarities among contemporary, English-speaking Noahides. Instead, I investigate how five of the most prevalent factors shape Noahide identity. These factors are 1) Noahide law, 2) contemporary notions of religious pluralism within Noahidism, 3) Noahide ritual, 4) Jewish sectarianism, and 5) conversion to Noahidism and to Orthodox Judaism.

Noahidism as an ideology and identity is concerned most with universal justice and peace, for which law is a vital component. Despite rabbinic insistence that these laws are the lynchpins of human dignity and society since the dawn of time, much is still unclear about the essence of Noahide law. A good amount of debate still rages over the number, content, and scope of the laws; accounts range from seven general categories of law to 66 specific laws. There is also much to be said about the issue of capital punishment in the Noahide code. The violation of any Noahide law is punishable by death - the rabbinic texts are clear about this, but there is still conversation over whether

\footnotetext{
${ }^{3}$ Laurence J. Silberstein and Robert L. Cohn, The Other in Jewish Thought and History: Constructions of Jewish Culture and Identity (New York: New York University Press, 1994), 4.

${ }^{4}$ Ibid., 9.
} 
violations must be punish by death, or whether Noahide communities can implement their own schedules of punishment.

There are also considerable disagreements over the essence of the Noahide laws as a whole; some hold that the Noahide code is a rationally conceivable system of ethics independent of divine revelation, whereas others argue it is only because of revelation that humans are aware of and inspired to observe the laws. I posit that varying perspectives on the laws cause differing attitudes among Noahides regarding ritual, religious exclusivity, and the role of Noahides in Jewish communities.

Although the exact role of Noahides within Jewish communities is still largely undefined, Noahides are generally motivated to see themselves as part of the Orthodox Jewish fold for a number of reasons. Perhaps one of the most important motivations is the biblical prophecy that the Messianic era will see a great number of Gentiles seek the spiritual guidance of Jews. Many Noahides openly profess their belief that they are indeed fulfilling this prophecy today. Such convictions undoubtedly motivate Noahidesand presumably Jews as well — to explore and persevere in the development of a religion for Noahides as well as a relationship with Orthodox Jewish communities.

One of the many obstacles facing a solid relationship between Noahide and Orthodox Jewish communities is the supposedly universal appeal of Noahidism. On the one hand, there is a palpable gravitation among Noahides towards Jewish culture and thought, and yet there is on the other hand the notion within Noahide ideology that Gentiles should or even must maintain their cultural and intellectual traditions while 
being pious to the God of Israel. Balancing these two tendencies is unsurprisingly a tricky business and can lead to conceptual and practical issues. Very often, the rhetorical strategies used to explain Noahidism's universal nature appear to advocate a sort of religious inclusivism or pluralism. These rhetorical schemes in contemporary Noahide literature generally present the Noahide laws as an objective ethical system, even going so far as to deny that Noahidism is a religion.

Some, like contemporary writer Rabbi Michael Bar-Ron, deepen this notion by positing that even atheists are within the letter of the law. Other writers, like Rabbi Shimon David Cowen, argue that the laws of Noah are the foundation of the world's major religions. As we will see later on in the chapter on pluralism, their approaches usually lead, either explicitly or implicitly, to the inference that Noahidism is opposed to religious exclusivism. A careful review of the primary literature, however, reveals that the universal nature of Noahidism is not as broad as contemporary writers claim it to be. I hold that the laws of Noah, as they are portrayed today, clearly describe an exclusive lay religious order of Orthodox Judaism. Religious inclusivism or pluralism are not features of Noahide ideology or practice.

There is also strong evidence to support this assertion when we look at Noahide ritual. As already stated, the varying perspectives on Noahide law influence perspectives on ritual practices. Those who believe the code is essentially negative and general tend to prescribe less ritual activity for Noahides; the more the code is interpreted as positive and specific, the more ritual activity is advocated. Yet rabbinic sources generally accept of the 
idea that Noahides are permitted to observe a majority of the Jewish commandments and rituals so long as they understand they do not observe these practices under the premise that God commanded them to do so. This access to observe Orthodox rituals ties Noahidism intimately to the Orthodox Jewish religion. Separately, a number of philosophical arguments exist in favor of greater ritual activity loosely based on virtue ethics. Yet, the domain of Noahide ritual remains largely obscure. I argue this makes it difficult for Noahides to develop a strong religious identity and sense of community. Conversely, a lack of religious identity and community makes it difficult for ritual to develop.

Because many of the Jewish and Noahide debates regarding law, theology, and ritual are shrouded in the complexities of Talmudic literature, Noahides are often incapable of penetrating these discourses on their own. This tends to create a common need for Noahides to seek association with Orthodox Jewish communities that can provide theological and halakhic guidance and even training. It is therefore not uncommon to see Noahide sectarianism develop along the same lines as Jewish sectarianism. To this end, there are Hasidic Noahides, Karaite Noahides, Yemenite Noahides, and so on. There are, however, Noahide sects that develop along different lines altogether. I argue this occurs because these other Noahide sects allow practitioners to perform a greater number of rituals than other sects.

Without a strong sense of personal or communal religious identity, Noahides are often compelled to take one of three courses: abandon Noahidism, accept a form of 
Noahidism that advocates a greater amount of ritual participation, or seek conversion to Orthodox Judaism. The possibility that Noahidism is a gateway to Orthodox conversion is conceivably a topic for further research, given the large number of people that are currently seeking access to a Jewish identity. ${ }^{5}$ My brief look into this issue may not yield conclusive results, but I make a confident conjecture that Noahidism is not a gateway for conversion to Orthodox Judaism.

\section{Methodology}

The initial scope of this thesis sought to integrate substantial ethnographic work, quantitative data, and a thorough analysis of primary Noahide literature written in English. Unfortunately, the scope of this work was limited by a shortage of time and resources. Additionally, it is the nature of master's level work to be narrowly focused another pressure to which my research ultimately had to succumb. The kind of project I envisioned is too far-reaching and better suited for doctoral research.

As a result, the ethnographic component of this research has been abandoned, although remnants of it can be found occasionally throughout the thesis. This data are, however, nothing more than supplementary to the other points being made throughout. My research relies on an analysis of two genres of literature regarding Noahidism. I will describe these genres in the following chapter. While a number of the dialogues and debates concerning Noahidism are grounded in rabbinic texts and Scripture, my analysis

\footnotetext{
${ }^{5}$ Here one might think of the Igbo tribe of Nigeria, the tribe of Manasheh in India, the conversos scattered around Latin America, and other groups vying for Jewish identity.
} 
focuses not on interpreting these texts, but rather on interpreting the rhetoric of contemporary Noahidism.

Additionally, a 33-item questionnaire was disseminated through qualtrics.com to Noahide practitioners. This survey collected data from more than 250 respondents regarding their demographic information, relationship with Jewish communities, relationship with Noahide communities, personal religious practices/preferences, and personal religious history.

\section{Other}

This text is not primarily prescriptive, that is, I do not make value judgments on the ideas and practices of Noahides and of those involved with the movement. My business is not to suggest what Noahides should believe, but rather, I intend to describe what Noahides do believe. Some of my analysis sheds light on possible issues regarding Noahide ideology or ritual. In some of these cases, I point out conceptual contradictions or pitfalls, but that is not to suggest Noahidism is an invalid belief system. Like any religious tradition in recorded history, conceptual issues in their theological and philosophical foundation and superstructure take time to resolve, and this is no different with contemporary Noahidism. If at some points I am driven to be prescriptive or confrontational, I do my best to warn the reader and to point out to what extent my prescriptions verge on speculation.

It is also important to recognize there are today a variety of Noahidisms. As a descriptive work, it is my intention to explore these variations without holding any one of 
them in favor over another. As such, I make no attempts to evaluate which is the authentic Noahidism, nor do I strive to determine which variation resonates most with Hebrew Scripture or Orthodox Judaism.

Lastly, I have to reiterate that this work is not a comprehensive one. As a master's thesis, it is meant to be a project of narrow scope, so the task of capturing the totality of contemporary Noahidism in all of its various literary, electronic, and living forms is simply impossible. 


\section{CHAPTER 1}

\section{LITERATURE REVIEW}

\section{What are the Noahide Laws?}

The primary literature regarding the laws of Noah and Noahidism can be broken down into a number of distinct genres. There is first the Biblical and extra-Biblical literature, which serves as the original source of Noahide theology, philosophy, and practice. This corpus is comprised primarily of the Tosefta, ${ }^{6}$ the Mishnah, ${ }^{7}$ the Talmud, ${ }^{8}$ the Hebrew Scriptures, and a variety of other rabbinic texts that are often consulted by contemporary writers when composing halakhic and theological guides to Noahidism. These contemporary guides make up the second genre of the primary literature; they are typically written by rabbis although unordained Jews and Noahides have contributed as well. This body of work provides contemporary Noahides with practical interpretations and applications of Noahide law while also clarifying the more nuanced theological and philosophical aspects of the code.

The culmination of these halakhic and theological guides has been a steadily growing body of liturgical materials to serve the spiritual needs of the growing Noahide population. Some Noahides have also produced autobiographical works which account

\footnotetext{
${ }^{6}$ The Tosefta is a compilation of oral Jewish law written in the late second century C.E. as a supplement the Mishnah.

${ }^{7}$ The Mishnah was the first major, authoritative compilation of oral Jewish law written in third century C.E.

${ }^{8}$ The Talmud is the body of writing containing the Mishnah and the Gemara (c. 500 C.E.). The Gemara is rabbinical commentary to the Mishnah. There are two distinct Talmuds: the Babylonian Talmud and the Palestinian Talmud, named after the places in which they were compiled.
} 
for their personal spiritual journeys to Noahidism. Their accounts cannot be taken to speak for the general Noahide population, but it is instructive that the occasion for their writing is not merely reflective, but actually meant to guide others on similar spiritual journeys.

Although the Noahide laws are considered to be derived from the Jewish tradition, anyone looking for an explicit mention of these laws in the Jewish Scriptures will be disappointed. The only commandments explicitly mentioned in the Scriptures are found in Genesis 9:3-4 and Genesis 9:6. Verses 3-4 prohibit the consumption of a torn limb from a living animal, stating that "Every moving thing that lives shall be food for you; like the green herbage I have given you everything. But flesh[,] with its soul its blood you shall not eat." "Verse 6 prohibits murder, saying that "Whoever sheds the blood of man, by man shall his blood be shed; for in the image of God He made man."10

The most commonly cited rendition of the seven commandments can be found in the Babylonian Talmud, where it reads that "Seven precepts were the sons of Noah commanded: social laws; to refrain from blasphemy; idolatry; adultery; bloodshed; robbery; and eating flesh cut from a living animal."11 The earliest rendition in our possession is found in the Tosefta, which dates to around the second century C.E. The list

\footnotetext{
${ }^{9}$ Nosson Scherman, The Chumash: The Torah, Haftaros and Five Megillos, Stone ed. (Brooklyn, NY: Mesorah Publications, 2012), 41.

${ }^{10}$ Ibid., 41.

${ }^{11}$ Schachter, Jacob, H. Freedman, and Rabbi Dr. I Epstein. The Babylonian Talmud: Seder Nezikin: Tractate Sanhedrin, http://halakhah.com/sanhedrin/index.html, Folio 56A.
} 
in the Tosefta is similar to the list in the Babylonian Talmud, except that the prohibitions of blasphemy and idolatry have switched positions. ${ }^{12}$

The Talmud elaborates upon these laws and claims they are embedded in Genesis 2:16, where it is written that "Hashem ${ }^{13}$ God commanded the man, saying, 'Of every tree of the garden you may freely eat." ${ }^{\prime 14}$ Of course this verse makes no explicit mention of any Noahide law, but the Talmud maintains that the exegesis of this sentence yields the seven precepts. The argument goes that certain words in the sentence refer to other passages from which the prohibitions can be inferred. The validity of this verse as the proof text for the Noahide laws has been questioned, particularly by Rabbi Judah Halevi who believes that the sentence acts only as a mnemonic device, that is, an aid to memorize the seven laws. ${ }^{15}$ It is not, he argues, the actual source of the laws.

It is also worth mentioning that the Talmud records Tannaitic ${ }^{16}$ rabbis who argued over the precise number and content of the laws incumbent upon humanity. In addition to the seven laws, we can also find rabbinic opinions "not to partake of the blood drawn from a living animal...emasculation... sorcery...the forbidden mixture [in plants and animals]...they are forbidden only to hybridize heterogenous animals and graft trees of

\footnotetext{
${ }^{12}$ David Novak and Matthew Lagrone, The Image of the Non-Jew in Judaism, 2nd ed (Portland, OR: Littman Library of Jewish Civilization, 2011), 11.

13 "Hashem" is a Hebrew word used to refer to God. Its literal translation is "the name."

${ }^{14}$ Scherman, The Chumash, 13.

${ }^{15}$ Novak and Lagrone, Non-Jew in Judaism, 17. Also see David Novak, Natural Law in Judaism (New York: Cambridge University Press, 1998),151. The Hebrew word which refers to this method is asmakhta.

${ }^{16}$ The word "tannaitic" refers to a period roughly between the first and third centuries C.E. In this case, it refers to rabbis who lived during that period.
} 
different kinds. ${ }^{\prime 17}$ Non-canonical sources present an even greater variation of laws. In Jubilees 7:20-21, it is recorded that "Noah began to enjoin upon his sons' sons the ordinances and commandments, and all the judgments that he knew, and he exhorted his sons to observe righteousness, and to cover the shame of their flesh, and to bless their Creator, and honour father and mother, and love their neighbour, and guard their souls from fornication and uncleanness and all iniquity." 18 David Novak notes that although a number of variations regarding the content and number of laws can be found in the extraBiblical literature, there is no explicit rejection of the principle of Noahide law in general. $^{19}$

The precise historical origin of the Noahide code cannot be determined at the moment, although a number of theories have been put forth by numerous scholars. One such theory posits that the Noahide laws have their source in the biblical period, citing the widespread use of similar laws in the codes of various near and middle eastern legal systems. Proponents of this theory argue that the other codes represent variants of the Noahide law which were altered and corrupted by polytheistic and self-serving rulers. The Jewish tradition, by contrast, maintained the original set of laws. The momentum of such an argument is certainly attractive to Jewish thinkers and apologists, but its soundness is questionable. Advocates of this theory arbitrarily choose the Noahide laws as standard against which to judge all other similar legal codes. In other words, there is

\footnotetext{
${ }^{17}$ Schachter et al., Sanhedrin, Folio 56b.

${ }^{18}$ Robert Henry Charles, The Apocrypha and Pseudepigrapha of the Old Testament in English (Oxford: At the Clarendon Press, 1913).

${ }^{19}$ Novak and Lagrone, Non-Jew in Judaism, 13.
} 
no reason why one should not choose Hamurrabi's code as the uncorrupted version against which to judge all other similar but variant legal codes. No evidence compels scholars to accept the Noahide law as the original source for cognate legal codices. ${ }^{20}$ Another theory posits that Hittite ${ }^{21}$ law might be the source for Noahide law, given the sense of normativity with which rabbis treated the Hittite legal code. This theory is also far-fetched in that any sources referring to the normative nature of Hittite law were edited long after the Gemara provided the version of the Noahide code we have seen above. ${ }^{22}$ The Maccabean period ${ }^{23}$ is also cited as the historical origin of the Noahide laws. This period marked the first time in four centuries that Jews were sovereigns in their own land. The new rulers also had to deal with a large non-Jewish population living within their borders. Because the book of Jubilees is a work contemporary to the Maccabean period, proponents of this theory cite Jubilees 7:20 (seen above) as evidence that the Jewish elite created Noahide laws as a way to maintain order among such a large non-Jewish population. ${ }^{24} \mathrm{~A}$ close reading demonstrates nothing of the sort however. Instead, Jubilees 7:20 merely indicates that non-Jews and the Patriarchs had observed aspects of the Mosaic law long before its promulgation at Sinai. More importantly, historical records of that period demonstrate that Jewish rulers pressed Gentiles to

\footnotetext{
${ }^{20}$ Ibid., 13-5.

${ }^{21}$ The Hittites were a group of people who established an empire in Anatolia (central and eastern Turkey) around 1600 B.C.E.

${ }^{22}$ Ibid., 16.

${ }^{23}$ The Maccabean period is considered to run from 167 B.C.E. - 160 B.C.E.

${ }^{24}$ Ibid., 17.
} 
convert and accept Jewish law in its fullness, meaning that there was no political or social space allotted for Gentiles to retain their non-Jewish identities..$^{25}$

Yet another theory places the origin of Noahide law in the context of Hellenistic Judaism. Jews living in the Hellenistic world referred to a particular group as "fearers of the Lord." These were Gentiles who increasingly adopted Jewish customs without completing conversion. Some scholars believe the laws of Noah were created during this time in order to provide structure for these people. The laws helped mediate which nonJews could interact with the Jewish community; it set a minimal standard of ethical comportment for Jewish-Gentile religious interaction. Ideal as it sounds, this argument also has several issues. Many groups of Hellenistic Jews tended to practice gradual conversion. This process allowed fearers to observe more commandments over time if they proved faithful and careful to the details of the mitzvot (Jewish commandments). Prospective converts progressively assumed more ritual responsibility based on their ability to correctly observe the commandments. If these individuals demonstrated their dedication to the Mosaic laws over an extended period of time, they were fully included into the Jewish community. But the rabbinic notion of Noahide law presented in the Talmud offered "a precise distinction between Jews and Gentiles rather than a mere difference in degree." ${ }^{26}$ This means that the Noahide laws could not be used in a gradual process like the one administered to the feared of the Lord. We also note how the Gemara presents the Noahide code as being strictly negative in nature (“...concerning the seven

\footnotetext{
${ }^{25}$ Ibid., 18-9.

${ }^{26}$ Ibid., 28.
} 
commandments they are thought of as 'sit and do nothing" ${ }^{27}$ ), meaning that the enforcement of the Noahide law most likely would not have simultaneously permitted the observance of Jewish ritual by Gentiles. Similarly, the institution of the ger toshav (resident alien ${ }^{28}$ ) may not be the source of the Noahide laws because the category of resident alien long predates the Noahide code according to textual evidence. ${ }^{29}$

The last substantial attempt to locate the historical origin of the Noahide code is put forth by David Novak, who argues that no evidence can firmly place the code to an earlier date than the Tannaitic period. This period is not only textually corroborated, but there also seems to have been a number of similar projects occurring at that time. The rabbis of this period discussed which laws were required by reason even if they were not found in Scripture - a discussion which mentions five of the seven Noahide laws. In a similar vein, rabbis were also attempting to identify those laws which are utterly indispensable for the Jew. Both of these lines of inquiry resemble the concerns of the Noahide code, but with respect to Jews and not Noahides.

Novak does account for the fact that many pre-Sinaitic characters in the Torah are held accountable for transgressions, perhaps suggesting that the Noahide laws are indeed as ancient as the rabbis maintain (how could these characters be guilty of something when there was no prohibition?), but he is unwillingly to accept this position without further historical evidence.

\footnotetext{
${ }^{27}$ Ibid., 29.

${ }^{28}$ This concept permitted non-Jews to live in Jewish lands.

${ }^{29}$ Ibid., 20-3.
} 


\section{Applications of Noahide Law}

What records we do have of Noahide law reveal that this conceptual framework has enjoyed a good amount of application despite its relative obscurity in the field of Jewish studies and in the mainstream Orthodox Jewish world at present. These applications can be found in two genres of literature, namely theories of religious pluralism and inclusivism as well as political and legal philosophy. The latter is far more robust and it is where we will begin our review.

The fields of political and legal philosophy have been key in the process of Jewish self-understanding during the medieval and modern eras. In the medieval era, the nuances of Jewish exile required that both Christians and Jews alike develop a conceptual framework through which to justify the special relationship between Christian lords and their Jewish subjects. From the Christian perspective, the exiles maintained a second class status that provided the dual benefit of oppressing them while also making them eligible to carry out functions considered unclean for Christian souls - in particular, usury. This was not, of course, categorically true in all parts of Europe where exiled Jews dwelt. In Spain, for example, the so-called convivencia permitted Jews to exercise a degree of autonomy under the supervision of their Muslim rulers. Nonetheless, even Spanish Jews sought out a halakhic framework to guide Jewish-Gentile relationships.

Whereas the philosophical speculation of the medieval period sought to legitimize the political relationships between Jew and Gentile, the focus of the modern period was to do away with the political nature of Judaism. This change of course was a 
conscientious response to the philosophical and political innovations of the European Enlightenment, among which were included the separation of church and state. The efforts of many modern Jewish thinkers, particularly in the German states, focused on demonstrating that Judaism was in essence a religion-in the Protestant sense of the word $^{30}$ — and not a socio-political entity however much the Torah may refer to the "people" or "nation of Israel." The purpose of this endeavor was not merely academic or speculative, but rather aimed at acquiring greater civil, social, and economic rights for the Jewish residents of western European nations.

If the Jewish tradition was mostly socio-political in nature, then Jewish residents would have a weaker commitment to (and possibly contradict) the socio-political aims of the host nation-state. This was frequently the reason why European governments would withhold civil and economic rights from Jewish residents. To put it inversely, ff these Jewish thinkers could demonstrate that Judaism was a religion internalized by the individual for their spiritual and moral refinement—and not a socio-political entity — then Jewish residents could freely and strongly identify with the socio-political aims of their respective nation-state.

In summation, the medieval project aimed at developing an ideology which maintained the political and ethical integrity of Judaism while making for peaceful cohabitation between Jews and Gentiles in Europe. In this context, the political qualities of Judaism were emphasized. With the eventual separation of church and state and the

\footnotetext{
${ }^{30}$ This definition of religion stresses the individual's personal and direct relationship with the Divine. This relationship is one of feeling as opposed to one of contemplation or communal unity. It is strictly apolitical, meaning that modern Jewish thinkers needed to demonstrate that Judaism was similarly apolitical.
} 
prospect of political integration, Jewish thinkers sought to dissolve the political and ethical boundaries previously established. They conspired to paint Judaism as a purely individualistic religion. Interestingly, the medieval and modern projects, despite their contradictory aims, utilized the laws of Noah as the foundation of their philosophical arguments. ${ }^{31}$

The Noahide code served both projects as a way to reflect about the nature of the Gentile world, and thus provided a foundation for Jewish self-understanding. For the medieval Jewish thinkers, the laws of Noah provided a minimal legal standard against which Gentile legal systems could be analyzed. If rabbinic authorities believed a Gentile community and its laws met this minimal standard, then the community was considered suitable of Jewish habitation during their exile from Eretz Yisrael (the land of Israel). The laws of Noah also provided a conceptual backdrop against which to measure the validity of rabbinic innovations in the context of exile communities, where Gentile legal principles had to be kept in mind and respected.

Modern Jewish thinkers, on the other hand, sought to shed Judaism's political garb and bring its religious, non-political dimension to the fore. They viewed Noahide laws not as a political framework, but as an ethical system that points to Judaism's ultimate concern with the moral life of the individual. Whereas the Mosaic code of law is particularistic and therefore indicative of a distinct socio-political telos, the Noahide code

\footnotetext{
${ }^{31}$ Leora Faye Batnitzky, How Judaism became a religion: an introduction to modern Jewish thought (Princeton, NJ: Princeton University Press, 2011).

Batnitzky's work provides a detailed historical account of the medieval and Enlightenment era projects carried out by Jewish intellectuals I have discussed here.
} 
was presented by these thinkers as universal. It was the universal nature of the Noahide code that indicated, as the argument goes, the Divine's supreme regard for the spiritual salvation of all mankind.

The medieval project was carried along by thinkers like Maimonides, Joseph Albo, and Menachem ha-Meiri, although a great amount of disputation and innovation can be attributed to numerous Talmudic scholars. ${ }^{32}$ The modern project of disassociating Judaism from its legal-political traditions was carried out by many Jewish thinkers such as Heinrich Graetz, Samson Raphael Hirsch, Abraham Geiger, Hermann Cohen, and Moses Mendelssohn. Yet it is the latter two that engage the Noahide code as a substantial issue of their philosophical arguments. ${ }^{33}$

Moses Mendelssohn, for example, saw Mosaic law as pertaining to what he called historical truths, that is, truths which are manifest in time as events. The Noahide laws can be categorized as either contingent or universal truths because their prescriptions relate to the order of the created universe prior to the passage of time. The implication here is that Noahide law is in fact superior to Mosaic law, or rather, "Judaism becomes an element within a universal religion of metaphysics [the Noahide code]"34_ no doubt a surprise to Gentile intellectuals of his time. But more importantly, one can see from this example Mendelssohn's goal of relegating Judaism to a cultural and personal

\footnotetext{
32 See Novak and Lagrone, Non-Jew in Judaism, for a detailed analysis of each Noahide law and their socio-political implications of their Talmudic exploration.

${ }^{33}$ See Batnitzky, How Judaism Became a Religion, for thorough analysis of the philosophical arguments utilized by Jewish thinkers in the modern era to argue for Judaism's status as a religion and not a sociopolitical unity.

${ }^{34}$ Novak and Lagrone, Non-Jew in Judaism, 211.
} 
phenomenon below the greater universal, philosophical allure of the Noahide code. The preeminence of the Noahide code in the Jewish religion was for Mendelssohn and his school an indication that Judaism was chiefly concerned with universal ethics and, as such, merited a respected place in modern society.

It is from the modern and pre-modern intellectual projects that we also find the notion of the Noahide code as a Jewish version of natural law. This is a position we find today clarified and expounded by David Novak. From his analysis, he concludes that Noahide law represents a "moral category separate from revelation" that aims to unite humans in a common moral truth based on the "foundations of inter-human relations and the elementary moral standards that make interaction possible and desirable." 35 Various other contemporary academic texts explore the application of Noahide law to various legal and philosophical problems, ranging from the concept of justice and jurisdiction ${ }^{36}$ to the nature of the Mosaic code, ${ }^{37}$ and immigration. ${ }^{38}$

I mentioned at the beginning of this chapter that the laws of Noah also feature in various accounts of religious pluralism advocated by Jewish writers, but it should be noted that the Noahide code does not form the foundation of these accounts. Dan CohnSherbok, for example, bases his argument in Kantian metaphysics-because human

\footnotetext{
35 Ibid., 231-33.

${ }^{36}$ Nahum Rakover, "Jewish Law and the Noahide Obligation to Preserve Social Order," Cardozo L. Rev. 12 (1990): 1073 .

37 Stone, Suzanne Last, "Sinaitic and Noahide Law: Legal Pluralism in Jewish Law," Cardozo L. Rev. 12 (1990): 1157.

${ }^{38}$ Gidon Rothstein, "Involuntary Particularism: What the Noahide Laws Tell Us About Citizenship and Alienage," Geo. Immigr. LJ 18 (2003): 543.
} 
perception is limited, we cannot know the "thing in itself," thus we cannot claim to have absolute knowledge of religious truths, which implies that Judaism and every religion must accept the truth claims of all other religions. ${ }^{39}$ In his work, the laws of Noah act as the conceptual framework that accommodates Gentiles within the Jewish worldview, and also as a suggestion that religious pluralism has been a feature of Jewish tradition for some time.

\section{Understanding the Living Noahide Movement}

In contrast to the academic literature on the legal and philosophical import of the Noahide laws, rather little work has been conducted on the laws of Noah as embodied and lived by individuals throughout history. In fact only two academic works describe the living Noahide movement.

Written by Jeffrey Kaplan, Radical Religion in America provides a brief sketch of the Noahide movement in the context of its relationship with millenarian movements, particularly those of the far American right. While this focus does shape Kaplan's analysis, his work can still be read as a detailed understanding of Noahidism as a lived identity. His chapter on Noahidism provides a substantial account of the movement's history as a living tradition, beginning with a group of Christian Noahides guided by Rabbi Elijah Benamozegh in Italy during the 19th century. The emergence of the current Noahide movement is traced to the 1970s when a man by the name of Vendyl Jones began collaborating with Baptist minister J. David Davis in their exploration of the

\footnotetext{
${ }^{39}$ Dan Cohn-Sherbok, Judaims and Other Faiths (New York: St. Martin's Press, 1994), 168-169.
} 
historical Jesus. This eventually led to the First Annual International Conference of the B'nai Noah (children of Noah) at Fort Worth, Texas during April of 1990. The Noahide movement gained a substantial amount of legitimacy after receiving blessings from the Chief Sephardi Rabbi of Israel, Mordechai Eliahu, which then prompted a close alliance with the Temple Institute of Jerusalem. This was accompanied by an interview on Larry King Live, a Wall Street Journal article, and various other opportunities to publicize the movement, all which were met with as much contempt from detractors as excitement by others who were seeking closer ties to the Orthodox Jewish tradition.

Kaplan's analysis also brings out many of the tensions discussed in my thesis. At one point he discusses the sectarian fault lines among Noahides that are modeled largely after Jewish sectarianism. He also brings out the perceived inequality of punishment meted out by the Noahide and Mosaic laws for the same transgressions. In contrasting the Noahide movement with right wing American millenarian movements, Kaplan notes the Noahide movement is unusually messianic or at the very least eschatological in its outlook. This is due to the portents in Jewish Scripture which speak of Gentiles who flock to Jewish cities to seek Jewish spiritual guidance. ${ }^{40}$ Like Novak, Kaplan also notes the lack of historical evidence that Noahide law has ever been implemented on a political basis, or that communities have consciously observed its precepts for religious or ethical reasons. ${ }^{41}$

\footnotetext{
40 Jeffrey Kaplan, Radical religion in America: millenarian movements from the far right to the children of Noah (Syracuse: Syracuse University Press, 1997), 106.

${ }^{41}$ Ibid., 109.
} 
A more thorough analysis of Noahidism as an active religious movement is found in Birgit Vollmar's Noahs Kinder. ${ }^{42}$ Whereas Kaplan's analysis pushes the 30 -page count, Vollmar's work — a master's thesis published only in German—runs to about 500 pages and has been published as the most extensive account of contemporary Noahidism. Her work explores the theological and philosophical roots of Noahidism before giving a detailed description of the movement's contemporary history. She also prepared a questionnaire for Noahides with a sample of about 50 respondents. Vollmar's survey is not used as a foundation for the survey I have conducted here, although comparative analysis would hopefully yield some insights. What is unique about Vollmar's approach is not only that it strives to be comprehensive, but that it also attempts to understand Noahidism on its own terms, as opposed to Kaplan's work which is colored by the concern with radical religion and violence in the United States.

${ }^{42}$ Birgit Vollmar, Noahs Kinder: Die Glaubensbewegung der Noachiden in der Gegenwart (Tectum Verlag, 2012). 


\section{CHAPTER 2}

\section{IDENTITY AND THE LAWS OF NOAH}

As the literature (both academic and primary) suggests, Noahidism is focused on observance of the Noahide laws, whether in a legal or ethical context. The interpretation of these laws has significant practical, philosophical, and theological implications that shape contemporary Noahidism. In this chapter we explore various tensions within Noahide law and how they might impact Noahide identity.

\section{The Code as a Body of Negative Law}

The Noahide code as we find it in the earliest Talmudic iterations is characterized as a negative body of law. It asks Gentiles to abstain from certain behavior, but does not command them to perform any actions. As we have already seen, the earliest rabbinic sources characterized it as "sit and do nothing." 43 And although one law (the requirement to establish courts of law) is positive, some commentators attempt to reinterpret the requirement to establish courts as negative, so as to show that the code is ultimately negative in nature:

The commandment to establish courts of law, though it might appear to be a positive commandment calling for affirmative action, is considered a prohibition. In effect, the commandment to establish courts of law is a prohibition against failing to establish courts of law, because failure to establish appropriate courts inhibits the performance of justice through out the nations. ${ }^{44}$

\footnotetext{
43 Novak and Lagrone, Non-Jew in Judaism, 29.

44 Chaim Clorfene and Yakov Rogalsky, "Introduction to the Noahide Laws." Noahide - The Ancient Path, Last modified May 22, 2011, Accessed October 5, 2014, noahide-ancient-path.co.uk/index.php/judaismarticles/2011/05/the-path-of-the-righteous-gentile/, Ch 12, Part 1, Point 2.
} 
Rakover reinforces the negative aspect of the code while exploring this same law (referred to as law of din in Hebrew), suggesting that Noahides are not required to fulfill any positive commandment. To this effect, he cites Nahmanides who notes that Gentile judges are allowed to withdraw from cases on a whim, whereas Jewish judges must wait to hear the evidence of the litigants before deciding to withdraw for reasons of bias or incompetence. Nahmanides concludes that if a Gentile judge is allowed to withdraw from any lawsuit, the average Gentile should not be required to enforce the Noahide laws on their own accord. Even if the requirement to establish courts of law is a positive one, Noahides are not expected to be proactive or act positively - the implication being that Noahides have no duty to act positively in any context since they are exempt from acting positively in the one case in which we would expect a Gentile to be proactive. ${ }^{45}$ Nahmanides' opinion is not conclusively binding on Noahide law, nonetheless it demonstrates a long-standing awareness of the Noahide code as a corpus of negative laws.

Others have attempted to nuance their understanding of the code's negative nature and have produced valuable insights. Suzanne Stone's analysis suggests a correspondence between the negativity of the Noahide code and its objectives. She compares this correspondence with the positive nature of the Mosaic code and its respective telos. The Jewish system of law, according to Stone, is a system of exceptional leniency to the accused that reflects certain assumptions about both the privileges granted by God with the election of

\footnotetext{
${ }^{45}$ Rakover, Noahide Obligation, 1124.
} 
the Jews at Sinai and the nature of divine justice that Jews are commanded to emulate. The two judicial systems are logical outgrowths of the different goals of the two legal Codes. The Noahide Code addresses the obligations of members of social communities and sets forth how such communities may achieve a moral political life; the Sinaitic Code addresses the obligations of a covenantal community. ${ }^{46}$

In short, laws which govern the relationships between individual Jews are special because the Jewish relationship with God is special. The Gentiles, on the other hand, do not have this special relationship with the Divine, and so they are held to a different standard of behavior. We can perhaps trace this notion scripturally to God's repeated exhortations: "you shall sanctify yourselves and you will be holy, for I am holy." ${ }^{47}$ Stone cites R. Nissim of Gerona on this point, who states that "The Torah's judicial model judges the people in accordance with that which is ideally just in itself, whether or not this suits the needs of society. .."48 The Jews have been imbued with the very standards of justice the Divine would employ, but Noahide law is at a remove from this maximum standard of justice. If Stone and R. Nissim are correct in their analysis, it would show that the negative nature of the Noahide laws is not arbitrary; the negativity of Gentile code is indicative of a lower moral standard than Jewish law.

While Noahide law is concerned primarily with socio-political peace, it is not useless in Jewish self-understanding. Stone echoes one of David Novak's arguments that the Noahide laws were employed as a sort of philosophical backdrop against which to

\footnotetext{
46 Stone, Sinaitic and Noahide Law, 1159.

${ }^{47}$ Lev. 11:44. (Scherman, The Chumash, 607).

${ }^{48}$ Stone, Sinaitic and Noahide Law, 1194.
} 
evaluate certain aspects of Jewish practice. She writes that "the Talmud and later responsa [were used] as part of an intricate process of identifying those aspects of the Sinaitic Code that further particular aspirational goals of the Jewish community (such as to be 'holy') but are not necessary for creating a moral political community." ${ }^{49}$ To be precise, the Noahide and Sinaitic codes are both concerned with social justice, but the latter goes further and elevates the spiritual condition of the Jewish people. Identifying the differences between the two codes reveals the ultimate aim of Jewish life.

Although we can find a good amount of evidence to argue for the negativity of the Noahide code from a legal and philosophical perspective, the religious implications of this feature have more significant consequences for contemporary Noahidism that are generally undesirable for many, if not most of today's Noahide practitioners. We will not explore this point in great detail here, but it is important to recognize that the negativity of the Code precludes Noahides from mandatory participation in ritual activities (see the chapter on Identity and Noahide Ritual). Indeed there are Jewish laws that explicitly prohibit the creation of Noahide ritual. The ritual poverty of the Noahide tradition has become a significant issue for faithful B'nei Noach who feel their spiritual life is empty or stagnant. To circumvent this problem of ritual, a great amount of rhetorical creativity is invoked in contemporary Noahide literature to create a new conception of ritual. This is helpful, although other authors take another tack and develop a new conception of law which inverts the negativity into positivity.

${ }^{49}$ Ibid., 1192. 
So while Rabbi Shimon Dovid Cowen agrees the Noahide laws are "associated with the allaying of conflict," 50 he is simultaneously convinced there is also a positive aspect to the Code as a whole. He observes "there is a sense in which, not simply negatively — as opposing disorder — but positively, the Noahide laws are intended to implant peace in the world." 51 Adherence to these laws does not merely erase murder, theft, and animal cruelty, but they ensure the manifestation of a "practical, harmonious habitation of the world." 52 This sudden reversal from negative to positive is not intended to make the Noahide laws themselves positive, but rather to see in them an essence which prescribes or suggests the possibility that Noahide practitioners may take positive action in shaping their social, political, and religious life.

\section{Legislative and Judicial Power}

This rhetorical shift in the characterization of Noahide law from negative to positive is largely based on philosophical analysis of the Code. This philosophical approach does have its advocates and, as we will see in the chapter on ritual, is invoked quite often in many different ways. Perhaps more surprising, however, is that this shift has halakhic support. The Noahide laws in their Talmudic formulation are undoubtedly negative, but like any legal system, the specific application of each individual law must be clarified. So if we are prohibited from theft, we must determine just what "theft"

\footnotetext{
${ }^{50}$ Shimon Dovid Cowen, The Theory and Practice of Universal Ethics: The Noahide Laws (New York: Institute for Judaism and Civilization, 2014), 46.

${ }^{51}$ Ibid., 47.

${ }^{52}$ Ibid., 146.
} 
means. It is through the elaboration of the Noahide laws that positivity finds space to set roots. A variety of schema exist for the elaboration of Noahide law, all of which are speculative at best. That is to say, the contemporary enterprise of clarifying Noahide legal obligations and rights has led to a great amount of experimentation which is still being debated. There is no foreseeable consensus among Noahides regarding the expansion of Noahide law. For example, one text presents 130 precepts that inform the prohibition of idolatry and then goes on to prescribe 13 precepts for the law of murder. ${ }^{53}$ Other elaborations are more simplistic, suggesting that Noahides take the general prohibitions and expand on them as they see fit.

How these various positions are derived is the concern of this section. These contemporary halakhic projects are theologically grounded in a common theme, namely the revelation at Mount Sinai. Rabbinic texts claim that the seven laws were given to Adam in the garden of Eden, to Noah at the recession of the Flood waters, and to the Jewish people at Mount Sinai prior to receiving the Mosaic Code. What is more, the Seven Laws (some claim the entire Torah) were presented to and rejected by every nation of the world prior to the revelation at Sinai. ${ }^{54}$ God therefore "commanded Moses and his people to teach them [Gentiles] how. It was both the establishment of a new covenant and the strengthening of the old one." ${ }_{55}$ Gentile rejection of the Noahide Code prior to Sinai

\footnotetext{
${ }^{53}$ Clorfene and Rogalsky, Introduction to the Noahide Laws, Chapters 6 and 8.

54 Stone, Sinaitic and Noahide Law, 1170.

${ }^{55}$ Clorfene and Rogalsky, Introduction to the Noahide Laws, Chapter 2.
} 
gave Israel alone the duty and authority to promulgate the Noahide laws. ${ }^{56}$ The same revelation at Sinai then forms the conceptual framework through which to explore the scope of the Noahide code, and it is in this way that rabbis today are capable of expanding the seven laws into numerous other specific requirements.

Perhaps the first point to understand here is that the Siniatic dispensation serves as the final codification of the Noahide law. Indeed any law given before Sinai, but not repeated to Moses, is abrogated. An example of this is the wasting of seed. It has been asked whether the prohibition of illicit sexual relations includes a prohibition on masturbation or the spilling of semen in cases of sexual activity. Rabbi Cowen's analysis of this prohibition hinges on his understanding of the Sinaitic principle of abrogation. There can only be a specific prohibition on masturbation if there is a specific requirement for man to procreate. Although one such positive commandment can be found in the Torah ("God blessed Noah and his sons, and He said to them, 'Be fruitful and multiply and fill the land""57), it was not repeated at Sinai and therefore is not in effect. The result of course is that the prohibition on wasting the seed is similarly not in effect after Sinai. ${ }^{58}$ More significantly, however, are the possible implications of the simultaneous iteration of the Noahide and Mosaic codes. Those who intend to expand the scope of

\footnotetext{
${ }^{56}$ A variety of explanations for the iteration at Sinai and abrogation of authority exist, as accounted for by Stone in The Sinaitic and Noahide Law. One example claims that only a prophet of Moses' caliber could be entrusted with proclaiming binding legislation, whereas Adam and Noah could only be trusted to live it themselves. Another example states that because the Gentile nations failed to uphold th Noahide code, it required a new iteration, lest it be lost forever (Stone, The Sinaitic and Noahide Law, 1169).

${ }^{57}$ Scherman, The Chumash, 41, Gen 9:1.

${ }^{58}$ Clorfene and Rogalsky, Introduction to the Noahide Laws, Chapter 8, Point 13. Also see Cowen, Universal Ethics, 240 for an opposing view.
} 
Noahide law point to this feature as evidence that there exists a relationship between those specific Mosaic laws which closely resemble the more general Noahide laws. ${ }^{59}$ As Cowen puts it, "One view understands the seven Noahide laws as seven unique detailed prescriptions, which are different to the other 613 commandments of the revelation at Sinai." ${ }^{\circ 0}$ He continues, saying, "The second view is that the seven Noahide laws are in fact classes of laws, subsuming numbers of the 613 commandments given to the Jewish people, often largely in the entirety of their detail." ${ }^{\prime 61}$ The difference between these two perspectives provides two different minimal standards of law and ethics to be met by Noahides. The implications of this disagreement should not be underestimated; it lends itself to a number of practical concerns that may greatly influence Noahide observance in the future.

The result of this debate would essentially determine the degree to which Noahide communities may exercise their legislative and judicial sovereignty — in other terms, the extent to which Noahide communities must interact and collaborate with Jewish communities and institutions. If the Noahide laws are upheld as specific commandments independent of the Mosaic statutes, then Noahides would be granted considerable leeway

\footnotetext{
59 Cowen, Universal Ethics, 148.

60 Ibid., 148.

Cowen notes this position has been advocated by Rabbi Menachem M. Schneerson in Irggerot Kodesh (NY:Kehot), Vol. 1, letter 140, pp. 261-2.

Also see Clorfene and Rogalsky, Introduction to the Noahide Laws, Chapter 12, Point 6.

${ }^{61}$ Cowen, Universal Ethics, 149.

In support of this position, Cowen cites Rabbi Moshe Weiner who in turn cites Moses Maimonides. whose defense of this view can be found at the end of Shoresh 14 in his commentary of Sefer HaMitzvot. Cowen also cites a contemporary source: Rabbi Aaron Lichtenstein, The Seven Laws of Noah (NY: The Rabbi Jacob Joseph Press, 1981), 19-20.
} 
in legislating the specifics of their legal code and in judging their cases according to their own standards. If the Noahide laws subsume the Mosaic commandments, then Noahide sovereignty is greatly limited and interaction with Jewish entities increased. ${ }^{62}$ Which view may predominate is still uncertain and is sure to be influenced by varying commitments to different rabbinic texts as well as the desire of Noahides and Jews to shape Noahidism into a kind of Judaism-lite. It is hard to tell just how strong this desire may be among Noahides, but the rest of this thesis may help readers form an opinion on the matter.

This debate over legislative power has been carried out over a long period of time.

Nahum Rakover mentions a good number of exegetical debates on the issue, although I will only mention a few here:

"Rabbi Yohanan infers dinim from the Hebrew word va-yetzav-'and He commanded' (Genesis 2:16), and concludes that the descendants of Noah are permitted to legislate their own laws. Rabbi Yitzhak, on the other hand, infers dinim by analogy (gezerah shavah) from the word Elokim found in the same verse. Since in the context of Exodus 22:7, Elokim (the normal meaning of which is "God") clearly has the sense of "court," here too, it may be understood as an allusion to the obligation to establish a court system. Rema explains that if the commandment of dinim is inferred from Elokim, as used to signify court of law in a Jewish legal context, then the dinim of the descendants of Noah must be the same as those of the Jewish People..."63

\footnotetext{
62 It is interesting to note that the reverse question has been asked, that is, whether Noahides can influence Jewish political systems. A deeper study of this is not possible at the moment, but I should point out that we know from Exodus 18 that Yethro (Moses' father-in-law) was worthy of influencing political activity in the Jewish community.

${ }^{63}$ Rakover, Noahide Obligation, 1099.
} 
Rather than argue about the uniqueness of Noahide law, this argument focuses on the uniqueness of one in particular, namely the requirement to establish dinim (courts); an equivalence between Jewish and Noahide court systems could imply an equivalence between the two bodies of substantive law. Stone points out that Nahmanides took a similar tack, perhaps due to his use of the medieval interpretation of the word dinim, which encompassed not only procedural law, but civil law as well. ${ }^{64}$ Maimonides, on the other hand, is credited with expanding Noahide law based on the prohibition of theft and not on the requirement of dinim. 65

In keeping with the complexity of this issue, the debate carries on. Rakover cites the opinion of Rabbi Moses Isseles who agrees with Rabbi Yitzhak that Noahides "were commanded all the laws of Israel — the generalities as well as the details, "66 only to mention Rabbi Nathan Metz's opinion:

"[I]t does not make sense that a descendant of Noah would be required to learn all of our civil law. Besides, the Bible clearly states, 'He declares His word to Jacob, His statutes and His ordinances unto Israel. He has not dealt so with any nation; and as for His ordinances, they have not known them' (Psalms 147:19-20). The sources also demonstrate that the matter is not as Rema has ruled." ${ }^{\prime 67}$

\footnotetext{
${ }^{64}$ Stone, The Sinaitic and Noahide Law, 1172.

65 Ibid., 1173.

66 Rakover, Noahide Obligation, 1100.

${ }^{67}$ Ibid., 1104.
} 
The debate rages on, involving figures such as Maimonides, Nahmanides and many others. 68

Another approach, covered by Cowen (and recently explored by Rabbi Chaim Clorfene, who analyzes the word "ger" ${ }^{99}$ ), hinges on the use of the words "rei" acho ('your fellow'), achicho ('your brother'), [and] amisecho ('your national fellow')."”0 If a Mosaic commandment mentions "one's fellow" or "one's countryman," then the application of that commandment would be limited to relations between two Jews, whereas another set of words would refer to any human, regardless of their status as a Jewish or Gentile.

\section{Rationality and the Noahide Laws}

Another general feature of the Noahide code is its almost unanimous

characterization as an inherently rational ethical code, regardless of the religious context in which the laws were revealed to mankind. The Babylonian Talmud tells us:

'And My ordinances you shall practice' (Leviticus 18:4): These are matters written in the Torah which even if they had not been written there, reason would have required that they be written. Some examples: laws prohibiting robbery, laws prohibiting incest, adultery, homosexuality and bestiality, laws prohibiting idolatry and blasphemy, and laws prohibiting shedding human blood. Even if they had not been written [in the Torah], reason would have required that they be written. ${ }^{71}$

\footnotetext{
68 Rakover, Noahide Obligation, 1105-7.

The entirety of Rakover's paper provides close readings of many different creative answers to this issue.

${ }^{69}$ Clorfene, Rabbi Chaim. "Shabbat for the Noahide." YouTube. September 2, 2014. Accessed June 5 , 2015. https://www.youtube.com/watch?v=s6Lk3E4-utU.

${ }^{70}$ Cowen, Universal Ethics, 152-5.

${ }^{71}$ Novak, Natural Law in Judaism, 73.

Also see Schachter et al., Sanhedrin, Folio 87a.
} 
The principles of Noahide law are so evident to the rational human being that they should be accepted irrespective of their Divine revelation. The inherent rationality of the laws has become the focal point for two lines of inquiry - the first explores what the concept of human rationality has to say about the elaboration of Noahide law, and the second concerns one of the more contentious debates regarding the Noahide Code, namely its categorization as natural law. Because contemporary Noahide sources generally (with only few exceptions) deny the equivalence between the Noahide Code and natural law, it would be interesting first to situate ourselves in this perspective before going on to understand how human reason affects the scope of the laws.

The categorization of the Noahide commandments as natural law has been at the center of rabbinic speculation for some time and is still strongly contested. Those who tend to see the Code as a natural law system are primarily academics. On the other hand, rabbinic and Noahide sources deny such a relation, although earlier rabbinic sources have not always yielded such a consensus. In its totality, the debate is voluminous, so much so that its breadth makes it impossible to be evaluated at great length in this thesis.

Some academics argue that, historically speaking, Noahide law must be a rabbinic philosophical attempt at formulating a natural law system. David Novak is perhaps one of the most ardent proponents of this view. He observes that the Noahide Code is essentially "Jewish recognition of right, that is, moral/legal commonality among diverse communities in humankind." ${ }^{\prime 2}$ It has been, since the modern period, crucial to Jewish

72 Ibid., 150. 
movements advocating political equality as well as interfaith dialogue, as was noted in the literature review. He traces the general presence of natural law and its role in Jewish identity through three significant phases of Jewish history: citizenship of Jews in foreign secular nation-states, the holocaust, and the establishment of the state of Israel. He claims that natural law is important in these phases because these events involved intense political interaction between Jews and non-Jews, which is precisely the purpose of natural law systems - to mediate political relations between diverse cultures. ${ }^{73}$

Other scholars try to lend Novak's thesis historical support by pointing to similarities between the Code and jus gentium in Roman law, ${ }^{74}$ yet Stone notes that "The rabbinic decision to validate certain practices [similar to jus gentium] and not others presupposes a method of evaluation. More importantly, many of the obligations of the Noahide Code have no relation to Roman life at all." 75

Still, Novak points out a variety of historical contexts (even prior to the modern era) wherein rabbinic sources are utilizing Noahide law as a litmus test with which to understand Jewish-Gentile obligations. ${ }^{76}$ We possess no texts that intimate the adjudication of a Noahide under Noahide law neither in the jurisdiction of a Jewish state nor of a rabbinic court in exile. The texts that do mention Noahide law only do so abstractly and tend to reference either the activities of biblical Noahides, or gentile

\footnotetext{
73 Ibid., 1.

${ }^{74}$ A Roman legal construct similar to international law.

75 Stone, The Sinaitic and Noahide Law, 1191.

${ }^{76}$ Novak and Lagrone, Non-Jew in Judaism
} 
activities in gentile lands (wherein Jews were citizens or aliens and unable to adjudicate cases). This all points in Novak's direction, that Noahide law was a construct meant to abstractly understand the Gentile world once the Jewish people were immersed in it through exile.

Although rabbinic sources tend to disagree with Novak's historical analysis, several do implicitly categorize the Noahide Code as a system of natural law. Thus Rabbi Hayyim of Volozhin claims that "they [Noahides] were given no instruction regarding what and how, but were rather expected to proceed according to common sense." ${ }^{77}$ Rabbi Tzvi Pesah Frank provides a similar remark and subsequently cites Psalm 147, saying that "[P]erhaps [the requirement of] dinim is different [for Noahides], for there is a great difference between their laws, which are based upon human understanding, and the laws of Israel, which were given by God at Sinai." 78 One way of possibly defining Noahide law as natural law is by deriving legal and ethical principles from the moral parables of the Torah prior to the revelation at Sinai. These would act as case studies for proper Noahide behavior. This is justified because biblical non-Jews are often punished for behaviors that had not been explicitly prohibited, indicating that perhaps a sort of natural law had been in effect and enforced by God. Yoram Hazony's analysis of Hebrew Scripture shows the Tanakh ${ }^{79}$ can be read philosophically and thus capable of yielding

\footnotetext{
${ }^{77}$ Rakover, Noahide Obligation, 1104.

${ }^{78}$ Ibid., 1105.

${ }^{79}$ The Tanakh is the compilation of the Torah (the Pentateuch), the writings known as Prophets (Nevi'im), and the writings known as Writings (Ketuvim).
} 
ethical insights of this kind. ${ }^{80}$ Suffice it to say-for the purposes of this paper-that the purported relationship between Noahide law and natural law is not farfetched if we examine the breadth of rabbinic literature throughout modern and premodern history. ${ }^{81}$

Contemporarily, however, the picture is quite different. Noahide primary sources unanimously reject such notions. The idea that there might be some equivalence between natural law and Noahide law contradicts certain tenets of faith that are central to current Noahide theology. The sources contend that if we admit Noahide law as natural law, then there is a sense in which the universality of the Code supersedes the activities and jurisdiction of a Divine being who is interested and involved in the unfolding of history. If natural law is set to rule the moral landscape of the cosmos, then there is no need to appeal to a personal God for moral guidance. David Novak points out this issue, aware that the very universality of the Noahide laws which makes it so appealing is also capable of displacing the Jewish god:

for the universality essential to the very idea of natural law seems to imply that Judaism itself must be justified by the criteria of something greater than itself. For commitment to the truth of the Jewish tradition forces one to admit that revelation presents truth that human reason cannot uncover by itself. ${ }^{82}$

The tension between the rationality of Noahide law and its categorization as natural law is real and fraught with implications. It appears that its rationality would make it an

\footnotetext{
80 Yoram Hazony, The Philosophy of Hebrew Scripture (New York: Cambridge University Press, 2012).

${ }^{81}$ For opposing views, see Rakover, Noahide Obligation, 1104-6.

This should be read in conjunction with Novak, Natural Law in Judaism.

${ }^{82}$ Novak, Natural Law in Judaism, 10.
} 
obvious natural law system, but some contend that it cannot be so because it was revealed to humans by God three times in the Scriptures. Contrary to Rabbi Frank's understanding (see previous page), one contemporary rabbinic source puts it very clearly:

In rabbinic theology, the Noahide commandments are understood as revealed law. They are of Divine origin and carry Divine authority. Nor can they be defined or classified as belonging to that category known as 'natural law'; i.e., inherent in human nature and rooted or founded in reason. ${ }^{83}$

As simple as this distinction may appear on its face, it requires complex theologically and epistemological justifications. If Noahide law is rational, then why is it not inherently "founded in reason?" What is the difference? If it is rational, then why would it have to be revealed? These questions are not moot, nor have they gone unnoticed by the contemporary Noahide movement. One author (of perhaps the most philosophically astute Noahide primary text) provides a lengthy argument regarding the nature of human knowledge and reason in order to disassociate Noahide law from natural law. ${ }^{84}$ Rabbi Cowen's argument is directed largely against the Kantian notion of ethical and intellectual sovereignty and in favor of the concept of first principles. Human reason is capable of rationalizing anything — seemingly sound and harmless premises can, by process of deduction or induction, yield ethically appalling conclusions; writers tend to reference the atrocities of Nazi Germany on this point. The premises of any deductive or inductive argument are key, but if we were to indulge in nihilism temporarily to seek the absolute first premise of any argument, the absolute why, human reason would reach a

\footnotetext{
${ }^{83}$ Yosef Green, “Universalism and/or Particularism.” Jewish Bible Quarterly 30, No. 1. (2002), 3.

${ }^{84}$ Cowen, Universal Ethics, Chapter 2.
} 
lacuna. Rabbi Cowen claims, as many Western philosophers have done, that human reason is incapable of discovering and justifying first principles (this absolute why) on its own. First principles must be given and justified by a source beyond human reason: God. Others echo these philosophical foundations summarily, but only cursorily: human reason without divine first principles is "abstract and theoretical at best." ${ }^{.55}$ More emphatically, one author states that "Atheistic philosophers can at best only commend universal human dignity; Hebrew Scripture commands it since man was created in the image of God.”86 Rabbinic authors are also quick to reference other prominent Jewish philosophers: "Maimonides postulated that the seven Noahide laws must be accepted by non-Jews as Divinely revealed, since all ethical systems require a theological framework and Divine authority." ${ }^{87}$ One rabbi echoes this point, contending that only a combination of universalism with a theological foundation will yield a valid legal and ethical system.

A universalism grounded in Hebrew scripture and biblical faith transcends all contingencies of time, place and person. Biblical universalism cannot be compromised or qualified by any human authority. Any infringement of a person's inalienable rights as a member of the human family constitutes, as it were, the denial of his Creator. ${ }^{88}$

The tendency to evade the shadow of natural law has its antecedents in earlier Jewish philosophical thought, which has evidently been redoubled in today's Noahide

\footnotetext{
85 Moshe Weiner, J. Immanuel Schochet, Michael Schulman, Joseph Regenstein, and Arthur Goldberg, Go(o)d for You: The Divine Code of 7 Noahide Commandments 2nd ed. (Ask Noah International, 2013), 10 .

${ }^{86}$ Green, Universalism and/or Particularism, 6.

${ }^{87}$ Ibid., 3.

${ }^{88}$ Ibid., 6.
} 
literature. We can see in Maimonides' characterization of the Noahide laws an application of rational metaphysical speculation. He contends there are general laws, specifics of a law, and a principle that guides one's intention in following each law. ${ }^{89}$ These principles are based on the teleology of the universe, which is predicated on the existence of a God. In other words, no one would create laws that ignore or go against the telos of the cosmos simply because following them would yield undesirable consequences. It follows then that all laws must be created and upheld with the correct telos in mind if they are to be valid. Because the ultimate telos is God, all laws ultimately serve the Divine. As a result, there exists no difference between revealed law and divine law_- "in essence, then, both are divine law." 90

Novak points out that if both Jewish and Noahide law are built on a common telos, as Maimonides has argued, then they either are or are not both natural law systems and thus they are only different by degree and not different in kind. ${ }^{91}$ This implies that various distinctions upon which Noahide theology are based would become invalid. We could take Maimonides' argument, for example. If the telos of both systems are identical, then this would eliminate the kind of distinction established earlier by Stone, that Noahide law is distinct from Sinaitic law because the former focuses on the mundane whereas the latter concerns the ideal standards of justice that sanctify a people near to God.

\footnotetext{
${ }^{89}$ Novak, Natural Law in Judaism, 96.

${ }^{90}$ Ibid., 106.

${ }^{91}$ Ibid., 134.
} 
As interesting and crucial as these rational underpinnings may be to the Noahide Code, we should put a pause to this digression. These examples only serve to show that although Noahide law is not portrayed as a natural law system in its most recent iterations, the inherent rationality of the laws is not ignored. The Noahide laws are certainly rational, but their rationality only becomes perfectly clear once we have understood the first principles which underlie them, that is, once we have understood the Divine will which authored these laws.

I noted at the beginning of this section that the inherent rationality of the Noahide code is a premise through which the details of the laws are elaborated.$^{92}$ It is to this point that we revert. Rabbi Cowen, among others, argues that

Noahide law consist of three parts: (1) the seven Noahide laws and other laws of the pentateuch and rabbinical commentary which explicitly pertain to all of humanity, (2) whatever else is rational and is indicated as such by Scripture, (3) laws which were made by humanity but were created in order to fortify Noahide law and the social order. ${ }^{93}$

The second point is key to our understanding. He goes on to say that because "Rationality (Divinely formed and defined) is the basic character of Noahide law, providing for the harmonious habitation of the world," Noahides should be required to observe all other rational laws found in the Sinaitic Code. ${ }^{94}$ A related view, noted by Rabbi Cowen, holds

\footnotetext{
92 Stone, The Sinaitic and Noahide Law, 1181. Sources from the medieval period "do not mention objective reason as a criterion for validating the rules of non-Jewish legal systems."

${ }^{93}$ Cowen, Universal Ethics, 147.

${ }^{94}$ Ibid., 155.
} 
that if a law is concerned with mediating a gross character trait, then it too should be observed.

Other sources concur with these opinions, pointing out how the inherent rationality of the Noahide laws means a number of other ethical and legal mandates can be easily deduced and implemented:

In addition, every human being is expected to follow principles of action that can be deduced by unadulterated common sense that is based upon the axioms evident from the above mentioned seven laws. Examples of this are the obligations of giving charity to the poor and hospitality to travelers, as well as not displaying disrespect toward one's parents. ${ }^{95}$

Another excerpt illustrates an example of this, in this case viewing the prohibition of desire as incumbent upon Noahides:

A person is forbidden to desire the property and physical dwelling place of another as expressed by the scriptural verse, 'And you shall not desire your neighbor's house nor his field, nor his manservant nor his maidservant nor his ox nor his ass nor anything that is his' (Deut. 5:18) Since the Children of Noah are commanded to withhold themselves from committing theft, they are similarly commanded concerning deterrents to that transgression, namely desire. ${ }^{96}$

Noahide primary literature provides various examples of laws expanded in such a manner, but exploring each case is unnecessary for our purposes. The point is that because the Noahide laws are rational and form the minimal ethical standard, all other rational principles should be followed by Noahides as well.

\footnotetext{
95 Sitzman, Yechiel. "Theology and History." Oklahoma B'nai Noah Society. Last modified 2003. Accessed December 15, 2014. http://www.okbns.org/Theo_History.html.

${ }^{96}$ Clorfene and Rogalsky, Introduction to the Noahide Laws, Chapter 10, Points 16 and 17.
} 
This chapter has addressed a number of rhetorical and philosophical approaches to defining scope of Noahide law, as well as determining the framework for its jurisdiction and legislation. The rhetoric has thus far sought to expand Jewish influence, but some writers do take exception to this. Michael Dallen, for example, believes that Noahides should be responsible for their own laws; $;{ }^{97}$ Alan Cecil, another contemporary writer sides with and cites Dallen in his own work. ${ }^{98}$ In their view, Jewish rabbis are meant aid Noahides by describing matters of Torah rather than prescribing law for Gentile nations. ${ }^{99}$ Dallen and Cecil support minimal Jewish influence; the former is Jewish, but not rabbinically ordained, whereas the latter is a Christian-turned-Noahide. In contrast, contemporary rabbinic writers seem to promote greater Jewish influence in Noahide law.

The precise nature of the correlation between identity and one's position on the issue of scope is unclear to me. A closer reading of contemporary Noahide texts is inconclusive, insofar as I am unable to distinguish just how identity might affect one's inclination towards dependence on Jewish legislation. ${ }^{100}$ Only Cecil's stance on the issue is clear. The other two writers do not take a clear philosophical or halakhic position, perhaps because their work is autobiographical and concerned more with their personal

${ }^{97}$ Michael Dallen, The Rainbow Covenant: Torah and the Seven Universal Laws (Springdale, AR: Lightcatcher Books, 2003), 80, 83, 84, 133. Regarding marriage and divorce, see 157. Regarding incest, see 156. Regarding feticide, see 197. Regarding idolatry, see 279.

\footnotetext{
98 Alan W. Cecil, The Noahide Code: A Guide to the Perplexed Christian (Pompano Beach: Academy of Shem, 2006),

95.

${ }^{99}$ Dallen, The Rainbow Covenant, 79.

${ }^{100}$ Kimberly E. Hanke, J. David Davis, and Alan Cecil.
} 
transformation from devout Christian to Noahide. Cecil's opinion alone is not sufficient to warrant a generalization. In fact, the data best suited to infer a generalization contradicts Cecil's stance. As we will see later in the Noahide Individuals Survey, there seems to be a general desire for increased Jewish influence among contemporary Noahides.

Dallen's work, which deals more intimately with the question of scope than Cecil's, is also potentially inconsistent. On the one hand, Dallen seems to advocate a Noahide code smaller in scope adjudicated and legislated by Noahides. Then again, he maintains that violations of Noahide laws "aren't just crimes committed against other men, offensive to the good order of society. They [any violation] are crimes of idolatry, committed against God and His sovereignty, which are directly offensive to Him."101 Dallen makes this remark when discussing the issue of capital punishment. Still it seems to me that such a outlook would commit him to a Noahide Code more in line with Jewish standards of adjudication and legislation. It would appear somewhat laissez-faire to allow Noahides to legislate their own laws if indeed any violation is so egregious so as to be directly offensive to God and warrant capital punishment.

The issue of scope is not one to be solved in this thesis, but only to be fleshed out in the context of contemporary Noahidism. I only mean to point out conceptual tensions which could influence identity. The final aspect of the Code which we will examine in this light will be the concept of punishment.

101 Dallen, The Rainbow Covenant, 85. 


\section{Punishment and the Noahide Laws}

The issue of punishment in the Noahide code is not a highly contentious point of Noahide identity, but it is another feature of the laws which opens doors to broader philosophical questions regarding the adjudication of Noahide violations as well as contemporary efforts to flesh out the precise nature of the code. In general, we can say that there is a certain inequity between the laws of Noah and the laws of Moses, and explanations for this inequity (often in the form of apologetics) feature often in contemporary Noahide literature. Rabbinic sources state that the violation of any Noahide law is punishable by death, specifically beheading. As a corollary, some sources maintain that the violation of rabbinic injunctions related to the seven laws does not prohibit one from the world to come, but it will bring divine retribution of some kind. Rabbi Bar-Ron, a contemporary author, justifies capital punishment by arguing that these laws are the fundamental fabric of society. ${ }^{102}$ Without adherence to these laws, all other social mechanisms fall apart. Capital punishment would, he argues, ensure the observance of these ethical cornerstones. This argument must answer to a couple of contentions. First, assuming Bar-Ron is correct, it still does not prove capital punishment is the most affective way to instill ethical values upon a society. What is more, if these laws are so fundamental to the fabric of society, how is it that the Jewish people do not also receive capital punishment for similar transgressions?

\footnotetext{
102 Michael Shelomo Bar-Ron, Guide for the Noahide: A Complete Manual for Living by the Noahide Laws. 2nd ed. (Springdale, AR: Lightcatcher Books, 2010), 7.
} 
Attempts to resolve the purported discrepancy between Jewish and Noahide schedules of punishment tend to be either Scriptural and/or apologetic. Put frankly, "Here, the Torah took pity upon Israel and provided for more lenient penalties." 103 Inconsistent with this notion is the tendency for writers to emphasize how Jewish punishment is more severe than Noahide punishment in many cases. ${ }^{104}$ Other arguments tend not to explain away the inequity, but rather propose that the difference between the two schedules is a theoretical and not practical one. Dallen claims that Moses taught capital punishment is reasonable only in cases of murder. ${ }^{105}$ In all other cases, the prescription of capital punishment merely indicates the importance of the Noahide laws. This is in fact the most popular explanation for the severity of Noahide punishment. Even Rabbi Bar-Ron, who above advocated capital punishment, is quick to agree with Dallen and company. ${ }^{106}$ Capital punishment is a symbolic benchmark and too drastic for everyday implementation; the only condition under which the enforcement of the death penalty would be justified is if society were to find itself in dire ethical straits - perhaps in something like a Hobbesian state of nature. Because this standard of retribution must not actually be enforced, Dallen suggests, and Cecil agrees, that each nation should determine their own schedules of punishment. ${ }^{107}$

\footnotetext{
103 Rakover, Noahide Obligation, 1085.

${ }^{104}$ Bar-Ron, Guide for the Noahide, 10, 49.

${ }^{105}$ Dallen, The Rainbow Covenant, 33.

106 Ibid., 83.

Also see Bar-Ron, Guide for the Noahide, 8.

${ }^{107}$ Cecil, The Noahide Code, 95.
} 
The issue of punishment then returns to the question of sovereignty which, as we saw, is tied directly to issues of scope. It was mentioned briefly that one point of contention in these debates regards how certain Hebrew words refer to whom laws apply. Certainly an analysis of these linguistic problems would be fascinating, but they are far too extensive for the scope of this paper. Still the issue of language brings me to the following point. It seems to me that Noahide publications tend to obscure the underlying logic of halakhic arguments due to the ways in which they are formatted and presented. Some texts tend to be poorly cited. In cases where citations are bountiful, it is still often difficult to obtain and reference the relevant Talmudic or rabbinic excerpts. Referencing these excerpts may be helpful, but then leads to the issue of interpretation - how might a rabbi be interpreting a certain word in the Talmud? Perhaps one way to evade these issues of language and presentation and provide a clearer understanding for Noahide readers is for new publications to provide a source-friendly format and then offer commentary to the original source. We can imagine using the Talmudic format for Noahide texts as a way to bring readers directly to the original sources and then provide contemporary commentary on the fringes of the pages.

This format would clear up some of the confusion regarding the typology of nonJewish persons, for example. As we will discuss later on, the translation of typological terms plays a crucial role in variations of Noahide law and has even led to a case of Noahide sectarianism. Setting these crucial ideas to paper in a Talmudic format would help to centralize the debate and make dialogue much easier to follow. Most importantly, 
it would draw Noahides closer to the Jewish tradition, which they are seeking to do in many other ways. 


\section{CHAPTER 3}

\section{IDENTITY AND RELIGIOUS PLURALISM}

As we just saw in the chapter on law and identity, the very foundation of Noahidism is riddled with conceptual dilemmas which make a singular and monolithic code of Noahide law difficult to derive. I am not implying Noahidism as a movement is flawed or unfeasible; the tenets of Noahide law seem to be broad and stable enough to unite practitioners even if they disagree on the scope of the laws. So we should not see these differences in opinion over the nature of the Noahide law as the cause of any major schism in the Noahide community. In other words, there is no evidence to suggest that competing views of Noahide law among contemporary practitioners has caused a significant schism or sectarian divide in the Noahide community. As far as my research shows, differences of opinion regarding the scope of the law tend to enhance interaction among Noahides. I am not sure if this means Noahides are generally pluralistic about how they understand their principles. Instead it seems there is still so much uncertainty that discourse is approached in an open-minded way because practitioners have not yet polarized around fixed schools of thought.

Yet for all of the confusion that surrounds the interpretation of Noahide law, there is one area in which no equivocation exists, namely the issue of religious pluralism. I set out at the beginning of this thesis to show that Noahidism is the lay order of Orthodox Judaism, and it is in this chapter that we begin to show the intimate connections between these two groups. I hope that the point will be fairly clear by the end of this chapter, and 
that the subsequent chapters only provide supplementary evidence to my argument. My primary contention here is simple. Contemporary Noahidism is a lay order or Orthodox Judaism because the primary literature states unequivocally that Noahides must renounce faith in all other deities and accept the Jewish God as the one and only deity. This point shows that Noahides are tied to Orthodox Judaism as a matter of faith. What makes Noahidism a lay order is the way in which Orthodox Jews describe themselves as the priests of God, here to lead humanity to belief in the one true deity.

There are also various pieces of evidence involving ritual, conversion, and sectarianism which make the lay-priest relationship clear, but we will leave these for later. These other aspects of Noahide identity are premised upon Orthodox legal constructs (discussed in the previous chapter) and upon the principles of faith we will discuss shortly. I think the best way to delve into the question of Noahide faith is by first looking at the question of religious pluralism. It is arguably one of the more prominent features of contemporary Noahide thought although it is certainly not novel. Pluralism is found in connection to Noahidism early in the rabbinic literature. As far as I can tell, however, it is today referenced in somewhat vague terms and is presented as more of a selling point than a fundamental principle of contemporary Noahidism. The earlier rabbinic sources initially convinced me Noahidism could be the basis of a universal ethical code indifferent to religious creed, but my reading of the contemporary sources has radically changed this view. I argue instead that religious pluralism or even inclusivism have nothing to do with Noahide law or the contemporary Noahide 
movement. In fact, the movement is certainly religiously exclusive. If there is a place for pluralism or inclusivism in Noahide ideology, it would be on a legal and cultural level.

\section{The Noahide Laws as a Medium for Pluralism}

Orthodox Jewish sects are not known for putting much stock in notions of religious pluralism or inclusivism, although Jewish thinkers have entertained these ideas before. Dan Cohn-Sherbok notes the work of David Hartman and Louis Jacobs as possible foundations for a theory of religious pluralism faithful to the Jewish tradition. Hartman in particular sees that the covenant of creation keeps humans connected to God, whose revelations are always fragmentary, incomplete, and relevant to a people's sociohistorical situation since the Divine's essence cannot be exhausted. ${ }^{108}$ Norman Solomon continues this line of argument and even invokes the Noahide laws. In his view, the Jewish spiritual mission encompasses the improvement of humanity as embodied in the laws of Noah, which demands "faithfulness to the highest principles of justice and morality" rather than conversion to Judaism. ${ }^{109}$ Solomon says elsewhere in the spirit of modernity that Judaism

cannot set the bounds of truth; we must listen and try to learn, grow in experience and forge language, remain open to the world around us with its myriad peoples and ways, and read and interpret the words of scripture and sage constantly, critically, in the context of our own age and society. ${ }^{110}$

\footnotetext{
${ }^{108}$ Cohn-Sherbok, Judaism and Other Faiths, 9.

109 Ibid., 10.

110 Ibid., 10.
} 
Other rigorous contemporary arguments for religious pluralism tend to rely on principles found in Western philosophy. One such example is a position advocated by Cohn-Sherbok, who invokes Kantian metaphysics. If Kant is right that human sensory and intellectual faculties cannot perceive the complete nature of any entity (the thing in itself) however sacred or mundane the entity may be, then humans are unable to have a complete understanding of the Divine. Every religious tradition would have a limited and often variant understanding of the Divine essence and of its own religious tradition, such that no tradition could claim to possess a superior insight or revelation. This view has broad appeal in that its premise relies on an understanding of human nature as opposed to speculation about the Divine essence. Moreover, the premises of this argument are also secular, independent of a religious tradition, and therefore applicable to all religious traditions that agree with the Kantian principle.

Having said that, analyses of religious pluralism from the Orthodox perspective tend not to stray too far from Scriptural exegesis and halakhic ruling; Western rationalist metaphysics is not a staple of Jewish theology, historically speaking, and it is only given serious attention beginning with Maimonides. When looking at the Orthodox perspective, we can first examine statements which, when taken on their own, imply a sort of pluralism or a commitment to morality independent of theistic revelation. The latter notion is attested to in Hillel's instruction to a prospective convert. He teaches the convert that the core of Judaism can be surmised in one maxim: "what is harmful to you do not 
do to your fellow," all else is "commentary."111 This principle does not invoke the existence of a God; it appeals to a universal ethic independent of theism, but it is just short of advocating religious pluralism or inclusivism.

Others have argued along different lines, like Moses Mendelssohn: "Brothers, if you care for true godliness, do not pretend that conformity exists where diversity is obviously the plan and goal of providence." 112 Mendelssohn is perhaps taking an exegetical tack in making such a statement, referring to a Divinely imposed plurality as read in the story of Babel and the subsequent dispersion. ${ }^{113} \mathrm{He}$ is attempting to point out that because plurality is a Divinely-ordained state of affairs, Jews must live their lives in harmony with these conditions. Concerns of righteousness and justice are not exclusively Jewish, but involve all peoples. One author points out the Scriptural basis for Mendelssohn's conviction, saying that "The Torah describes Abraham as bargaining for the lives of the depraved Sodomites out of his profound conviction that God's universality finds expression in the punishment of sinners precisely because $\mathrm{He}$ is the Author of a moral law, universal in scope." ${ }^{114}$ Abraham's concern for the people of Sodom is not based on their religious affiliation, but on their moral worth as human beings.

Still, all of these insights indicating a Jewish concern for a universal ethic only hint at the possibility of religious pluralism, but do not lead us directly to it. At best, they

\footnotetext{
111 Novak and Lagrone, Non-Jew in Judaism, 26.

112 Cohn-Sherbok, Judaism and Other Faiths, 84.

113 For the story of the Tower of Babel, see Gen. 11:1-9.

114 Green, Universalism/Particularism, 1.
} 
imply a sort of religious tolerance in which the moral dignity of each human being is paramount and their religious affiliations are a secondary matter to be dealt with later. To force the issue, Cohn-Sherbok points out that the Scriptures do not highlight the immorality of idolatry for non-Jews. Instead, the Scriptures emphasize Noahide violation of other moral laws. ${ }^{115}$ Idolatry is shunned insofar as God prohibits Jews from practicing it because they have chosen to believe in the God of Israel as the one and only God. It is worth pointing out, even if only cursorily, that whereas the Noahide laws of blasphemy and idolatry are negative, the Jewish commandment regarding belief in one God is positive. $^{116}$

It is only in the rabbinic period that such a strict prohibition on idolatry is enacted for Noahides by means of the Noahide laws. ${ }^{117}$ And even then, there is a sense of flexibility. The debate between R. Hanina and R. Johanan demonstrates how Gentiles are permitted to use intermediaries to worship the one true God, whereas the Jewish people worship God directly through the performance of the commandments, without intermediaries. ${ }^{118}$

Such rulings demonstrate an inclusivist disposition which accepts Christianity and Islam as legitimate monotheistic religions. Maimonides and Judah Halevi have been cited as proponents of religious inclusivism, albeit to varying degrees. Both, however, believe

\footnotetext{
115 Cohn-Sherbok, Judaism and Other Faiths, 25-9.

${ }^{116}$ See Deu. 5:6 and Ex. 20:2 for this commandment.

117 Cohn-Sherbok, Judaims and Other Faiths, 29.

${ }^{118}$ Ibid., 30, 35.
} 
Christianity and Islam are capable of preparing the world for the messianic age because the former upholds the authority of the Hebrew scriptures while the latter upholds the philosophical validity of monotheism. ${ }^{119}$ These notions are echoed again after the Enlightenment in the works of Joseph Salvador (1779-1873), Samuel Hirsch, and Solomon Ludwig (1789-1866). Their worldviews also incorporate the Noahide laws. One argument found in this literature states that practitioners of Gentile religions are potentially "anonymous Noahides" if they also follow the laws of Noah. From this perspective, the laws are not only a normative legal system which justifies Jewish interaction with non-Jewish communities, but also an extension of Jewish theology allowing Gentiles to attain salvation through their own merit despite never having heard of the Noahide laws.

This position does not have the same cachet in contemporary Noahidism. Surely some practitioners might be interested in accounting for the validity of other religious traditions, but these individuals are in the minority given that most Noahides are converts who have rejected their previous religious beliefs in favor of exclusive identification as B'nei Noah. This does not make the question of inclusivism moot, but it is simply not a question being asked with much urgency given the background and general disposition of Noahide practitioners. The purpose of the Noahide laws in contemporary literature is to provide a pathway for Gentiles through which they are capable of contemplating, living, and realizing Jewish religious truths "without requiring their conversion to Judaism."120

\footnotetext{
119 Ibid., 36-42.

${ }^{120}$ Ibid., 10.
} 
Ultimately, we will see that this pathway does not accommodate pluralism and only reluctantly admits to inclusivism in ambiguous terms. Contemporary iterations of the Noahide laws harm the purported objectivity and universalism of the Noahide movement, turning it into a kind of Judaism-lite. ${ }^{121}$ As far as I can tell, the possibility of religious pluralism and inclusivism has not been explored in great detail by Noahide literature. Exclusivity is the order of the day and Orthodox Jewish notions of exclusivity are fairly solidified in theory as well as practice among Noahides.

\section{Is Noahidism a Religion?}

Before we can investigate the primary literature and demonstrate Noahide exclusivity, it is important to first deal with another substantial aspect of Noahide rhetoric and identity: contemporary Noahides generally believe that Noahidism does not constitute a religion. It is generally agreed by primary sources and practitioners that Noahidism is not a new religious tradition or not a religion at all. The latter is the more striking assertion given the fact we tend to categorize Judaism as a religion. If Noahidism is so closely related in belief and practice to Judaism as it is claimed to be, how does it escape classification as a religious movement? My contention is it cannot.

By looking at the primary sources, I believe contemporary writers are merely relying upon a very distinct definition of 'religion.' Noahidism is certainly a religion if we employ the more commonly accepted definitions of either Paul Tillich or Melford E. Spiro. The former describes religion as concern for ultimate meaning in life, whether

\footnotetext{
${ }^{121}$ Ibid., 168-9.
} 
aesthetically as "the infinite desire to express ultimate meaning," or intellectually "as the passionate longing for ultimate reality." Spiro defines religion in anthropological terms as “an institution consisting of culturally patterned interaction with culturally postulated superhuman beings" or alternatively "supernatural" beings. ${ }^{122}$ No contemporary Noahide text to my knowledge explicitly provides a working definition of 'religion,' so at best we can infer their conception of religion by piecing together hints from the primary literature. What is clear, however, is that their idea of religion does not match that of Tillich's or Spiro's.

It may be obvious to some readers that Noahidism is a religious movement even from the little we have explored so far. Nonetheless, I think it is important to inquire deeply and develop a strong case here because doing so would unpack a good deal about Noahide identity. We can start by looking at the Noahide idea of universalism. It is premised on the belief that we are all made in God's image, an idea found in the book of Genesis, 1:27. The only way to fulfill human potential is to tap into the divine spark each individual possesses, a process that is facilitated and enhanced by observance of the Mosaic and Noahide laws. Contemporary secular legal codes are unable to aid humans in the realization of their divine qualities. One author puts it succinctly that "Self respect and respect for all who were created in His image demands more than a fragile and tentative secular social contract." ${ }^{, 23}$ One understanding of the Noahide laws, as they are

\footnotetext{
122 Jonathan Z. Smith,"Religion, Religions, Religious." In Critical Terms for Religious Studies, 269-84 (Chicago: The University of Chicago Press, 1998), 281.

123 Green, Universalism and/or Particularism, 7.
} 
understood and communicated today, is that they are concerned with the social and therefore the mundane, but only insofar as proper socio-political arrangements are preconditions for the ultimate goal of tapping into the sacred dimension of human experience. The Noahides laws are concerned with secular space, with society at large, but the code itself is not secular. A secular legal code, uninspired by the Divine essence, will not help humans organize society and behavior in such a way that will enable the spiritual refinement of human beings. The ultimate concern of our political and ethical life is focused on the presence and workings of a supernatural being.

Still, the insistence that Noahidism escapes the ambit of religion is evident:

We see now that, unlike Israel's covenant at Sinai, the Noahide covenant is not a religion that one must convert to, a people one must be accepted into. It is the Divinely-ordained legal, social, moral, and spiritual framework that non-Jewish human beings are born into - just as we are all born into a natural framework of physical laws and limitations... It requires no religious ceremonies, requires no sacrificial service, no priestly hierarchy. ${ }^{124}$

Another author, a Noahide by the name of Alan Cecil, argues that the laws of Noah (as part of the Jewish tradition) cannot be a religious movement because Judaism does not advocate organized religion for non-Jews. ${ }^{125}$

It is interesting to track Cecil's argument because it highlights interesting and common ways in which Jewish ideology is portrayed in the primary Noahide literature. He claims that "To understand Noahide Law from an intellectual and

\footnotetext{
124 Bar-Ron, Guide for the Noahide, 3-4.

125 Alan Cecil, Secular by Design: A Philosophy of Noahide Laws and Observances (Pompano Beach: Academy of Shem, 2011), 25.
} 
rational perspective, one has to be familiar with the concepts in the Torah..." Because of this, we might again assume Noahidism is a religion much like Judaism because we would consider the Torah a sacred text, but he strives to avoid this classification by denying that even Judaism is a religion. The Torah, he says, "makes no essential distinction between 'matters between a man and his Creator' ... and those 'between man and his fellowman'... because the structure of relationships between human beings is intimately connected to the relationship between man and his Creator."126 A dichotomy between religious and secular institutions, he argues, would harm our understanding of Judaism and Noahidism. Cecil goes on to claim the Torah is not a text on religion, and yet, it is a text that communicates how the Divine wants us to lead our lives. It is more a book of law than of theology or religion, and this is especially true for any Noahide who strives to learn the Torah. ${ }^{127}$

Many Noahides share Cecil's position. They point to the fact that the Jewish people are the first and only nation established by God, meaning that its divine mandate is of a political and ethical nature and not of a religious one. Even if we would like to fit everything the Jewish people are, do, and think into an ism, this ism should not be categorized as a religion, but as something that transcends religion and encompasses the secular as well. The legal tradition and original geographic exclusivity of Judaism make it a nationalistic ethic or philosophy. This

\footnotetext{
${ }^{126}$ Cecil, Secular by Design, 27.

${ }^{127}$ Ibid., 29.
} 
stands in opposition to other religions which are transnational and trans-ethnic, and have not been imbued with a legal or ethical model for the express purpose of establishing a political community and maintaining its ethical purity. As the foundation of Sinaitic law, Noahide law is primarily concerned with social peace rather than conformity with theological dogma. This is, at least, one strain of thought on the matter

But there are various issues at hand with these opinions. Just because Judaism makes no distinction between the mundane and the sacred does not mean the difference does not exist, or that the distinction is not valuable from another perspective. When we say there is no such thing as religion or secularism from within the Jewish worldview, we might be saying one of three things: that only secularism exists, that only religion exists, or that neither exist. But I think there is confusion about what is being argued over. Would any rabbi deny there are things and people in this world who have no care for or orientation towards the Divine? Of course not. These entities are non-religious entities.

When these authors claim there is no dichotomy between religion or secularism in Jewish thought, they are saying there is nothing which is inconsequential in God's eyes. Everything has an affect in the cosmic drama that is our universe. Any person is very much entitled to this opinion, but to deny the existence of religious and areligious objects, thoughts, and behaviors is problematic. 
These individuals are also welcomed to use any term they desire. Take Dallen's work, for example. He describes Noahides and Jews as those who have decided to knowingly "embody righteousness." ${ }^{28}$ We could approach the situation using this terminology. Rather than invoke the categories of religion and secularism, we can turn the dichotomy between the religious and areligious into an ethical one. The Jewish faith is nothing more than the path of righteousnessall other paths, paths of unrighteousness. In this view, the atheist is someone who has consciously and purposefully decided not to embody righteousness. The point is that when we play the Jewish language game, this also means the atheist has kept from engaging the sacred, the ultimate meaning, the supernatural, and yet they cannot escape the workings of the sacred which permeates all; there is, in the eyes of the pious Gentile or Jew, no secular realm to which to retreat.

Dallen states that Judaism is a "way of life, a way of eating, thinking, and knowingly trying to embody righteousness" that does not discriminate between the mundane and the sacred - the sacred permeates every moment of human existence." ${ }^{29}$ That an act like eating or sex might be religious is merely the reflection of the way in which individuals direct their intentions, so that when someone has left God out of their mind, they are essentially being non-religious, unrighteous, unpious, whatever term you prefer to use, it is all the same. I do not intend to be pedantic, but it is a point worth stressing simply because it is a

\footnotetext{
${ }^{128}$ Dallen, The Rainbow Covenant, xii.

${ }^{129}$ Ibid., xii.
} 
contention held so firmly in contemporary Noahidism. In reply to the contemporary Noahide literature, I would say the following: when one says that Judaism and Noahidism are religions, one is only committed to the idea that these traditions are patterns of symbols and concepts which facilitate one's conscious striving for ultimate reality, as opposed to patterns of symbols and concepts which have nothing to do whatsoever with the Divine or ultimate meaning in life.

And yet the oddity of the situation is that these same texts which deny Noahidism's status as a religion (emphasizing its secular, sociopolitical slant) also revert to the concept of a first principle (following Cowen and Maimonides) which states that proper understanding and observance of the Noahide laws is premised on belief in the Divine. It is clear then that these Noahide texts are operating under a very strict definition of religion. How else could they deny the construct of religion and yet advocate a lifestyle premised upon belief in a supernatural entity? For all of Cecil's exertions to prove the Noahide Code is a secular system, he asks his readers: "Are humans free to do what we feel is right in our own eyes, or is there a divine standard of conduct?"'130 There is a divine ground upon which the Noahide law is supported.

The contradiction here is lost on the writers of these texts due to their operational definition of religion which, although never explicitly stated, appears to be a more materialist definition. Spiro's and Tillich's definitions focus on the intention of humans-

\footnotetext{
${ }^{130}$ Cecil, Secular by Design, 81.
} 
their orientation towards the ultimate in life. This is not to say we cannot identify religious artifacts. A Torah scroll or mezuzah and other such sacred objects are intended to bring man closer to the Ultimate, and for that reason we call them religious. Sexual intercourse and eating can similarly be turned into religious artifacts if we maintain a certain intention while engaging in these acts, just like a spatula can at one moment be wielded as a pancake flipper and at another time a tool to discipline an unruly child. But intention alone does not constitute religious practice in contemporary Noahide texts.

The Noahide concept of religion is intimated by a few excerpts found in the primary literature. Take Rabbi Bar-Ron's statement that Noahidism is not a religion because it "requires no religious ceremonies, requires no sacrificial service, no priestly hierarchy." ${ }^{131}$ This view of religion is more akin to Ninian Smart's criteria. ${ }^{132}$ In that case, Noahidism lacks a material or ritual aspect, meaning it is not a religion. But this view ignores the possibility that ritual and custom could develop on a voluntary basis and propagate themselves as a matter of tradition without depending on the force of mandate and coercion from the community or the Divine. It also fails to account for the cases in which some members of a community are prohibited from scared ritual and material artifacts, as is the case in Noahidism. And I think this is the point, that Noahides are not commanded to perform rituals and in many cases are even prohibited from ritual. This does not mean there is no ritual, but that ritual is off limits to them as if they were lower

131 Bar-Ron, Guide for the Noahide, 10.

132 Smart identifies seven dimensions as being the defining characteristics or religion: ritual, narrative and myth, experiential and emotional, social and institutional, ethical and legal, doctrinal and philosophical, and material. 
level initiates of a religion, sect, or cult that does have ritual for the higher level initiates.

With this in mind, I would argue that Noahidism, in conjunction with Judaism, is a religion even under Smart's definition.

Other sources do not aim to separate Noahidism from the classification of religion. Their interest is in communicating the fact that Noahidism is not a new religion, but rather the first religion of mankind. Hanke writes that "We are witnessing the true emergence of a movement, not a new religion, but rather an existing Torah religion that is newly practiced. This is an unfolding of God's plan in the fullest sense." 133 Another author says similarly that

The matters that we are trying to explain in this work are not in any way an effort to try and establish a new religion. It is rather an attempt to look at the Scriptures and other Torah literature and reach conclusions concerning what a person should do or try to do...In order to help all those among the nations who are looking for ways to come closer to G-d. ${ }^{134}$

The belief that contemporary Noahidism is not a new religion, but a continuation of an ancient religious tradition is surely a means to legitimize Noahidism with some form of historical and biblical authenticity and value. But this thesis is problematic simply because there exist no historical records attesting to the existence of individuals who consciously identified as observers of Noahide law. There are no records of their activities or trials. As already mentioned, texts which do discuss Noahide activity and law do so with reference to Gentile activity in Gentile lands during Jewish exile. These

\footnotetext{
133 Kimberly E. Hanke, Turning to Torah: The Emerging Noachide Movement (Northvale, New Jersey: J. Aronson, 1995), x.

${ }^{134}$ Yoel Schwartz and Yitzhak A. Oked Sechter. "Noahide Commandments," Oklahoma B'nai Noah Society, 2004. Accessed June 7, 2015. http://www.okbns.org/R_Schwartz_Intro.html, 1.
} 
Gentiles were neither ger toshav (resident aliens) nor conscious Noahides. The only other source of Noahide history would be the Scriptures, but there are two issues here. First, we would have to accept the Scriptures as a valid historical account, which many scholars are reluctant to do. Secondly, even if we were to accept the historical validity of Scripture, the Tanakh does not make explicit reference to Noahide laws or to the activity of individuals or communities who consciously accepted them nor does it acknowledge their existence. The Talmud does talk about Noahide laws, but does not mention the lives of Noahides or their place in Jewish society in such a way that can be historically verified.

It is clear then we cannot accept the idea that Noahidism is an ancient religion as a matter of historical fact. Nevertheless, the claim is instructive regarding how Noahides understand their identity and strengthens their tie to Orthodox Judaism, which agrees with this conception of history.

There are plenty of reasons to label Noahidism as a religion. There is a clear focus and intention to engage the ultimate meaning of existence which is unequivocally related to a divine being. But even then Noahide primary sources maintain that the primary purpose of Noahide law is to promote social, secular well-being. This claim is easily contradicted by the Noahide belief that observance of the seven laws of Noah is a precondition for spiritual salvation. This belief puts Noahidism back in the realm of religion. 


\section{Salvation}

The first important aspect of Noahide theology is salvation. I say first not because of any logical priority, but actually because this is the first explicit consequence of proper observance found in the rabbinic literature. The earliest mentions of the Noahide code are responses to a distinct query: who will attain the World to Come? For all of the emphasis placed on the social consequences of Noahide law, it is clear that proper observance also has cosmic implications. One author writing on salvation and the Noahide code defines salvation as

deliverance to some new and transformed situation to which God's promises deliver us. Whether salvation is viewed as a this-worldly notion or considered to be a reward in the afterlife, all religious faiths hold it out as a promise and expectation, a reward for virtuous, moral, righteous, and pious living. ${ }^{135}$

The second spiritual consequence of proper observance is drawing down the divine presence into Earth, although this is an admittedly Hassidic view. It is clear in the Hassidic literature that the performance of the Mosaic commandments invites the divine presence onto Earth. It is not surprising to see some contemporary Hassidic authors apply the same cosmic power to the observance of Noahide laws. ${ }^{136}$ Determining which consequence is more important from a philosophical or theological perspective is not relevant to our discussion. What is more pertinent is understanding how Noahides

\footnotetext{
135 Rosenthal, Gilbert S. "Hasidei umot ha-olam: a remarkable concept." Journal of Ecumenical Studies 48.4 (2013): 467-490 .Academic ASAP. Web. 4 Aug. 2014, 467.

136 See Yakov David Cohen, Divine Image (New York: Institute of Noahide Code, 2006). Also see Yitshak Ginsburg and Moshe Genuth, Kabbalah and Meditation for the Nations (GalEinai Publication Society, 2007).
} 
emphasize these doctrines in their behavior and practices. Textual evidence suggests that Noahides are indeed concerned with the social aspect of Noahide law, but a sample of four texts is unreliable given that two of them are autobiographical, do not delve deeply into Noahide theology, and talk about the transformation from Christian to Noahide and not the nuances of life as a Noahide. It is also not unreasonable to believe that most Noahides might be more concerned with the spiritual application of the laws. The survey data shows that an overwhelming percentage of Noahides were Christians at one time. ${ }^{137}$ Many converts may have remained with their Christian inclination towards the spiritual and aversion to the political dimensions of religion. The spiritual may also be emphasized above the social because there are currently no political institutions through which to codify and enforce Noahide law.

Although I can only speculate about what living Noahides emphasize, the doctrine of salvation remains interesting to us because of the conditions placed on it. First, Noahides must observe the seven commandments (and arguably the rational commandments among the Sinaitic code). As I have already mentioned, the connection between the laws and salvation shows again that Noahidism fits perfectly into the ambit of religion, but it is the next condition which places Noahidism in the sphere of exclusive religion: humans must observe the seven laws as a matter of divine revelation, specifically the revelation of God to Moses at Mount Sinai. This point is agreed upon unanimously by contemporary texts, and most go as far as to deny any spiritual reward if

\footnotetext{
${ }^{137}$ Noahide Individuals Survey, Question 11.
} 
one adheres to the laws without accepting this article of faith; following the Noahide laws because they make rational sense confers a practical reward on individuals, such as economic, political, and social well-being. ${ }^{138} \mathrm{~A}$ person attains a spiritual reward only for accepting the laws of Noah as principles revealed by the Jewish God. 139

\section{Noahidism as an Exclusive Religion}

The significance of these doctrines is not so much theological as it is taxonomical. The concern with salvation and its conditions not only make Noahidism a religion, but an exclusive one at that. Judaism calls non-Jews to believe in and worship the Jewish God, although not in the way that Jews worship. The ability to practice differently should not be mistaken for pluralism. This difference is more akin to different degrees of initiation because individuals (Jews and non-Jews) must ultimately believe in Jewish revelation and follow doctrines set down by the Jewish God as enshrined in the Jewish mythos. This is why I will argue that Noahidism is nothing more than the true lay order of Judaism, whereas Jews comprise the priestly class of this religion.

I want to flesh this out first by appealing to various primary texts in the Jewish canon and the primary Noahide literature. We can begin tracing the connection between Jews and Gentiles through the Jewish liturgy. The 'Aleinu' prayer expresses the primacy of the Jewish God in clear terms. We first read about the particularity of the Jewish people: "It is our duty to praise the Lord of all and to ascribe greatness to the Author of

\footnotetext{
138 Clorfene and Rogalsky, Introduction to the Noahide Laws, Chapter 5, Point 11.

139 "Accepting the Torah, but Remaining a Gentile." YouTube. October 29, 2008. Accessed October 5 , 2014. https://www.youtube.com/watch?v=5Irz8D6y40w.
} 
Creation who has not made us like the nations of the world, nor has placed us like other families of the earth, who has not made our portion like theirs nor our destiny like that of all their multitude ...."140 This concern with particularity is then juxtaposed with concern for all of mankind:

"Therefore, it is our hope, O Lord our God that ... all mankind will call upon Your name ... They shall accept the yoke of Your kingdom and You will reign over them speedily and forever. For the kingdom is Yours and to all eternity. You will reign in glory, as it is written in Your Torah ... The Lord shall be King over all the earth. On that day the Lord shall be One and His name One."141

The prayer undoubtedly calls upon Gentiles although it may be unclear to some readers just how they are expected to respond. Does accepting "the yoke of Your kingdom" imply conversion, or does this refer to observance of the Noahide laws? In any case, it is clear that Gentiles would ultimately believe the God of Israel is the one true God.

Excerpts like these indicate that Noahides will or should believe in the Jewish God, but it is interesting to note that no Talmudic source explicitly requires this of nonJews until late in Jewish intellectual and theological history. We should recall that the text of the Talmud only enumerates the seven laws and mentions nothing about belief in the Sinaitic dispensation, meaning this requirement is either found in another text predating or contemporaneous with the Talmud, or it is altogether a later addition to Noahide doctrine.

\footnotetext{
${ }^{140}$ Green, Universalism and/or Particularism, 2.

${ }^{141}$ Ibid., 2.
} 
There is one excerpt which implies Noahide belief in God, but it then fails to mention the Noahide laws:

Rabbi Eliezer stated: All non-Jews are denied a portion in the age to come, as it is written (Ps. 9:18), 'The wicked will return to Sheol, all nations who have forgotten God.' As to the phrase, 'The wicked will return to Sheol'this refers to the wicked Israelites. Rabbi Joshua argued: Had the text read, 'The wicked will return to Sheol, all nations' and ended there, I would have agreed with your opinion. Now that the text adds the phrase, 'all nations who have forgotten God,' I infer that there are righteous people (tzaddikim) among gentile nations who indeed merit a portion in the age to come. ${ }^{142}$

When taken with other statements, however, it is unclear just what Rabbi Joshua's exegesis means in this passage. Take Rabbi Joseph ibn Kaspi's assertion for example. He noted that "Against those famous saints of the gentiles (hasidei umot ha-olam) such as Aristotle and Plato we have no complaint and therefore our sages asserted concerning them that they have a portion in the age to come." ${ }^{143}$ This admission creates an ambiguity in Rabbi Joshua's analysis. Is belief in God equivalent to belief in the Jewish God, or may non-Jews attain salvation so long as they are theists or monotheists?

It is not until Maimonides' Mishneh Torah that belief in the Siniatic dispensation is explicitly codified as an article of faith for Noahides:

Anyone [i.e. any non-Jew] who accepts upon himself and carefully observes the Seven Commandments is of the Righteous of the Nations of the World and has a portion in the World to Come. This is as long as he accepts and performs them because (he truly believes that) it was the Holy One, Blessed Be He, Who commanded them in the Torah, and that is was through Moses our Teacher we were informed that the Sons of Noah had already been commanded to observe them. But if he observes them

\footnotetext{
142 Rosenthal, A Remarkable Concept, 468.

${ }^{143}$ Ibid., 473.
} 
because he convinced himself logically, then he is not considered a Resident Convert and is not of the Righteous of the Nations of the World, but merely one of their wise. ${ }^{144}$

This iteration limits Noahide belief to belief in the Jewish God and presumably Orthodox Jewish theology, which does not admit the existence of another Supreme Being. 800 years later, one text tells B'nei Noach that "It is the duty of a person to degrade and hold in contempt all other gods or any form of idolatry." 145 Another text chimes in saying, "Anyone who acknowledges that an idolatrous religion is true, even though he does not serve the idol, reviles the mighty and exalted Name of God." 146 The same authors also claim that "One who worships another deity besides the Creator denies the essence of religion and rejects the entirety of the Seven Universal Laws." 147

This point in the contemporary literature, which appears to be fairly concrete, is confused somewhat by other claims regarding Noahide belief in the same texts. Rabbi Sitzman claims that Noahides need not accept all of Jewish theology, but just how much is unclear. One would assume that to accept the Jewish God would be to accept everything understood about this being. It does not seem feasible that a Noahide could accept the divinity of Hashem and forego belief about the Divine attributes, nor does it seem likely that a Noahide would be allowed to believe in the Divine and hold it is finite, made of parts, only transcendent and not imminent, etc. It is possible Rabbi Sitzman is

\footnotetext{
${ }^{144}$ Reuven Brauner, trans. Laws of Kings and Wars: Translated from the Rambam's Mishne Torah, (Raanana: Talmudic Books, 2012), 8:14.

${ }^{145}$ Schwartz, Noahide Commandments, 9.

${ }^{146}$ Clorfene and Rogalsky, Introduction to the Noahide Laws, Chapter 6, Point 8.

${ }^{147}$ Ibid., Chapter 6, Point 1.
} 
telling Noahides it is unnecessary to concern themselves with these details, but this is only asking them to tacitly accept Jewish theology with their faith in Hashem. This would effectively dismiss the possibility for religious pluralism or inclusivism. This echoes Maimonides' and others' assertion that Noahides should only learn parts of the Torah which are necessary to understanding the laws of Noah. ${ }^{148}$ Determining this boundary is currently the work of the rabbis involved with the Noahide movement. From an academic perspective, it is well outside the scope of this research because it would require a thorough survey of Jewish law as well as Noahide law.

I also will not try to systematically describe or assemble a consistent theology for Noahides simply because this would, again, require an intensive survey of Jewish theology. We can be satisfied at the moment with noting that Orthodox rabbis require a specific kind of belief in the revelation of the Noahide laws; one must believe the laws are incumbent on humanity not as a matter of common sense, reason, or revelation to other religious traditions (i.e. through Christianity or Buddhism, etc.), but because the laws were commanded to Adam, Noah, and then to Moses at Sinai. What is more, the Jewish transmission of these precepts is the authentic medium through which the world can know of and follow the laws of Noah. These articles of faith bind Noahides to the Jewish mythos ${ }^{149}$ which should, by implication, commit them to Jewish theology if

\footnotetext{
148 Brauner, Laws of Kings, 10:11.

${ }^{149}$ I do not use the word 'mythology' pejoratively, but merely to denote a set of stories which communicate transcendent meaning(s).
} 
Noahides have any intention of being intimate with Orthodox institutions and practices.

Other rabbis have echoed Maimonides' codification. Noahides:

once they [Noahides] observe the seven commandments given to the descendants of Noah, in all their detail, [they] are considered righteous by virtue thereof. Under what circumstances is this true? When they observe the commandments and say, "[we observe] because our father Noah has commanded us that which God commanded him." 150

Plato and Aristotle, though at once accepted by Rabbi Joshua ibn Kaspi a few pages ago, would face some obstacles to their spiritual salvation, given that they were most likely unaware of the Sinaitic dispensation and thus unable to believe in the revelation of the Noahide laws. Interestingly, Rabbi Isaac Kook is rather sensitive to this issue. He does not agree that belief in the Jewish God is a principle of Noahide faith because he wants to avoid the "perceived problem of denying salvation to non-Jews who never heard of Mosaic legislation." "151 Norman Solomon also references Moses Mendelssohn who in 1773 wrote to Rabbi Jacob Eden of Altona with a similar concern.

And to me these matters are difficult ... that all the inhabitants of the earth from the rising to the setting of the sun are doomed, except us ... unless they believe in the Torah which was given to us an inheritance to the congregation of Jacob alone, especially concerning a matter not at all explicit in the Torah ... what will those nations do upon whom the light of the Torah has not shone at all? ${ }^{152}$

These opinions seem to be unfamiliar to contemporary writers like Rabbi Schwartz who is also unequivocal on this point. In line with contemporary Noahide thought on this

\footnotetext{
${ }^{150}$ Rakover, Noahide Obligation, 1078.

151 Stone, The Sinaitic and Noahide Law, 1169.

152 Norman Solomon, "Towards a Jewish Theology of Trilateral Dialogue," Islam and Global Dialogue, Religious Pluralism and the Pursuit of Peace, Aldershot (2005): 206.
} 
issues, he says that "In the category of the belief in the one true G-d, the seven commandments to the children of Noah include the prohibitions against worshiping other gods and against blasphemy (which includes professing atheism)."

Contemporary writers often try to deepen the importance of belief in the Jewish God by invoking metaphysics and psychology to express the practical, philosophical, and existential consequences of belief in the Jewish God; without believing in the Jewish God, they argue, the Noahide code cannot cannot confer any benefits upon the individuals who observe it, nor can the code be implemented as an effective ethical system. ${ }^{154}$ This notion is reinforced by Cowen and Schwartz who maintain that a conscious acceptance of the Jewish deity is the ultimate fulfillment of human potential.

A person who wants to do only those good deeds that he feels impelled to perform without being ordered to do so stresses his own importance. He thinks that he is the focus of everything. But when a person decides to carry out the Mitzvot because he has been ordered to by G-d, then he feels the importance of the G-d that orders. It is only then that he manages to discover and find all his hidden powers in order to carry out these mitzvot. These hidden powers cannot be tapped to their utmost if a person carries out the mitzvot simply because he has the sudden urge or mood to do so. ${ }^{155}$

Atheism essentially leads to moral narcissism and prohibits humans from tapping into their potential which is located beyond their own existence. Cowen makes it clear that observance of the laws as an imitation of the Godhead is crucial in self-realization. To be an atheist is to resist the truth regarding one's fundamental essence, it is to live in

\footnotetext{
${ }^{153}$ Schwartz, Noahide Commandments, 5.

${ }^{154}$ Weiner et al., Go(o)d for You, 6.

${ }^{155}$ Schwartz, Noahide Commandments, 4.
} 
ignorance, the consequence being that individuals fail to actualize their whole being. ${ }^{156}$ As if the prospect of losing out on the World to Come were not enough, Cowen presents imminent consequences for atheists.

And yet there are some thinkers who explore the possibility that atheism and the Noahide laws are compatible. One Noahide author, who will remain anonymous at his request, believes God is infinitely good, meaning it would be impossible for God to forsake anyone who correctly observes the laws of Noah, even if these individuals are atheists or follow the laws because they are rationally sensible. This view is not present in the literature. Cowen's view is common, that the laws have no force without the fear of God. Bar-Ron's text agrees with this point. ${ }^{157}$ There is also the notion that if God revealed the laws, it must mean belief in God is also a requisite for their proper observance, that is, belief in God is implied in the very act of receiving the laws from God. It would be similar to accepting the jurisdiction of a government after one assents to the laws set forth by it.

Yet another, arguably more popular position holds that the imitation of God, imitatio dei, is the fundamental principle which guides the proper observance of the Noahide laws. That is to say we are made in God's image. The laws themselves are a reflection of God's inner workings, from which it would follow that observing the laws of Noah would allow us to become more holy, to refine our divine nature. If an individual

\footnotetext{
156 Cowen, Universal Ethics, 175.

${ }^{157}$ Bar-Ron, Guide for a Noahide, 81.
} 
followed the Noahide laws but did not accept theism, that person would essentially reject the very purpose of the Noahide laws, presumably nullifying their spiritual effects.

Another argument in favor of Noahide deism comes from Rabbi Cowen's work. He identifies "a discussion in Noahide law as to whether humanity is obliged only to negate the opposite of belief in G-d - idolatry—or positively to believe in the focussed monotheistic concept of the unity of G-d." He goes on to say that "in either case this ethical imperative relates to an orientation towards G-d, which is one of belief." ${ }^{158}$ This argument fails to note that an atheist could prohibit themselves from being idolatrous and successfully observe the prohibition.

I also speculate there may be a Talmudic counterargument to the idea that the Noahide laws somehow imply or require deism. It is a commonly held rule of inference in Talmudic analysis that the differences between two laws, even if they concern the same topic, must indicate a nuance in the law. Thus, if we look at the first Sinaitic commandment, it instructs Jews to believe in the God of Israel positively, and to forsake all other deities. This law is strictly positive, whereas the Noahide laws are negative, telling us not to blaspheme or worship idols. The difference is clear. The negative commandments are telling us to avoid idolatry in all its forms, including fetishism. The prohibition of blasphemy is perhaps a general restriction on swearing by a god's name, or speaking negatively of any deity.

${ }^{158}$ Cowen, Universal Ethics, 169-170. 
This discrepancy between the negative Noahide laws and the positive Sinaitic laws has been accounted for in the chapter on law. As I explained then, many thinkers attempt to flesh out positive laws from the negative laws, which seems to me to be rather unscrupulous given the rule of inference just mentioned. But this is only a secondary issue in regards to this chapter. What is evident from this analysis is the exclusiveness of Noahidism. The primary sources show that Noahides and the Orthodox Jews involved with them do not see other religious traditions as valid. This belief is crucial to spiritual salvation and even self-actualization in mortal life.

Norman Solomon makes a similar argument, although without reference to the Talmudic rules of inference. He argues that

Modern writers often state that the Seven Commandments include 'belief in God'; this is careless representation of either the prohibition of idolatry or that of blasphemy. None of the extant early versions of the sheva mitzvot expressly demands belief in God. Why is this? Most probably because the rabbis were far more concerned with rejecting of idolatry than with the formulating definitions of God. An explicit demand for belief in God would have required some understanding, some definition, of God, and this was precisely the area into which the rabbis did not wish to enter. They asked only that the worship of idols cease and the worship of God be taken seriously and treated with respect; there was to be no emphasis on the substantive content of belief in God. ${ }^{159}$

He goes on to say that "It is the rejection of idolatry, and the respect for God-talk and worship, not the recognition of a defined divine authority, which is the foundation of Noahide law as conceived by the rabbis." "160 Solomon's contention is clearly one of intention. He believes the rabbis who originally codified and interpreted the Noahide

159 Solomon, Trilateral Dialogue, 204.

${ }^{160}$ Ibid., 205. 
laws were hoping that Noahide societies would at the very least be generous and hospitable to deists, regardless of their particular theological inclinations. But Solomon's argument also rests on an historical observation, namely that belief in god is a modern principle of Noahidism. I have outlined the same historical trend in this thesis, and it is curious that the contemporary rabbis have not.

I previously mentioned that belief in the Jewish God and revelation was first recorded in Maimonides' codification. Rosenthal verifies in an academic article that medieval commentators also did not codify the requirement of belief in revelation and the Jewish God within the Tosefta or the Talmud. ${ }^{161}$ Rosenthal subsequently notes that virtually all subsequent sages and scholars who analyze the issue of hasidei umot haolam (righteous gentiles) neglect to quote that extra requirement found in the Maimonides' Mishneh Torah. ${ }^{162}$ Joseph Karo, in his own rabbinic commentary, says that Maimonides' addition "was his [Maimonides'] own opinion, but that it is correct."163 Rosenthal also mentions that many rabbis believe Maimonides' intention has been misread in the passage where he codifies this principle. These rabbis believe he is merely referring to a ger toshav: "a resident alien who seeks the right to dwell under Jewish authority in Eretz Yisrael and who must accept the Noahide Laws as divinely ordained for that privilege." ${ }^{164}$ As such, this tenet would not apply to contemporary Noahides

\footnotetext{
${ }^{161}$ Rosenthal, A Remarkable Concept, 470, 475.

162 Ibid., 471.

163 Ibid., 470.

${ }^{164}$ Ibid., 470-71.
} 
because there is no Jewish theocratic state and therefore no way to implement the status of ger toshav.

\section{The Noahide in Jewish Eschatology}

The notion of personal spiritual salvation is also tied to the broader subject of Jewish eschatology. Like in the Aleinu prayer, Jewish eschatology reflects the primacy of the Jewish God who rules over Gentile and Jew alike. We can look at Isaiah 2:2-4 and Micah 4:1-3 (which are nearly identical), which describe how Gentiles will abandon their religious traditions and turn to Judaism for spiritual guidance, making Noahidism an exclusive religious movement.

In the days to come, The Mount of the LORD'S House

Shall stand firm above the mountains

And tower above the hills;

And all the nations

Shall gaze on it with joy.

And the many peoples shall go and say:

'Come,

Let us go up to the Mount of the LORD, To the House of the God of Jacob;

That He may instruct us in His ways, And that we may walk in His paths.'

For instruction shall come forth from Zion, The word of the Lord from Jerusalem. Thus He will judge among the nations And arbitrate for the many peoples, And they shall beat their swords into plowshares And their spears into pruning hooks: Nation shall not take up

Sword against nation;

They shall never again know war. ${ }^{165}$

\footnotetext{
${ }^{165}$ Isaiah 2:2-4 as read in Adele Berlin and Marc Zvi Butler, The Jewish Study Bible, Edited by Michael Fishbane (New York: Oxford University Press, 2004), 787-8.
} 
The implications of this passage from Isaiah seem to be far reaching. Not only will war cease to be a political reality, but peace would be a product of Jewish political and legal wisdom. The last third of this excerpt suggests that God (or a King inspired by God) will judge non-Jews despite their varying legal codes, or that one universal legal code will be implemented around the world. It is not surprising to find in the few texts written by Noahides affirmations that they are fulfilling these biblical prophecies today. ${ }^{166}$

\section{The Potential for Pluralism in Noahide Rhetoric}

I do not want to be disingenuous about the hints of pluralism or inclusivism found in the Jewish or Noahide worlds. There are cases in which Orthodox Jewish thought has rejected the concept of religious exclusivity, although this has only occurred sparingly, not systematically. Norman Solomon gives us one instance in which St. Paul says "There is no such thing as Jew and Greek, slave and freeman, male and female; for you are all one person in Christ Jesus." 167 This exemplifies the Christian notion that faith, as opposed to works, will yield salvation. The only significant distinction among human beings is whether one is a believer in Jesus Christ. Solomon points out a Jewish response to this position.

\footnotetext{
${ }^{166} \mathrm{I}$ would add as a side note, however, that the passage I have referenced from Isaiah is followed by a disavowal of the idolatry and unholy practices which Jewish custom had adopted from the Philistines and the "East," which is presumably Babylon. By contrast, the similar passage in Micah which I mentioned above is followed by a curious statement about non-Jewish faith: "Though all the peoples walk / Each in the names of its gods, / We will walk / In the name of the LORD our God / Forever and ever." (Micah 4:5) This passage is curious because it seems to predict that non-Jews will continue to follow their own gods, even in the time of messianic, worldwide peace-a pax iudaeica if you will.

${ }^{167}$ Galatians 3:28 as quoted in Solomon, Trilateral Dialogue, 207.
} 
"A rabbinic variant runs: 'I call to witness heaven and earth, that whether goy (gentile) or Jew, whether man or woman, whether manservant or maidservant, it is entirely according to the deeds of the individual that the heavenly spirit rests upon him'. This sentence cannot have been the model for Galatians 3:28, for none of its many versions is early enough. Rather, it is a comment, a reaction." 168

If behavior is indeed the emphasis of Judaism, then this would provide a wide ground for a true universal ethic that is not premised on the acceptance of any scripture or deism. As we have already seen above, however, this is not the case with Noahidism which clearly requires deism in a very specific sense. But contemporary Noahide literature still attempts to navigate pluralist and/or inclusivist rhetoric. One treatise written by Clorfene and Rogalsky on the Noahide code sets a pluralist tone in its introduction.

All the religions of the world, other than Judaism, approach the idea of unity with the precept, 'Believe as we believe, and the world will be one.' This approach has never worked. Judaism approaches unity from an entirely different perspective. It teaches that there are two paths, not just one. One path is yours. The other one is mine. You travel yours and I will travel mine, and herein will be found true unity: the one God is found on both paths because the one God gave us both. ${ }^{169}$

That there are two paths is true, but Judaism sets the bounds of both paths. Noahidism, just as much as any other world religion, implores others to "Believe as we believe, and the world will be one." They have essentially confused Judaism and Noahidism for two genera of religion when in fact they are two different species of the same genus. Even Rosenthal in his academic article values the Noahide/Jewish view of salvation as "one of

\footnotetext{
168 Solomon, Trilateral Dialogue, 207.

169 Clorfene and Rogalsky, Introduction to the Noahide Laws, Chapter 1.
} 
the most liberal doctrines about salvation in all religions." ${ }^{170}$ He later says "indeed, in all of the Western religions." 171 I think Stone's evaluation is more accurate when she says that the Noahide/Jewish code of law is one of the most pluralistic legal traditions. ${ }^{172}$

Dallen's work uses the language of secular politics when he refers to the revelation at Sinai as the "Hebrew Revolution." ${ }^{173}$ While his use of the phrase "Hebrew Revolution" does not suggest religious pluralism, it certainly does not suggest religious exclusivism. On the contrary, the concept of revolution also carries with it a sense of liberalism and plurality of possibilities. Dallen's purpose in using the phrase is to remark how the giving of the Torah markedly altered the course of human history. Chaos and immorality were subdued and in its place order and dignity were borne out of the proliferation of Jewish ethics.

Other writers arrive at a kind of inclusivism by attempting to fuse plurality and exclusivism. I quote Cowen at length to reveal the relative complexity with which he approaches this topic. He says that

The reconnection with transmitted universal law jars with modern, secular conceptions of human autonomy and freedom. Such a concept of freedom is 'freedom from.'... The true sense of freedom, in Frankl's words, comes where one 'submits him — or herself - freely — to a law. Responsibility is thus even more so a binding-back together of freedom, a recoupling with a (higher) order in the sense of law.' ...Freedom in the sense of 'freedom from,' still however retains a virtue for Noahide theology, in the sense of a

\footnotetext{
170 Rosenthal, A Remarkable Concept, 467.

${ }^{171}$ Ibid., 468.

172 Stone, The Sinaitic and Noahide Law, 1157.

${ }^{173}$ Dallen, The Rainbow Covenant, xii.
} 
freedom to register individual particularity in relation to the performance of an abstract moral norm. ... Without violation of the Divine norm, it is possible for the individual to perform it in a way which expresses his or her own unique personality and sensibility. ${ }^{174}$

His analysis invokes Viktor Frankl's view on freedom which is not novel and can be traced back to the Enlightenment, but its invocation plays a clear role. Cowen is saying that submitting oneself to the Noahide laws is no 'freedom from' in the classical sense, but that there is a great degree of freedom in determining how to enforce the laws. This is again, as Stone points out, legal (or I would also argue non-religious cultural) pluralism, not religious pluralism.

But as I suggested earlier, these contemporary texts very quickly return us to a position of exclusivity. Clorfene and Rogalsky, whose introduction two pages back seemed to pave the way for inclusivism at the very least, require obedience to rabbinic authority. They say

The hurdle that must be cleared in preparation for observing the Seven Noahide Commandments is the acceptance of the idea that mankind's way to the Father is through the rabbis. Rebellion against the sanctity of rabbinic authority and tradition has been with us since those first days in the Wilderness of Sinai when the followers of Korah led a revolt against absolute rabbinic authority, as we learn in the Torah, 'And they assembled themselves against Moses and against Aaron and said to them, You assume too much; for the whole of the congregation are all of them holy, and the Lord is among them; wherefore then will you lift yourselves up above the congregation of the Lord? ${ }^{175}$

So again, the Noahide Laws are not a universal ethic, but part and parcel of the Jewish belief system. Now I would like to point out that this example is not a solid proof text for

${ }^{174}$ Cowen, Universal Ethics, 31.

${ }^{175}$ Clorfene and Rogalsky, Introduction to the Noahide Laws, Chapter 1. 
Noahide loyalty to rabbinic authority. The people revolting against Moses' authority are Jews, not Noahides or Gentiles. ${ }^{176}$ If Gentile adherence to rabbinic authority is necessary, then Judaism and Noahidism are just as monolithic as any other religion. Indeed, Clorfene and Rogalsky insist we "accept the rabbis...for the source of understanding the Seven Noahide Commandments is found in the Talmud and the later rabbinic teachings, and nowhere else."177

Cowen makes another apparent appeal to inclusivism in the form of a rabbinic parable in which Abraham gifted sacred knowledge to his sons, born to him of Ketura (or Hagar). Cowen cites Rabbi Menasheh ben Israel's work, Nishmas Chayim, which claims that Abraham sent these sons east with this knowledge which formed the basis of the Eastern religions. He draws attention the word "Brahman," the spiritual principles of Hinduism, and its similarity to the name "Abraham."178 The correlation Cowen wants to make is important to the religious unity of mankind. He says that "Together with this common spiritual heritage comes the ability to 'hear' a common set of root values which, in their pure original expression, are the Noahide laws." ${ }^{179}$ And still later in his work he is confident "there is a strong reason to believe that this Noahide template could be extended to, and find resonance with, Hindu, and possibly also Buddhist traditions,

\footnotetext{
176 See Num. 16 for the story of Korah.

177 Clorfene and Rogalsky, Introduction to the Noahide Laws, 2.

178 Cowen, Universal Ethics, 4.

${ }^{179}$ Ibid., 5.
} 
inasmuch as these also have a connection with the historical Abraham and the tradition transmitted by him." 180

But this idea of extension is vague. Does Cowen's idea of extension imply pluralism whereby the spiritual validity of Hinduism is recognized so long as Hinduism upholds the Noahide laws? Or do the Noahide laws serve as a way to subsume the Hindu religion? I think the last clause of Cowen's quote provides a hint. He accepts Hinduism's spiritual validity "inasmuch as these [religious traditions] also have a connection with the historical Abraham and the tradition transmitted by him." But if Hindus must trace their lineage to Abraham as the patriarch of their religious tradition, why stop there? Would not the next logical step be to embrace Abraham's other principles and eschew belief in the Hindu deities (of which there is plenty in the Hindu religion(s)) for faith in the Jewish God? Cowen's qualification strikes me as a way to draw people away from their religious traditions towards what he believes is the true source of spiritual wisdom: Judaism.

I think just about every contemporary Noahide text agrees on this point in their own way. Rabbi Bar-Ron admits that while it is possible for adherents of other religions to fall within the letter of the Noahide laws, it is incorrect to label these religions as Noahide religions. ${ }^{181}$ In fact, Bar-Ron's own work demonstrates the centrality of belief in the Jewish God. In the same pages I just cited, he remarks how Muslims and Christians,

\footnotetext{
${ }^{180}$ Ibid., 90.

${ }^{181}$ Bar-Ron, Guide for the Noahide, 33, 58.
} 
although not worthy of being considered Noahides, do merit the World to Come. Bar-Ron has carried this on from Maimonides' work, and it is echoed in Cowen's work. ${ }^{182}$

And like in many other contemporary Noahide texts, Rabbi Bar-Ron attempts to emphasize the pluralism he feels is inherent in Noahidism by criticizing Christian absolutism. He asks us to

Consider Jesus' restrictions on God's general love for those who observe His Commandments. He reportedly taught: 'He who believes in the Son has everlasting life. But he who does not believe in the Son shall not see life, but shall suffer the everlasting wrath of God.' (John 3:5) 'I surely say to you: Unless a man is born of water and the Spirit [undergoes full conversion to his religion], he cannot enter the Kingdom of God.' In other words, if one does not believe in Jesus, one has no place in the World to Come (eternal life). ${ }^{183}$

Bar-Ron sees Christianity's principles of faith as restrictive and he counters by citing the Tosefta, Tractate Sanhedrin 13 which declares that "The righteous of all nations have a place in the World to Come." And he goes on in the same vein citing a midrash which, like many other pre-Maimonidean opinions, reads pluralistic: "I bring heaven and earth to witness that the Divine Spirit rests upon a non-Jew as well as a Jew, upon a woman as well as upon a man, upon a maidservant as well as a manservant. All depends on the deeds of the particular individual."184

With these two quotes, Bar-Ron has certainly appealed to the notion of universal ethics devoid of belief in particular religious truths. Righteousness is dependent upon

\footnotetext{
182 Cowen, Universal Ethics, 183-86.

183 Bar-Ron, Guide for the Noahide, 148.

${ }^{184}$ Ibid., 149.
} 
acts, not belief in purported historical facts. But in keeping with Maimonides' codification, Rabbi Bar-Ron agrees that salvation is attainable only if one adheres to the Noahide laws "specifically because HaShem commanded them in the Torah, and informed us through Moses that the nations had been commanded them originally." ${ }^{185}$ In short, the Christian passages Rabbi Bar-Ron cites are not more absolutist or indicative of exclusive religion than the Rabbi's own writing. Jesus and John are asking nothing more than what Rabbi Bar-Ron is asking of Noahides; believe in the son, and you will inherit the world to come; believe in the Noahide laws as being revealed to Moses, and you will inherit the world to come. And still Bar-Ron, like many other contemporary Noahide writers, insist upon some elusive notion of Noahide and Jewish pluralism.

I do not think I am wrong for being so critical of contemporary Noahide texts on this issue. I hold no contempt for these authors or the Noahide movement, nor do I believe there is an attempt (orchestrated or not) to deceive Noahides and others, but I do think it is important to point out this rather odd and contradictory aspect of Noahide identity. The allure of universalism in contemporary Noahidism cannot be questioned, so one must wonder how people can simultaneously hold two positions which are at such odds with each other. I hope the reader would agree with me as I agree with Novak that "much of what could be termed 'Jewish universalism' is the hope of a kind of 'judaizing' of the world, as it were." ${ }^{186}$ Noahidism is a part of the Jewish tradition. It is clear from rabbinic writings on Noahidism that they see the movement as their brain child and many

\footnotetext{
185 Ibid., 2.

${ }^{186}$ Novak, Natural Law in Judaism, 189.
} 
Noahide texts on the matter concur. Hanke, herself a Noahide, sees "This movement is a tandem hang glider shared by Jews and Gentiles."187

\section{Noahidism as a Lay Tradition}

I think the characterization of Noahidism as a lay tradition of Judaism is conceptually true, even if it has not yet been born out in reality. We should remember that Noahidism is a very new movement and has not yet gained acceptance in every Orthodox Jewish congregation. Additionally, not all lay traditions function in the same way, although there are conceptual similarities between each. Lay traditions tend to incorporate a lighter regimen of religious ritual and ceremony than their respective priesthoods or monkhoods. Lay traditions are also not exposed to the same sacred knowledge, whether in depth or amount. The priesthood concerns itself with engaging in the most rigorous rituals as well as understanding and passing on the most profound knowledge. We can define the difference between the laity and priesthood in most religious as one of access. Priesthoods tend to have access to the most sacred knowledge, ritual, and spaces than the members of the laity.

Within Judaism, the concepts of laity and priesthood are rather complex. The priestly class is traditionally formed by two groups of people: the Levites and the Kohahim. These two groups received their ordination directly from God, who chose the Levi and Kohen tribes to oversee the Ark of the Covenant, sacrifices, and services in the

\footnotetext{
${ }^{187}$ Hanke, Turning to Torah, x.
} 
Temple of Jerusalem. ${ }^{188}$ The ritual sacrifices required by God must be submitted by these two groups and no one else. Additionally, these groups were differentiated from the rest of society in a socio-economic manner. For example, the Torah prohibits them from owning land. Yet, to ensure their survival, society must contribute a percentage of its economic output to these groups.

Today, the Levites and Kohanim do not serve the same function in Jewish society because the Temple and the Ark do not exist. The destruction of the Temple(s) of Jerusalem and the subsequent diasporas displaced the Jewish priestly class. The structure of Jewish society had to be reconfigured if in order to ensure the propagation of sacred knowledge to subsequent generations. But the Jewish population was also concerned with deriving new forms of worship now that the primary form, Temple sacrifice, had been made impossible. The rabbinic class was part of the response to both dilemmas. To be clear, however, the rabbinic class is not technically the priesthood of the Jewish people. Although they do serve several official functions within the Orthodox Jewish world, they do not possess Biblical authority in the same way the Levites and Kohen do.

The rabbis serve primarily to interpret the Talmud and apply its doctrine to the new environmental contexts which Jewish communities encountered in exile. Rabbis traditionally oversee other community functions, such as the implementation of kosher laws, officiating wedding ceremonies, leading congregations in communal prayer and rituals, among other things. So while the rabbi class does not form the official priesthood

\footnotetext{
188 The Kohanim were ordained in Numbers 25:7-13. The Levites merited their religious duties in Exodus 32:26-29. Their specific duties are enumerated in various places throughout the Pentateuch.
} 
of Orthodox Judaism, there is an implicit tendency to view the rabbis as a pseudopriesthood because they are better trained to deal with religious matters. On the other hand, Jews who are not rabbis form the laity. This is a reasonable perspective, but the inclusion of the Noahidism in the Orthodox Jewish fold requires a return to the traditional taxonomy of the Jewish people. And this is where the status of the non-rabbi Jew becomes key important.

The non-rabbi Jew is distinct from the Noahide in many ways. Only Jews can be rabbis, a fact which sets them apart from Noahides. Additionally, all Jews are commanded by God to observe rituals, holidays, and understand Torah knowledge which Noahides are not privy to (more on this in the coming chapter on ritual). While the status of the unordained Jew is akin to what we would consider a laymember, they are still at a great remove from the Noahide who is also welcomed into the Jewish congregation and community. But most importantly, the entire nation of Israel is viewed by God as a "nation of Priests." 189 This means that while the Levites, the Kohanim, and the rabbis all serve special functions among the Jewish people, the Jewish people themselves are distinct from all other nations of the world. The nation of Israel itself is a priesthood. This fact indicates that Noahidism is indeed the lay movement of Orthodox Judaism.

This evaluation is echoed in the Noahide primary literature. The relationship between Noahidism and Orthodox Judaism is made clear from a contemporary Orthodox standpoint. Clorfene and Rogalsky, like various other texts, claim that "The Mosaic and

\footnotetext{
189 Schwartz, Noahide Commandments, 4.
} 
Noahide Laws were inextricably bound together. The Children of Noah, the righteous

Gentiles, were obligated to fulfill the Seven Commandments because they were given on Mount Sinai, not because they were given to Noah." 190 In the same text, they openly refer to Noahides as laymen: "This was the beginning of the true universal religion in which Israel, the Jewish people, is the priest and the Children of Noah, the righteous Gentiles, its faithful laymen." 191 And I quote them once again at length to assure this is not a misprint on Clorfene's or Rogalsky's part. Their insistence on this point is sincere. They believe

The Children of Noah are co-religionists of the Children of Israel. Together, they are peaceful partners striving to perfect the world and thereby give God satisfaction. By viewing himself as a Noahide, the Gentile becomes like the Jew, in that he is a member of a people whose peoplehood (not just his religion) is synonymous with its relationship to God.

The intention was for the Jewish people to proclaim the faith in the God of their fathers and to bring all the peoples of the world into the communion of God and Israel by teaching them the Seven Commandments of Noah. ${ }^{192}$

Another author, while not explicitly naming Noahides as laymen, remarks that "Part of the Torah was given on Mount Sinai to the Israelites as a Holy Nation of Priests." 193 This is not an uncommon way of referring to the children of Israel.

\footnotetext{
190 Clorfene and Rogalsky, Introduction to the Noahide Laws, Chapter 2.

${ }^{191}$ Ibid., Chapter 2.

192 Ibid., Chapter 2.

193 Schwartz, Noahide Commandments, 4.
} 
It is safe to say that Orthodox Jews and Noahides agree on the status of the Noahide movement and that there is no reason to contest their agreement. But it is important to look at it from the perspective of social science and see if their evaluation is correct. I think Noahidism cannot be defined in any other way except as the lay movement of Judaism. Using Weber's definition of a sect and a church, Noahidism is certainly not a sect. Its membership is not limited to some type of selective conversion. ${ }^{194}$ We can also apply Troeltsch's view that sects often reject the predominant social order and its worldliness, whereas the church often may try to influence and become a part of the social order. ${ }^{195}$ Noahidism embraces the worldliness of Judaism and its constructs and it simultaneously seeks to reform the social order through the implementation of the Noahide laws. If Noahidism does in any significant way reject the current social order in any given community, it is presumably not by its own volition, but by the guidance of Orthodox Judaism.

We cannot deem Noahidism a cult or a sect because it is not deviant either in practice or belief from Orthodox Judaism. ${ }^{196}$ It may seem to some like a sect because it lacks cultural or societal prominence and in many ways challenges previous notions of

\footnotetext{
${ }^{194}$ Max Weber, Peter Baehr, and Gordon C. Wells, The Protestant ethic and the "spirit" of capitalism and other writings (New York: Penguin Books, 2002), 211.

195 Stephen Hunt, Alternative religions: a sociological introduction (Aldershot, Hampshire, England: Ashgate, 2003), 35.

${ }^{196}$ Irving Hexham and Karla O. Poewe, New religions as global cultures: making the human sacred (Boulder, CO: Westview Press, 1997), 36.
} 
Jewish and non-Jewish identity, but in the eyes of Orthodox Judaism, Noahidism is very much a church, that is, an organization with conventional religious beliefs. ${ }^{197}$

It also fails to fit into Stark and Bainbridge's typology of cults. Not only does Noahidism not provide cultural innovation, a novel system of compensators, costs, or rewards, but it does not even present a new interpretation of standing doctrine. ${ }^{198}$ Its lack of a charismatic figure and community make it an audience based movement where the interaction between leader(s) and congregation is not of central theological importance.

For our purposes, we should also label the contemporary Noahide movement as a new modern religious movement and even go so far as to call it a global movement, not merely because it has adherents on every hospitable continent, but because it espouses transnational and transcultural belief in one deity. It offers a global vision and aims to achieve a radically new world culture. ${ }^{199}$ While this global vision has always existed dormant in Judaism, it is Noahidism that is putting such a notion into practice. Although unlike new, modern religious movements, it does not embrace the synthesis of religious beliefs and practices, but hearkens back to a conservative position. This is clear I think in its own right, but perhaps it is better we compare Noahidism to Messianic Judaism. The former has its doctrine and practices set down by Orthodox Judaism whereas the latter combines Jewish lineage and the Abrahamic and Mosaic covenants with belief that Jesus Christ was the messiah and that he is set to return once more.

\footnotetext{
${ }^{197}$ Ibid., 36.

${ }^{198}$ Hunt, Alternative Religions, 20-3.

${ }^{199}$ Hexham and Poewe, New Religions as Global Cultures, 46.
} 


\section{CHAPTER 4}

\section{IDENTITY AND NOAHIDE RITUAL}

So far we have dealt with Noahide law and notions of pluralism or inclusivism within the movement. Noahide law is undoubtedly the crux of Noahide ideology and identity, making it important to understand before looking at other distinct features of contemporary Noahidism. The various interpretations of Noahide law (as we saw in Chapter 1) influence contemporary attitudes of religious pluralism among practitioners and leaders. Initial portrayals of Noahide law and philosophy depict a universal, nondogmatic view of ethics open to practitioners of all religions. Closer investigation uncovers quite a different picture. Noahide ritual, or the lack thereof, also appears to reflect the supposed universalism of Noahidism. Some proponents of Noahidism would have us believe that without a ritual tradition, Noahidism can hardly be called a religion. This is not only untrue, but contemporary developments in Noahide ritual also point towards the formation of an exclusive religious movement more akin to Orthodox Judaism.

This chapter is dedicated to investigating how the poverty of Noahide ritual affects contemporary Noahide individuals and the movement on the collective level. We can examine first the halakhic limitations on Noahide ritual and then move on to the various innovations Noahides have implemented in order to circumvent these prohibitions in order to bring the symbolism and meaning of ritual into their daily lives. 


\section{The Halakhah on Ritual}

The halakhic stance on Noahide ritual is another aspect of Noahide identity that is incredibly unstable. Most texts on the issue present their ideas definitively, although there are a great number of opinions in the contemporary sources. One cannot help but sympathize with Noahides on this point because ritual is most often a critical aspect of religious life. There are only a few rabbis who are generous in their advocacy of Noahide ritual. Righteous gentiles usually face serious limitations on the ways they are allowed to worship:

In accord with the Seven Universal Commandments, man is enjoined against creating any religion based on his own intellect. He either develops religion based on these Divine Laws or becomes a righteous proselyte, a Jew, and accepts all 613 commandments of the Torah. (Note: Concerning making holidays for themselves, Noahides may participate in the celebration of certain Jewish holidays, such as Shavuot, celebrating the Giving of the Torah, since the Children of Noah received their commandments at the same time, or Rosh Hashanah, the Jewish New Year and Day of Judgment, since all mankind is judged by God on that day, so it should therefore be important to the Noahide as well as the Israelite. Rosh Hashanah is also the day that Adam, the First Man, was created by God, and all mankind is descended from Adam just as it is from Noah. Even these, however, the Noahide celebrates only in order to bring additional merit and reward to himself, and he may not rest in the manner of the Jews. Moreover, the Noahide is strictly forbidden to create a new holiday that has religious significance and claim that it is part of his own religion, even if the religion is the observance of the Seven Noahide Laws. For example, it would be forbidden to make a holiday celebrating the subsiding of the waters of the Flood of Noah or anything of the like. And, all the more so, it would be forbidden to institute holidays that ascribe religious significance to events outside the purview of the Seven Noahide Commandments. Celebrating secular activities and commemorating historical events, even if they involve a festive meal, are permissible.). ${ }^{200}$

\footnotetext{
${ }^{200}$ Clorfene and Rogalsky, Introduction to the Noahide Laws, Chapter 5, Point 24.
} 
Bar-Ron's own writing agrees with this position for the most part. ${ }^{201}$ Dallen also concurs and even provides a proof text from Isaiah, who prophesies that Gentiles will make religions in honor of the God of Israel, but this will warrant nothing other than punishment. ${ }^{202}$

The rules on Noahide ritual do permit the performance of some rituals, although there is a significant caveat. As we saw above, the Noahide may celebrate Jewish holidays, although they cannot abstain from labor as the Jews do. For example, a Noahide may choose to take Saturday off for leisure activities, the study of Torah, meditation, or any other kind of respite, but he/she must violate at least one of the Sabbath laws so as to not mimic the Jewish Sabbath. ${ }^{203}$ Additionally, the Noahide must have a specific intention while observing Jewish ritual. The Noahide should not impose these customs upon themselves under the premise that God has commanded them, but merely to bring themselves more merit and benefits, although it is unclear whether this means spiritual or earthly merit. To claim these customs or holidays were commanded to Noahides is tantamountount to proclaiming a new revelation, which in turn is the establishment of a new religion. ${ }^{204}$

\footnotetext{
${ }^{201}$ Bar-Ron, Guide for the Noahide, 57-60.

202 Dallen, The Rainbow Covenant, 250. See Isa. 19:19-21 for the prooftext.

${ }^{203}$ Bar-Ron, Guide for the Noahide, 59.

${ }^{204}$ Cowen, Universal Ethics, 164.
} 
One can find points of disagreement between authors in both general and specific terms. For example, Rabbi Bar-Ron permits the wrapping of tefillin and the fixing of a mezuzah. ${ }^{205}$ By contrast, Rabbi Schwartz prohibits Noahides from celebrating the sabbath, using tefillin and placing mezuzoth. ${ }^{206}$ Rabbi Clorfene takes another tack altogether and interprets the biblical vocabulary used to refer to non-Jews and concludes the Sabbath, tefillin, and mezuzoth are indeed permissible to Noahides. ${ }^{207}$

It is unclear at the moment how popular Rabbi Clorfene's work has been and how much influence it has wielded in the Noahide world, but I am compelled to assume it is a welcomed endorsement of a robust Noahide ritual tradition. Noahides have for some time expressed great disappointment in the lack of ritual. Hanke expresses herself unequivocally, saying she "found this lack of religious ritual and practice for ancient Noachides to be unsettling."208 J. David Davis' autobiographical account expresses how difficult some of his congregation members found it to be Noahides because of the lack of ritual. His theory, and I am inclined to agree, is that his members were once devout Christians who had a great number of rituals to celebrate, from Christmas, to Easter, and so forth. Without new rituals to replace their Christian ones, his congregation members came to feel a void in their spiritual lives and became nostalgic for their old religious

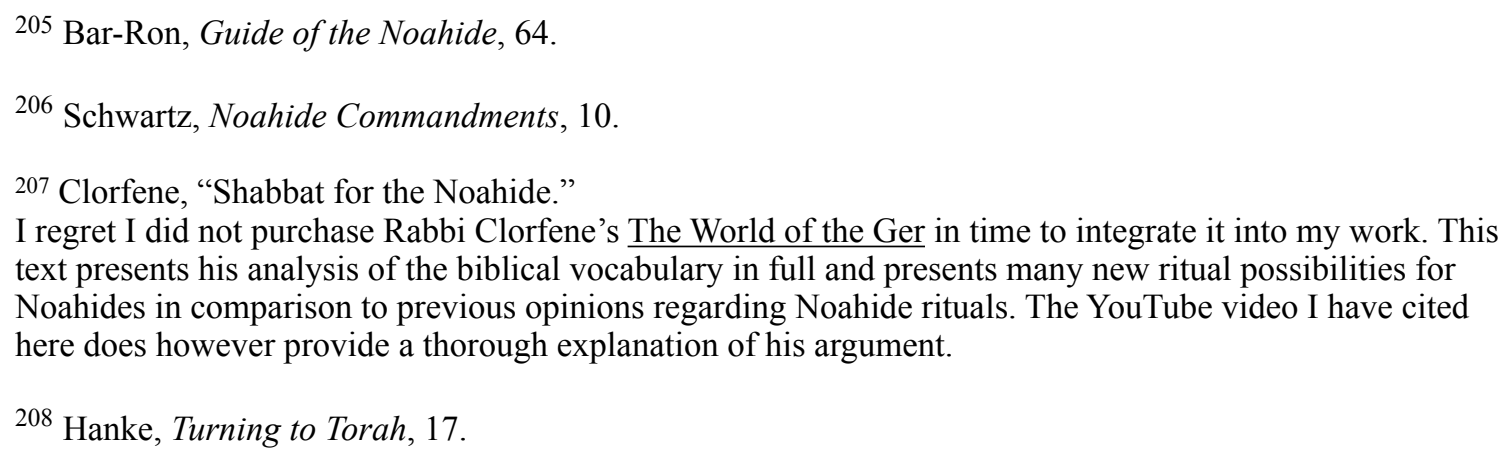
text presents his analysis of the biblical vocabulary in full and presents many new ritual possibilities for Noahides in comparison to previous opinions regarding Noahide rituals. The YouTube video I have cited here does however provide a thorough explanation of his argument.

${ }^{208}$ Hanke, Turning to Torah, 17. 
identity. ${ }^{209}$ I make this point again later in the chapter on conversion (and perhaps a bit more robustly) because of the effect which conversion could have on the Noahide psyche. A rigorous conversion process could help shift the convert's mind away from their previous religious affiliations into a strong identification with Noahidism.

My own survey shows that Noahides generally feel there are not enough resources for them to understand different aspects of their religious lives. Respondents were asked to describe how they felt about the scarcity or abundance of resources which help them enrich their spiritual lives. These resources were divided into four categories: resources for prayer, for celebrating holidays, for understanding Noahide law, and for understanding Noahide ethics. In each category, a majority felt more resources were necessary. ${ }^{210}$

Community generally plays a large role in the formation of ritual and the development of resources to promote Noahide ritual. Jewish theology admits that community is an important aspect of Jewish life. In fact, a study conducted in1992 shows a strong correlation between "community size and formal participation in the Jewish faith." ${ }^{111}$ While this is not directly applicable to Noahides because they do not share the same socio-economic and demographic history of religious and ethnic Jews, the study may imply the importance of locality in strengthening bonds to Jewish concepts, practices, and world-views. There is a disparity in the Noahide world with regard to

209 J. David Davis, Finding the God of Noah: The Spiritual Journey of a Baptist Minister from Christianity to the Laws of Noah (Hoboken, NJ: KTAV Publishing House, 1996).

${ }^{210}$ Noahide Individuals Survey, Question 21.

${ }^{211}$ Hunt, Alternative Religions, 210. 
community bonding. Of the $250+$ respondents, only 48 claim they participate with their local Jewish community. ${ }^{212}$ Question $15 \mathrm{~A}$ of the survey shows that of these 48 , very few participate on a consistent basis. ${ }^{213}$ Of another 48 respondents who have no relationship with a Jewish community, more than $62 \%$ expressed a desire to pray, celebrate holidays, and attend sabbath services at Jewish synagogues..$^{214}$

The proximity of Jewish communities to Noahides is not the only issue. Noahides are also so scant and spread around the world that there are not very many physical Noahide communities. 139 participants reported activity in online Noahide communities, while only 48 reported activity in physical communities ${ }^{215}$ and only 28 interact with Noahides in person at least once a month. ${ }^{216}$

I suspect (and perhaps knowledgeable Noahides and Jews would agree) there is a communitarian aspect to Jewish theology and practice and, by association, to Noahide theology and practice. I would contrast this to the various New Age movements which emphasize personal physiological and psychological health as well as the realization of spiritual self-expression. New Age movements and their organizations are usually capable of disseminating their beliefs and practices on an individual basis through what Hunt calls "client and audience cults." 217 In these movements, "adherents to these movements

\footnotetext{
212 Ibid., Question 14.

${ }^{213}$ Ibid., Question 15A.

${ }^{214}$ Ibid., Question 15B.

${ }^{215}$ Ibid., Question 18.

${ }^{216}$ Ibid., Question 24.

${ }^{217}$ Hunt, Alternative Religions, 90.
} 
do not constitute a membership in any meaningful sense, but are customers who are often literally buying a 'service' such as healing or realizing personal abilities."'18 Jewish conceptual and ritual artifacts, on the other hand, may simply require more digestion and often in a group setting. The complexity of the Talmud and the various communal methods used to study it, I think, would be a testament to the importance of community in Jewish learning and practice.

I do not have enough ethnographic data to explain the lack of interaction between Noahides and Jewish communities, although the issue is not lost on the primary literature. Rabbi Bar-Ron and others recognize the difficulties facing Jewish synagogues when the time comes to take in Noahides. There is a general lack of resources in Jewish communities to support Jewish activities, let alone Noahide activities. Just as with conversions, having Noahides highly involved in Jewish communities also brings the risk of introducing idolatrous ideas to the group. ${ }^{219}$ Furthermore, Bar-Ron and Dallen note that the laws of Noah are not a topic which rabbis must cover for their ordination, and this often makes it difficult for rabbis to cater to Noahide needs and thirst for guidance. ${ }^{220}$ There is also the threat of intermingling between a great number of single Jewish individuals and single Noahides, ${ }^{221}$ not only because there are so many single Jews, but

\footnotetext{
218 Ibid., 90.

${ }^{219}$ Bar-Ron, Guide for the Noahide, 146.

220 Ibid., 146.

Also see Dallen, The Rainbow Covenant, viii.

${ }^{221}$ Bar-Ron, Guide for the Noahide, 145.
} 
because it is so difficult for Noahide singles to find suitable mates. ${ }^{222}$ This inability to find a stable community places Noahides in a kind of limbo where they cannot be completely absorbed by the Jewish community or a community of their peers, and thus they cannot successfully or happily cut themselves off from their previous cultural or religious affiliations. ${ }^{223}$

To deal with these conditions, Noahides have had to be innovative. Because there is no unanimously sanctioned, halakhic way for Noahides to engage in significant ritual activity, they (Noahides and Jews alike) have explored concepts and behaviors which help Noahides extend their sense of ritual so that the sacred can have a place in their daily lives.

\section{Ethical Precepts as Ritual}

Contemplating and consciously applying ethical precepts to daily activities and decisions are some ways individuals can bring a sense of spirituality to bear on their otherwise mundane reality. Repentance is one such concept and is a viable alternative to our common conception of ritual because it is personal, private, and does not require community. Bar-Ron and Clorfene and Rogalsky advocate its importance in the life of the Noahide:224

If any one concept epitomizes the knowledge of God, it is Judaism's belief that man can achieve complete repentance. Judaism does not even find the word repentance sufficient, for repentance presupposes a natural state of

\footnotetext{
222 Hanke, Turning to Torah, 22.

223 Ibid., 21.

${ }^{224}$ Bar-Ron, Guide for the Noahide, 61.
} 
sinfulness from which, in reality, there is no return. The Jewish idea is called tshuvah, return. ${ }^{225}$

Repentance can be attained by prayer, which is permissible and will be discussed later on. The primary literature suggests a number of other values which Noahides should be mindful of throughout their day and in the course of the Jewish calendar year. For example, Yom Kippur should be a day of repentance, Hanukkah should be a celebration of "the victory of Judaism over Hellenism," and Passover should be a celebration of human freedom. ${ }^{226}$ Indeed, one Noahide has written that while he is able to clean out his house and avoid unleavened bread during Passover, he is more inclined to follow a rabbi's advice and focus on contemplating the complexity and significance of human freedom. ${ }^{227}$

I think this emphasis on the individual's ability to contemplate important ethical values is an interesting rhetorical choice. This activity does, in a way, replace ritual and brings substance to one's spiritual journey. Some writers may also be aware of the fact that most readers are probably ex-Christians, for whom repentance and redemption are key concepts. Clorfene and Rogalsky’s text, for example, enumerates many different ways to attain repentance, even before going through the details of the Noahide laws. ${ }^{228} \mathrm{I}$ think implicit in this emphasis on contemplating concepts like redemption and human

\footnotetext{
225 Clorfene and Rogalsky, Introduction to the Noahide Laws, 21.

226 Schwartz, Noahide Commandments, 13-4.

227 Richard Mather, "Noahides and the Celebration of Passover." Arutz Sheva, March 31, 2013, Accessed April 6, 2015, http://www.israelnationalnews.com/Articles/Article.aspx/13069.

${ }^{228}$ Clorfene and Rogalsky, Introduction to the Noahide Laws, 23-5.
} 
freedom is a shift away from ritual in the sense of positive, predetermined behavior in favor of active thinking about these ideas and scrutinizing daily, common behavior against the backdrop of Jewish values.

\section{Torah and Contemplation}

This preoccupation with ethical contemplation has in fact turned into a ritual of its own in the form of Torah study, although it is difficult to tell which came first, the chicken or the egg. Noahides are encouraged to analyze the Torah and extrapolate ethical precepts which they could apply to their daily lives. So popular is this as a form of ritual among Noahides that numerous online yeshivot (religious schools) have been started for the study of Talmud, Torah, and other rabbinic sources. One statistic from my survey shows that 111 of 193 respondents (58\%) study related texts daily, while another 47 respondents (24\%) claim they study at least 2-3 times a week. ${ }^{229}$ Another question on the survey asked Noahides to identify which activities they would participate in if they could interact with a Jewish community. Out of 48 respondents, 43 replied they would like to study in a Jewish community. Studying was the most popular activity - in second place was celebrating the sabbath, with 37 of 48 respondents chiming in. ${ }^{230}$ I would go so far as to conjecture that study, in both its communal and individual context, is the most meaningful ritual Noahides have at the moment in the sense that it strengthens individual and communal identity apart from the predominant culture. Or to put it in Hanke's words,

\footnotetext{
${ }^{229}$ Noahide Individuals Survey, Question 23.

${ }^{230}$ Ibid., Question 15B.
} 
Noahides must "unlearn the lessons taught in the church that kept us in idolatry and away from true monotheism." 231

Intensive and consistent communal and individual study makes Noahides more intimate with the Jewish mythos and worldview. Myth is a powerful instrument in the formation of religious communities and identity. For the individual, myth has the power to validate primary/numinous experience. Here we can understand Hexham and Poewe's distinction between story and myth. A myth is a culturally formative story that provides information about a person's relationship with the sacred.232 Take for example the narrative in Genesis where all of mankind has a significant level of interaction with God, but also how that relationship, which exists very much at the macro level, is degraded over time with the Flood and the Tower of Babel. These stories provide a very intense background against which contemporary Noahides can interpret their reality. But it is perhaps on the collective level that it is most important, because study and contemplation on a communal level gives individuals an opportunity to interact in a meaningful way. Individuals can test their knowledge and understanding of the Jewish mythos, express their individual interpretation of the mythos, and form bonds with other individuals from their shared understanding or even their disagreement and dialectic. Hanke agrees with my assessment, that study is the most important form of engagement for Noahides. ${ }^{233}$

\footnotetext{
${ }^{231}$ Hanke, Turning to Torah, 36.

${ }^{232}$ Hexman and Poewe, New Religions as Global Cultures, 81.

${ }^{233}$ Hanke, Turning to Torah, 26.
} 
This is not only because of its social benefits, but also because the principles found in the Hebrew Scriptures are the cornerstone of human society and divine retribution attributed to their violation, even if they are not explicitly mentioned in the Torah or Talmud as Noahide commandments. ${ }^{234}$ Noahides are effectively on notice to educate themselves about these precepts.

There are numerous principles which Noahides can and do extrapolate from the Torah as important for their observance. For example, the commandment to be fruitful and multiply was given to Noah, although rabbinic authorities agree this commandment was abrogated because it was not reiterated at Sinai. Nevertheless, one text concludes the following:

...the Children of Noah have the obligation to make the whole earth a dwelling place for mankind. This is minimally achieved by every couple giving birth to a male and a female child who are in turn capable of reproduction. Moreover, the couple that bears more children is credited with bringing more spiritual goodness into the world, assuming that these children are reared in an environment of morality by fulfilling the Seven Universal Laws. ${ }^{235}$

Noahides also have a duty at death to bury their dead in the earth to be decomposed therein:

This does not mean that the Children of Noah transgress one of the Seven Commandments by utilizing another process such as cremation or cryogenic preservation, but they will lack the atonement that burial in the earth accomplishes. ${ }^{236}$

\footnotetext{
${ }^{234}$ Bar-Ron, Guide for the Noahide, 81. See also Schwartz, Noahide Commandments, 1.

235 Ibid., 38.

${ }^{236}$ Ibid., 38 .
} 
Respect for parents is one injunction that some texts place on Noahides, which can be read derived from the story of Noah and his sons. ${ }^{237}$ Female modesty is also mentioned by one source. ${ }^{238}$ The prohibition of murder is also implicit in the story of Cain and Abel, although it is later commanded explicitly to Noah. ${ }^{239}$ According to the Talmud's elaboration, sexual immorality is punished by the Flood. ${ }^{240}$ In the case of Schechem (the Hivite prince who rapes Dinah), the citizens of the town fail to adjudicate the crime. The citizens of the are subsequently slain for failing to do justice in accordance to the seventh Noahide law (to establish courts of law). ${ }^{241}$ These parables provide new ethical precepts and reinforce precepts already present in the Noahide law.

There is, however, yet another level on which Noahide study is crucial. Noahidism is a relative infant on the world stage. A litany of legal, theological, and ritual disagreements still exist. Definitive answers are still difficult to come by. Study is a powerful tool in exploring the possibilities that Noahidism has to offer, or in other words, those who are armed with more knowledge are better able to shape Noahidism. Study at this point is not merely descriptive. There is still great liberty for interpretation and debate about how Noahidism should look, and study is an integral part of this dialectical process.

\footnotetext{
237 Cowen, Universal Ethics, 200.

See Gen. 9:18-29 for the story of Noah and his sons.

238 Bar-Ron, Guide for the Noahide, 92.

239 See Gen. 4 for the story of Cain and Abel.

${ }^{240}$ Novak, Natural Law in Judaism, 37.

${ }^{241}$ See Gen. 34 for the story of Schechem.
} 


\section{Prayer as Ritual}

I mentioned prayer in the previous section as a way of exercising repentance, but it is worth noting that prayer is advocated in the primary literature in its own right:

When a Noahide prays he certainly obtains reward as we learn from the Prophet Isaiah, 'My abode shall be declared a house of prayer unto all the nations of the world' (Isa. 56:7)...And King David wrote, 'Praise the Lord, all nations, extol Him all the peoples' (Ps. 117:1). This verse from Psalms refers specifically to the prayers of the Children of Noah. ${ }^{242}$

Cowen points out that while prayer is not required nor set in a specific structure, it is ideal for a person to pray daily and to even bless their food. ${ }^{243}$ Bar-Ron goes even further and says that the Psalms of David are allowed, and that even praying from an Orthodox siddur (prayer book) in all of its details can be taken on. ${ }^{244}$ Authorities have generally disagreed on this point because Maimonides limits what information Noahides can learn from the Torah. It would make sense then that the Siddur, replete with Torah knowledge that does not pertain to the Noahide, would also be off limits to the Noahide.

Some rabbis have shared this sentiment and have responded by drafting Noahide siddurs. They contain prayers for waking and sleeping, morning and evening services, an Aleinu prayer, blessings for foods and for meals, mourning, wedding services, travel, and

\footnotetext{
${ }^{242}$ Clorfene and Rogalsky, Introduction to the Noahide Laws, Ch 16.

${ }^{243}$ Cowen, Universal Ethics, 203-204.

${ }^{244}$ Bar-Ron, Guide for the Noahide, 162.
} 
the sabbath. ${ }^{245}$ Although not required, using a standardized set of prayers, even if a few different versions exist, helps create a focal point around which Noahides can exercise their spirituality in a way that is predetermined and useful in a communal setting. It also creates a type of legitimacy and security. Noahides may feel their personal prayers and petitions are not fitting or done in a way acceptable by Jewish standards. A prayer book eliminates this insecurity and creates consistency. Investment in the creation of Noahide siddurs is also sure to pay dividends because prayer is at this time an integral part of Noahide ritual or custom. Of 196 respondents, 139 report that they pray at least once a day $\left(71 \%\right.$ of respondents). ${ }^{246}$

The topic of prayer may also spark the curiosity of knowledgeable readers who are aware of Jewish meditation. They may wonder whether Jewish meditation has a place in the life of the Noahide. As fitting as this segue may be, I prefer to leave the topic of meditation for my discussion on the Kabbalah.

\section{Other Philosophical Innovations}

Despite differences of opinion throughout the literature regarding the breadth of Noahide ritual, there is generally a consensus that Noahides should go beyond the letter of the law and reinterpret the negative laws into positive ones. This reinterpretation yields

\footnotetext{
245 Emmanuel Villegas, Michael Schulman, and Chaim Reisner, eds. Noahide Seventh Day Prayers: Suggested Prayers for Noahide Community Services and Personal Worship (Davao City: Qelihat Chasidi Ha-Umot, 2013).

Also see Moshe Weiner and J. Immanuel Schochet, Prayers, Blessings, Principles of Faith, and Divine Service for Noahides (Ask Noah International, 2014). Also see "Daily Prayers," Service From the Heart: Renewing the Ancient Path of Biblical Prayer and Service, edited by Michael Katz, Yechiel Sitzman, Pam Rogers, Larry Rogers, and Nancy 100 (Rose, OK: OKBNS Press, n.d. PDF e-book. 2007).

246 Noahide Individuals Survey, Question 22.
} 
positive behaviors and actions which have the force of ritual or, at the very least, take the place of formalized, communal ritual. There exist legal arguments, as we saw in the chapter on law, for the positive reinterpretation of the Noahide code, but from a behavioral standpoint, authors have presented other arguments. Cowen, for example, argues that a positive understanding of the Noahide laws and the behaviors and actions implied by this understanding leads to "a refinement of character and conduct, beyond the basic Noahide laws. ${ }^{247}$ Dallen gives us a similar opinion, this time using the concept of virtue. Cowen's work is based very much on a particular psychological framework. Dallen, on the other hand, does not have a clear foundation. He mentions virtue, but I cannot be certain he is invoking virtue ethics in the Aristotelean sense. Such a philosophical commitment is not explicit and I have no good reason to pin down Dallen's commitments for him. He does make clear that "No one is virtuous unless he goes so far as to do the very opposite of whatever the Noahide laws forbid. A man cannot fully satisfy the Noahide law against larceny, for instance, unless he gives charity; the Noahide law against profaning God's Name unless he acts to sanctify the Name; the Noahide law against murder unless he acts to save the life of the person in danger."248 He goes on saying "A person cannot be called truly righteous unless he does the opposite of what the Universal Law forbids." ${ }^{249}$ Both Cowen and Dallen attribute a benefit to acting positively,

\footnotetext{
${ }^{247}$ Cowen, Universal Ethics, 208.

248 Dallen, The Rainbow Covenant, 66.

${ }^{249}$ Ibid., 141.
} 
but it is Dallen who seems to ascribe some kind of categorical difference between following the laws in their negative form as opposed to their positive reconstruction.

I may, of course, be reading Dallen's work too closely. I may be seeing something he did not intend. But his choice of the word "virtue" has a clear rhetorical motive. Virtue is something to be achieved, to be aimed for; it marks a difference in kind from someone who does not act positively and merely sits and does nothing, to use the Talmudix characterization of the laws. We can contrast this with Cowen's refinement of one's character, which reads more like a difference in degree.

Dallen's notion of positive action is also in some cases about justice and not simply a way to achieve the highest form of moral purity. When talking about the obligation of charity, he argues that charity is not a matter of "pity, kindness, or mere sentiment," but rather it is a matter of justice. Charity is an encumbrance on the right to own property, all of which essentially belongs to the Creator. ${ }^{250}$ There is a contradiction in Dallen's argument. Simply put, if the laws in their original, negative iteration form the baseline for ethical behavior, then we should assume that anyone who observes the negative commandments is within the bounds of justice. How then could Dallen claim that positive action, like giving charity, is the just thing to do. Are not the negative laws the baseline for justice? Are just behavior and ethical behavior somehow different? If giving charity is the baseline for justice, then the positive iterations of the laws become the new standard. If the positive iterations are the standard of justice, then what becomes

${ }^{250}$ Ibid., 140. 
of the negative iterations? Should they be discarded and replaced? And if so, what should we make of this divergence from rabbinic tradition?

We can also put the contradiction in another way: if the Noahide laws in their original, negative iteration form the baseline for ethical behavior and spiritual salvation, why would acting positively bestow virtue upon us? Do people without virtue make it into heaven? Those who follow the Noahide laws are said to be the righteous among the nations. Does virtue then differ from righteousness? I do not mean to be facetious about the matter, nor am I digging for discord. My intention is to point out that some of these philosophical innovations used to promote and in some cases require positive action have issues to work out.

Going back to Cowen for a moment, he couches his argument in different terms. He refers to the "positive expression" of Noahide law. ${ }^{251}$ He sees the human faculty of reason as "the Divinely taught guide to the harmonious habitation of the world." Human reason contains within it a tendency to refinement or progress towards harmony. There are several ways to achieve this refinement, first by transcending the purely negative observation of Noahide law to observe the semi-positive interpretation of the Law. After, one should adopt some of the 613 laws where appropriate and fortify the Noahide law through legal sanctions in one's community. ${ }^{252}$ The adoption of any of these measures cannot conflict with Noahide law itself. ${ }^{253}$

\footnotetext{
${ }^{251}$ Cowen, Universal Ethics, 76.

252 Ibid., 158-9.

${ }^{253}$ Ibid., 164.
} 
For Cowen, charity is also an obligation and not merely a "positive expression" of the prohibition of theft. He believes such obligations help ensure humans will transcend their self-interest and achieve a psychological shift in which crimes like theft will become unthinkable. ${ }^{254}$ I think this self-transcendence or psychological shift into a kind of moral intuition is what Cowen means by "refinement" and I find no issues with his general argument except for the fact that positive actions should not be characterized as Divinely imposed obligations. There is no issue with setting a fence around the Torah, as the rabbinic saying goes. That is to say, there is no issue with legislating positive action in order to keep humans from violating the negative laws, but it should be clear these obligations are man-made and not Divine.

I mention these arguments because they diverge from the typical method of argumentation which is Scriptural proof-texting. There is no shortage of proof texts in the primary Noahide literature, but these arguments put forth by Dallen and Cowen are conceptual innovations which help to open Noahides to new possibilities when it comes to ritual and positive behavior that enriches their religious lives.

\section{Kabbalah and Ritual}

Lastly I would like to examine Kabbalah and meditation as sources for Noahide ritual. A systematic skeptic should be easily roused when the idea of Noahide mysticism is brought to mind. Indeed, traditional Jewish mysticism envisions its spiritual practices exclusively for Jews. Gentiles are missing the neshamah, known as the third and highest

${ }^{254}$ Ibid., 76-7. 
part of the human soul. It is doubtful a gentile would be able to share in the Jewish mystical journey without the spiritual abilities associated with the neshamah. How then, can we talk of a Noahide mysticism akin to Jewish mysticism?

The issue is further complicated when we take into account how dependent contemporary Noahidism is on the Maimonidean codification of the halakhah. As already mentioned, Maimonides concluded in his Mishneh Torah that the non-Jew is prohibited from studying any part of the Torah which is not relevant to the practice of the Noahide laws. ${ }^{255}$ With very few exceptions, this point is generally agreed upon in the contemporary Noahide literature and presents a possible barrier to Noahide mysticism. Jewish mystical works, and especially Kabbalistic literature, lauded the depth of the Torah. In fact, the Torah is the primary vehicle for mystical contemplation, due to its potential to be interpreted infinitely many times at varying levels of literalness or abstraction, each interpretation more profound than the last. Yet the Noahide, without access to the entire Torah, is presumably incapable of exploring its spiritual depths. Given the centrality of the Torah in the Jewish mystical experience, Maimonides' restriction leaves the Noahide without a point to jump off from. Furthermore, without sufficient training in the Torah, other Jewish mystical texts are sure to be incomprehensible to even the most devout son of Noah.

We should also recall the fact that Noahides are allowed to observe some of the Sinaitic commandments only for their practical benefit, meaning they should remain

${ }^{255}$ Bar-Ron, Guide for the Noahide, 54-7. 
unconcerned with spiritual significance of the commandments. This is problematic because proper observance of the Mosaic commandments is seen by many as a prerequisite for the aspiring Jewish mystic. Most importantly, however, we should remember that many mystical schools see the performance of the commandments as moments through which to experience the shekhinah, the Divine presence, directly. The Noahide loses out on these mystical opportunities due to their lack of a ritual tradition. But even in cases where Noahides can perform Siniatic rituals, any potential for mystical experience is then effectively stamped out because the Noahide must turn their intention to the practical, mundane consequences of any ritual performance. A Noahide's intention cannot be fixed on the spiritual significance and benefits of a ritual.

Some texts do advise Noahides to stay away from Jewish mysticism. One author warns that the Kabbalah is far too complex for Noahides who have little understanding of the Torah's depths. ${ }^{256}$ Yet on the other hand, an entire text has been published exclusively regarding the mystical aspects of Noahide law. This appears to be contradictory, but actually can be explained by Noahide sectarianism. The text cited below is written by Rabbi Michael Bar-Ron, a Yemenite Jew who is committed to the Maimonidean conception of Jewish law. In his view, all rabbinic decisions after Maimonides' codification of the Mishneh Torah are invalid. This could explain the Rabbi's reluctance to promote Jewish mysticism. Maimonides was strongly opposed to the Jewish mystical schools. He favored Western rationalism and sought to explain the Torah in light of

256 Bar-Ron, Guide for the Noahide, 54-5. 
Aristotelian philosophy. This anti-mystical inclination is presumably present in the Rabbi's writing on Noahide law. The text on Noahide mysticism, however, was written by Rabbi Yitzchak Ginsburgh, a Chabad rabbi. The enthusiasm for Jewish mysticism in Chabad ideology and practice is undeniable, and it is perhaps this inclination which makes a text on mysticism for Noahides a worthy endeavor.

Some sources developed by Chabad rabbis have attempted to infuse the Noahides laws with a mystical dimension. Rabbi Cohen argues that Noahides, like Jews, are capable of retrieving the divine sparks left behind during the fracturing of the universe (described by the Lurianic account of creation). For this reason, the Noahide should act positively and not simply avoid sin, as it gives him a greater chance of elevating the isolated sparks. Charity, saving the life of another, blessing one's food, prayer, meditation, and other pious behaviors correlated with the Noahide laws should be the priority of the Noahide. As the Noahide performs more pious behaviors, more sparks are harnessed and the coming of the messiah is hastened. ${ }^{257}$ Rabbi Cohen's treatment of the Noahide laws is not explicitly mystical, that is, he does not describe the Lurianic/ kabbalistic significance of the Noahide laws in kabbalistic terms - his rhetoric is not mystical. Nevertheless, it is clear that his attempt to deepen the meaning of the Noahide laws is inspired by Jewish mysticism.

257 Cohen, Divine Image. 
It is in Rabbi Ginsburgh's work that we find an explicitly kabbalistic treatment of the Noahide laws. ${ }^{258}$ His work is rather intricate, attempting to develop multiple correlations between the seven laws and other concepts in Jewish ideology and mysticism. For example, he takes Maimonides' 13 articles of faith and demonstrates that they can be capitulated into seven. He then claims the seven Noahide laws are individually correlated to the seven articles of faith. This, he concludes, shows that the basis of the Noahide laws is faith in the Jewish god as opposed to rational, secular observance. ${ }^{259}$

This is a particularly interesting task Rabbi Ginsburgh has taken on, given that Noahide literature has unanimously agreed on Maimonides' dictum: a Noahide must accept Jewish revelation in order to merit the World to Come. Still, Rabbi Ginsburgh strives to show how faith in the Jewish god is a vital aspect of proper observance, despite the insistence that Noahidism is not a religion, as we explored in the previous chapter. And like many of the other Noahide texts, Rabbi Ginsburgh's work also makes similar exhortations for Noahides to pray, otherwise they fail to gather the divine sparks in the world. They should bless their food in order to access its spiritual power. He also strives to evoke the mystical aspects of significant life events, such as marriage. But perhaps more interesting is his technical usage of kabbalistic concepts. At the early stages of his work, he explains the soul structure of the non-Jew, explicitly stating that the non-

\footnotetext{
258 Yitshak Ginzburg and Moshe Genuth, Kabbalah and Meditation for the Nations (GalEinai Publication Society, 2007).

${ }^{259}$ Ibid., $22-8$.
} 
Jew lacks a neshamah. He goes on to argue that the non-Jew is therefore only capable of accessing the lower seven sefirot in a limited way. Various other correlations are made between the laws of Noah and the lower seven sefirot, at times even employing gematria to make the point stick. The prohibition against murder is related to gevurah, or might. Hesed, or loving-kindness, corresponds to the prohibition against adultery. Malkhut, or kingdom, corresponds to the requirement to establish a legal system. ${ }^{260}$ These correlations should appear fairly obvious, but Rabbi Ginsburgh's treatment is extensive, going so far as to correlate the sefirot and Noahide laws with the seven colors of the rainbow.

Perhaps more important for the Noahide, however, is Rabbi Ginsburgh's psychological treatment of the Noahide laws and the sefirot. This phase of his work is rather clever and understandably appeals to the Noahide starved of religious expression. He begins by arguing that each sefirah contains a specific spiritual power. Malkhut, for example, contains the power of humility; tiferet the power of mercy, so on and so forth. ${ }^{261}$ Because each sefirah is also correlated to a particular Noahide law, the positive performance of a Noahide law (as mentioned, the giving of charity in relation to the prohibition of theft) enhances that spiritual and psychological quality of an observant individual. Thus, one who gives charity will become more merciful; giving charity is the positive of the prohibition against theft, and this law is related to tiferet, which is related to mercy. This psycho-spiritual exploration undoubtedly provides a much needed layer of

\footnotetext{
260 Ibid., 77.

${ }^{261}$ Ibid., 100.
} 
depth to the Noahide laws. And much like the demand for Noahide siddurs, there is also some indication that Noahides are looking to the Kabbalah for spiritual enrichment. 77 of 200 respondents report they are currently studying the Kabbalah (38\% of respondents), whereas another 32 respondents (16\%) are interested in studying. Only 43 respondents $(22 \%)$ claim they are uninterested in such studies. ${ }^{262}$

In closing this chapter, we can look alternatively at secondary texts regarding Jewish mysticism and meditation. Not many secondary sources on Jewish mysticism treat the issue of the non-Jew in Jewish mysticism. Aryeh Kaplan's work on meditation does, however, suggest that the non-Jew can participate in meditative practices and prayer. His practical guide entitled Jewish Meditation is certainly written for a Jewish audience, yet he does not hesitate to make connections between Jewish and non-Jewish meditative practices. ${ }^{263}$ And despite its presentation for Jewish readers, Kaplan does not ask wouldbe meditators to be steeped in Orthodox Jewish ritual practice or theology. There seems then to be a space for the non-Jew to pick up Jewish meditation, but this is not advocated explicitly. Perhaps Kaplan does not do so because such a possibility has not crossed his mind, or maybe he is simply unable to find a justification for non-Jewish participation in Jewish meditation. Jewish mysticism is complex and tied to the particularities of the Jewish faith. This would be clear to the non-Jew who takes a deeper look. A non-Jewish reader who comes across another of Kaplan's texts, like Meditation and Kabbalah, might

\footnotetext{
${ }^{262}$ Noahides Individuals Survey, Question 20.

263 Aryeh Kaplan, Jewish meditation: A practical guide (New York: Schocken Books Incorporated, 1985).
} 
be intimidated by the intricate permutations and gematric calculations of God's divine names; they might then decide Jewish meditation is far beyond their mettle. ${ }^{264}$

Texts like Kaplan's do not provide much guidance for non-Jews interested in Jewish mysticism or meditation. Serious scholarship has yet to be done on the intersection of these two worlds, but the Noahide movement is wasting no time in wholeheartedly adopting Jewish mysticism as a way to enrich the spiritual experiences of Noahides. Despite clear impediments to the development of Noahide ritual, Jewish mysticism seems to provide a creative outlet and impulse for the adoption of other behaviors which can serve as a medium for religious expression.

264 Aryeh Kaplan, Meditation and Kabbalah (San Francisco: S. Weiser, 1985). 


\section{CHAPTER 5}

\section{IDENTITY AND CONVERSION}

There is good autobiographical and survey data to suggest that Noahides tend to be converts and that the journey from Gentile to Noahide can be a difficult one. A majority of Noahides, as many perhaps as $86 \%$, previously identified as Christians. ${ }^{265}$ Disavowing oneself of Christianity is difficult to varying degrees based not only on one's conviction that Christian dogma is true, but also on one's socio-cultural environment. Davis' account of his split from Christianity was unsurprisingly troublesome because he was the minister of a notable Baptist congregation in the core of the American Bible Belt. As a consequence, he received death threats, endured broken friendships, and was excommunicated by colleagues. Others may not have experienced similar tribulations due to their own environmental circumstances. Yet given the rather global scope and technological inclination of most contemporary Noahide communties, it is not surprising that even individuals like Rabbi Bar-Ron, who lives in Israel, has received hate mail from right wing Christian groups. ${ }^{266}$

In general, Noahides do find it difficult being publicly open about their identity in some part due to the obscurity of their religion. It may come off as rather cultish or fanciful. What is more, explaining Noahidism is a challenging endeavor. Is it a part of Judaism, or not? What kind of rituals do Noahides have? As if describing Noahidism is not difficult enough, it is complicated by the average person's lack of knowledge about

\footnotetext{
265 Noahide Individuals Survey, Question 11.

${ }^{266}$ Bar-Ron, Guide for the Noahide, 150.
} 
Judaism. The idea of non-Jews believing in the Jewish God is rather confusing. It is at odds with the common misunderstanding that the Jews are the "chosen people" and that Judaism is consequently exclusive and closed off to anyone who is not a bona fide Jew. The survey data speaks to these difficulties. Respondents have testified how Noahidism comes off somewhat cultish or confusing to non-practitioners. Around $30 \%$ of respondents claim that Noahidism is received indifferently by immediate family, extended family, friends, and strangers. More respondents feel their beliefs are more poorly received by family members than by strangers. ${ }^{267}$

These impediments often make it difficult for prospective practitioners to make the leap into a strong identification with Noahidism, or they at least make continuous identification burdensome. As if this were not trying enough, the religion itself unintentionally presents other obstacles to conversion. I have mentioned before how Noahide ritual (or the lack thereof) becomes problematic in this regard. $86 \%$ of Noahides are converts from Christianity, a religious tradition with a many rituals performed in and out of sacred spaces. Many of these rituals have also become secularized or popularized in such a way that even non-religious spaces are used for celebrating these holidays. We can identify not only the sacraments of baptism, communion, and marriage as examples, but the more popular ones as well like Christmas and Easter, which give individuals a strong sense of community with their family and society at large. Regardless of how atheistic, agnostic, or secular one's community might be, the Christmas holiday is

${ }^{267}$ Noahide Individuals Survey, Question 25. 
practically inescapable in the United States due to its secularization and commercialization.

These more popular rituals like Christmas and Easter have proven incredibly difficult for Noahides to let go of, and this is only exacerbated by the poverty of Noahide ritual. Had Noahidism its own set of rituals, we could speculate they would replace the Christian rites once before practiced by many Noahides. What this means is that the psychological shift into Noahidism may be problematic, of course not in a pathological way, but insofar as it is difficult for newly converted Noahides to maintain their motivation and affinity for their newfound religion without a set of behaviors that reinforces core beliefs, habituates individuals towards a new lifestyle, and provides a distraction from previous lifestyles.

One way to deal with a new religious identification symbolically and psychologically is to undergo conversion. Whereas Orthodox Jewish groups tend to administer a rigorous conversion process replete with ritual and often lasting as long as a year, Noahidism has no conversion process whatsoever. And if the rabbis are correct about the poverty of Noahide ritual, then no such conversion process can or should be implemented. This presents an issue for many Noahides who find it difficult to separate themselves from their Christian background. Without a conversion process, there is no guarantee of a clean break between one's Christian past and one's Noahide future. It is unfortunate we cannot discuss Noahide conversion in a formal sense, although we can speak briefly about the informal details concerning the shift into 
Noahide identity. We can also discuss how the possibility of conversion to Orthodox Judaism affects Noahide identity.

\section{Identifying as a Noahide}

Without a formal conversion process in place, identification as a Noahide is a psychological event and not a metaphysical or symbolic one. Some Noahides have made formal pledges of allegiance to the Noahide laws, the Hebrew Scriptures, and to particular rabbinical courts, yet there is no halakhic precedence for such a custom and, if we are to take current doctrine seriously, there is every reason to believe that establishing a formal pledge of allegiance would violate the prohibition on the creation of rituals for Noahides. ${ }^{268}$ A pledge would provide a moment in which a significant psychological shift could occur; it would be a real, tangible marker for a shift into Noahide identity, but the custom is not practiced enough to merit investigation. It is not a considerable part of contemporary Noahide life.

While true that a formal process for Noahide conversion does not exist, this does not imply that the shift into Noahide identity does not possess qualities of its own. Noahide conversion differs greatly in kind from Jewish conversion. Most conversion processes are marked by some sort of transformation. Orthodox conversion is no

\footnotetext{
268 Ezra HaLevi, "Sanhedrin Recognizes Council to Teach Humanity 'Laws of Noah' - A Group of NonJewish Delegates Have Come to Jerusalem to Pledge Their Loyalty to the Laws of Noah," Arutz Sheva Israel National News, October 1, 2006, Accessed October 3, 2016, http://www.israelnationalnews.com/ News/News.aspx/96347.

Also see IsraelNN Staff, "Four New Noahides Welcomed into the Fold in Jerusalem - Four Gentiles Declared Their Acceptance of the Seven Laws of Noah," Arutz Sheva Israel National News, May 10, 2009, Accessed October 3, 2016, http://www.israelnationalnews.com/News/News.aspx/133714.

Also see WeJew.com, Israel and Jewish Videos, Accepting The Laws Of Noah, October 5, 2009, Accessed October 03, 2016, http://wejew.com/media/6330/Accepting the Laws_of_Noah/.
} 
different. It is believed the convert's soul is fundamentally changed upon conversion. Some hold that a new part of the soul is awakened while others even go as far as claiming the convert receives a new, Jewish soul altogether — the gentile soul is shed. Noahide conversion, on the other hand, lacks any numinous quality. The Noahide convert might change in degree, that is, the Noahide might become more holy and righteous through piety and observance of the seven laws, but the Jewish convert changes in kind because his very soul is altered categorically.

Noahide conversion, to the extent it is practiced, does not therefore symbolize a transformation in a metaphysical sense. Without a formal conversion ritual, little can be said about the symbolism of one's passage into Noahidism. There is, however, a defining feature of Noahide conversion as it is practiced today, and it has to do more with the consequent power relations than with theology or metaphysics. In cases where Noahides interact with Orthodox Jews, identification is a process of exchange. ${ }^{269}$ By converting to Noahidism (or rather by identifying as a Noahide), one grants religious and cultural legitimacy to Orthodox Judaism from a demographic that has historically dismissed Jewish culture, which I doubt would irk any rabbi. Given the history of Jewish relations with the Western world, one could only imagine how happily rabbis would welcome such support from Gentiles. What the Noahide gets in return is access to the Jewish community and guidance from its leaders. Noahides are able to openly praise the Jewish

\footnotetext{
${ }^{269}$ See Michal Kravel-Tovi, "Bureaucratic gifts: Religious conversion, change, and exchange in Israel." American Ethnologist 41, no. 4 (2014): 714-727.

Kravel-Tovi highlights this exchange and describes how the state-sponsored Orthodox conversion processes are used to integrate immigrants are based on an exchange of power rather than the mere transformation of the convert.
} 
god in the presence of Jews without having to be a Jew themselves; Noahidism is in turn legitimized and given structure.

Still, this exchange model does not fit every case. For many practitioners who have no sustained interaction with Jewish or even Noahide groups, the exchange process is not really at play. These individuals, and they do exist, merely identify as Noahides, keep the seven laws as they understand them, and pray individually. Their practice requires no legitimization and their relative isolation and obscurity in society does little to legitimize Jewish communities.

So informal is Noahide conversion that it does not fit well in any of the other models I have examined. Without a formal procedure, we cannot categorize the structure or symbolism. Not even psychological models apply. For example, Loftland and Stark provide a model in which individuals adopt religious views in order to reinterpret reality and cope with trauma, life changes, and other types of malaise. ${ }^{270}$ Perhaps I am unable to apply this model due to my lack of ethnographic work with Noahides. Without a good portrait of the individuals within the various Noahide communities, it is impossible to tell if they come from circumstances or environments which make them willing participants in Noahidism's structure, socialization, and mythos. It is also generally difficult to see how Noahide identity, thought, ritual or socialization offer the kind of support needed to confront poor socio-cultural conditions or existential turning points; Noahide ritual can hardly be said to exist; Noahides do not tend to socialize intensely given the lack of

${ }^{270}$ Hunt, Alternative Religions, 101-102. 
physical community and a general insistence upon cultural plurality; Noahide thought, which is legalistic in nature, may provide some kind of structure to practitioners, but we have to remember the laws are rather broad and not geared towards self-help or the rigors of daily life. Hassidic thought might be more helpful to Noahides seeking to resolve conflicts in their lives, but not all Noahides are exposed to Hassidic thought.

Without multiplying examples much further, I would like to point out that even the role model theory does apply to Noahide conversion. This theory of conversion emphasizes the process of learning in order to attain access or identification as a practitioner. If the role model theory is applied to Noahidism, then practitioners would have to know a certain amount about the laws, a certain amount about Jewish theology, etc. in order to be considered a bona fide Noahide. This, however, is not the case at the moment. Identification as a Noahide seems to be rather lax and merely contingent upon acceptance of the seven laws and the truth of the Hebrew Scriptures, even if the individual is in the dark about their details.

It is, however, important to note that Noahides who interact more often with Orthodox communities also tend to read more texts related to Noahidism. ${ }^{271}$ This does not necessarily imply that a certain level learning is necessary for access to Orthodox communities, although it could. At the very least it does mean that learning is an integral part of Noahide relationships with those communities.

\footnotetext{
${ }^{271}$ Noahide Individuals Survey, cross tabulation of Questions 15 and 17.
} 
The last thing I would like to say about Noahide conversion regards evangelism or, to put it more clearly, the process by which Noahides seek new practitioners. Here again it is important to repeat the fact that a great number, arguably a majority, of Noahide practitioners were once Christians. Yet surprisingly there is no tendency among Noahides to evangelize. It may be that the Jewish reluctance to advertise their religion rubs off on Noahides. It could also be that the complexity of Noahidism and its odd connection to Judaism make it difficult to communicate, and therefore difficult to carry out cold-call evangelizing. Its also safe to speculate that a Noahide's socio-cultural environment can act as a hinderance to evangelism. A Noahide in the American Bible Belt may be less apt to share his or her knowledge than a Noahide in New York City. Some Noahide authors are aware of the social rigors involved with being a Noahide and address these issues. In Rabbi Bar-Ron's writing, for example, an FAQ section is devoted to advising Noahides how to talk to their families and friends about their beliefs, how to relate to idolaters among family and friends, and other communication issues one might confront in the course of daily life. There is even a section concerning how to approach customs like Christmas trees. ${ }^{272}$ But most importantly for this section, Rabbi Bar-Ron insists in his writing that Noahides should prioritize the establishment families and communities over evangelization. ${ }^{273} \mathrm{He}$ argues the Torah demonstrates the value of longevity and patience in this regard.

\footnotetext{
272 Bar-Ron, Guide for the Noahide, 137-40.

${ }^{273}$ Ibid., 87.
} 
Noahides may have a rough time in many regions of the United States, but 7,000 miles to the west in the Philippines, the opposite is true; entire Christian congregations often convert to Noahidism. It is reported that Noahide pastors are invited to share their beliefs at Sunday services and it usually isn't long before the crucifix is replaced with the star of David. I am not certain to what extent such reports are true. One can find a good number of pictures and videos of entire Noahide congregations in the Philippines, which is an interesting phenomena all on its own, but this does not confirm stories of mass conversion. If these reports are true, they would point to the great influence of sociocultural conditions on the proliferation and organization of Noahides and their communities.

Despite the impediments to Noahide conversion (or perhaps we should say to adopting Noahide identity), individuals become Noahides rather quickly, typically within the first five years after having learned of Noahidism. ${ }^{274}$ It would be nice to know whether the process of identification is accelerated by interaction with Orthodox, Noahide groups, or by geographic location, but unfortunately I cannot determine this from my survey data. More extensive ethnographic research or a more nuanced survey would be required to get a grip on the many variables involved in the transformation from Gentile to son/daughter of Noah.

\footnotetext{
${ }^{274}$ Noahide Individuals Survey, cross tabulation of Questions 6 and 7.
} 


\section{Identity and Conversion to Orthodox Judaism}

Also important to all involved is the leap from son/daughter of Noah to Jew. That is, what should we make of the possibility that a Noahide could become a Jew? Many rabbis and Noahides question whether Noahidism is a gateway to Orthodox conversion, or whether Noahidism is an end in itself. Others wonder if all Noahides will become Jews after the coming of the Messiah. A more imminent question, however, is whether Noahidism should be used as a litmus test to challenge the conviction of prospective Orthodox converts.

This thesis cannot provide theological or theoretical answers to these questions in depth. They are currently at the fringes of Noahide speculation and there is little consensus on possible resolutions. Most important to consider is how these questions and their solutions would affect contemporary Noahides. After some consideration, I am not sure that speculating about these questions would help clarify Noahide identity to any significant degree. Add then the fact that resolving these questions definitively would require a profound analysis of Jewish law, custom, and eschatology. The best I can do and most relevant to this thesis is to describe how this topic is approached by Noahides and Orthodox rabbis today.

The importance of Noahidism to the Jewish world view has been clearly established in various points throughout this thesis. Yet the functional value of Noahidism to contemporary Jews is unclear. I speculated before I began this research that Noahidism would or at least should appeal to Orthodox rabbis as a way to curb or challenge the 
conviction of prospective Orthodox converts. It is well known that rabbis have administered, as a custom, very rigorous conversion processes, a part of which is to dissuade converts before beginning on the path.

I attempted to contact various rabbis concerning this issue and even sought to have one rabbi conduct a survey among his prospective converts, but these efforts were unsuccessful. I have casually discussed the issue with rabbis and have been told that there is no concerted or conscious effort to use the Noahide laws as a part of the conversion process in the United States. A convert's conviction is measured in other ways. I also assume that, insofar as the rabbis are concerned, learning about the Noahide laws does not enrich the convert's understanding of Judaism, although one could imagine how the seven laws could be presented as a precursor to deeper study of the Talmud.

It is fairly safe to assume that Noahidism would be a powerful tool to test the resolve of a convert. I can hear it now: "Why do you want to be a Jew? You can live a perfectly holy life as a Noahide. No Passover cleaning, no Yom Kippur fasting, no kippot flying away in the wind right as you're running onto the train..." But this simply is not the way rabbis conduct their conversions.

Without sufficient data, I cannot speculate why this is the case. The data does indicate that a small number of Noahides attempt to convert to Orthodoxy. $21 \%$ of survey respondents tried before or after identifying as a Noahide, or are currently trying. Another $20 \%$ are interested in doing so, while $53 \%$ have never had or no longer have any interest 
in Orthodox conversion. ${ }^{275} \mathrm{I}$ have to admit my personal surprise at these numbers. I expected that Orthodox conversion would appeal to a good majority of Noahides, yet Orthodox conversion appears to be the exception to the general trend where individuals are interested primarily in life as a Noahide. Having said that, I have no reason to believe these statistics are at odds with other features of Noahide experience or doctrine. They seem to be perfectly believable and point to the fact that Noahidism is de facto not a gateway to Orthodox Judaism, although there are cases where Noahides have converted after having observed the seven laws for some time.

The data also supports a point made earlier regarding the place of Noahidism in the process of Orthodox conversion. Of 31 respondents who failed to become an Orthodox Jew, seven cited belief that Noahidism was sufficient for living a holy life. Only a few of these responses mentioned being instructed by a rabbi not to convert to Judaism, but to take up the path of a righteous Gentile instead. The remainder of these 31 respondents cite other common issues with Orthodox conversion: the process was too rigorous, their immediate family did not desire conversion, or there was no Orthodox community in geographic proximity to conduct a conversion. ${ }^{276}$ This goes to show that Noahidism is not utilized as a critical part of the Orthodox conversion process, whether to dissuade or educate prospective Jews.

This is not currently problematic for Orthodox Judaism. The turnover from Noahide to Jew is not a point of interest for Orthodox rabbis, although this could change

\footnotetext{
275 Noahide Individuals Survey, Question 8.

${ }^{276}$ Noahide Individuals Survey, Question 9.
} 
with time, particularly as the fervor for the Messianic age grows. One author acknowledges that "There are, however, differences of opinion as to whether the ultimate stage of humanity will comprise both Judaism and Noahism or that Noahism is only the penultimate level before the universalization of Torah Judaism."277 These differences of opinion are diverse and do reflect interesting ideas on how Noahidism is to be approached at the moment. Some outspoken Jews believe Noahidism should not be treated as a movement in its own right, but merely a stepping stone to Orthodox conversion. Within the Noahide world, however, the general disposition is clear. Regardless of whether or not Noahidism is an end in itself and a part of the Messianic world, it is to be taken seriously in the here and now. It is a mechanism for spurning the coming of the Messiah, for creating a world in which the presence of God may dwell.

\footnotetext{
277 Green, Universalism and/or Particularism, 4.
} 


\section{CHAPTER 6}

\section{IDENTITY AND SECTARIANISM}

The intimacy between Noahides and Orthodox Jews is also evidenced by the variety of Noahide sects that have developed in the last 20 years. In some ways, Noahide sectarianism often reflects Jewish sectarianism and at other times it deviates based on distinct factors. In this section, we will quickly highlight these features and leave them prepared for future investigation.

In the cases where Noahide sectarianism corresponds to Jewish sectarianism, this occurs mainly across the spectrum of Orthodox Jewish sects and not in relation to Conservative and Reform Judaism. The reasons for this are unclear at the moment, but I speculate it is because the Conservative and Reform movements are not incredibly interested in Noahidism as a living, breathing movement. Non-Orthodox thinkers, like Cohn-Sherbok, have touted the laws of Noah as a means to engage in constructive interfaith dialogue and inclusivist behavior among religions, but not as an ideological framework of an independent religious group. In short, as non-Orthodox Jews increasingly become religious inclusivists or pluralists, there is consequently less emphasis placed on having non-Jews perceive and accept Jewish religious truths in Jewish terms, which is in one way of defining Noahidism. Instead, pluralist or inclusivist non-Orthodox Jews notice the universal truths of all religions and are willing to share those truths with others regardless of their particular religious identity. 
There may be other reasons why non-Orthodox Jews are not be so invested in the development of the Noahide movement. As we have already discussed, one aspect of Noahidism is its role in the messianic narrative of the Jewish scriptures. Conservative and Reform Jews do not believe the Noahide movement is the fulfillment of a messianic prophecy because they have altogether abandoned the traditional eschatology.

Noahidism has also been described as the minimal standard of piety and virtue for non-Jews, as well as the minimal standard of comportment in a society where Jews and non-Jews live together. But here again, Conservative and Reform Jews have digressed from this thesis. These groups have already accepted secularism, meaning the observance of secular laws and values is the standard through which members of a community accept one another, whether in the United States, in Israel, or elsewhere. In short, Noahidism seems to be unimportant to non-Orthodox groups because these groups have already dismantled, reinvented, or shunned many of the Orthodox concepts which Noahidism serves to navigate or compliment. This is not to say Conservative or Reform groups would be unable to harbor and nurture Noahides, but certainly there are reasons why Noahides have gravitated towards Orthodox Judaism.

The first way we could explain this phenomenon is through a simple observation. More than $86 \%$ of the individuals who replied to my survey come from a Christian background. ${ }^{278}$ In their eyes, the Old Testament is already authoritative, but if we look into Hanke's and Davis' biographies, we see they yearned after a definitive, original

\footnotetext{
${ }^{278}$ Noahide Individuals Survey, Question 11.
} 
understanding of the text, uncorrupted by Christian (or any other) interpretation - this is where Orthodox Judaism comes in. Orthodox rabbis boast a long lineage of Torah study, analysis, and application which Reform and Conservative movements cannot; the latter movements are admittedly contemporary or modern interpretations of the original texts, which does not appeal to Noahides. What is more, the Orthodox rabbis also can boast ownership of the Talmud which, if they are correct about its history, ties them directly to the oldest understandings of Jewish law from the era of Jesus and before. Noahide literature constantly stresses the importance of the Oral Law and the Talmud in developing a comprehensive and authentic Jewish understanding of the Old Testament. Additionally, these sources are also presented, and accurately so, as incredibly complex such that the guidance of a learned Talmudist is essential in developing a coherent understanding of the Talmud. Not surprisingly, the ethos of the Orthodox rabbis as the gatekeeperrs of authentic Biblical knowledge must play a great role in the firm relationship between Noahidism and Orthodox Judaism.

We can also cite another statistic to legitimize this relationship. Of the people surveyed, more than $57 \%$ report that they learned about Noahidism through an Orthodox Jew or a Noahide. This pales in comparison to the $.02 \%$ that heard about Noahidism through other Jewish denominations. ${ }^{279}$ This shows that even if Reform and Conservative Jews are open to the Noahide movement, they are not particularly active in outreach or,

${ }^{279}$ Noahide Individuals Survey, Question 4A-4D. 
for reasons explained before, Noahides are not interested in the non-Orthodox understanding of Noahidism.

Although the relationship between Noahide and Orthodox Jewish groups is clear, it is difficult to name or delineate the various sects of Noahidism. It is unclear whether or not Noahides see themselves as divided by Jewish sectarianism. That is to say, do Noahides make distinctions between Chabad Noahides and Yemenite Noahides, or Sephardic Noahides and Karaite Noahides, etc.? Secondly, sectarianism has as much to do with behavior as it has to do with ideology. Noahides may disagree on the structure of Noahide law, but this does not necessarily make them members of different sects. Because I was not able to directly observe and analyze behavior among Noahides of different groups, it is difficult to draw up a clear taxonomy of Noahide sects, but it is by no means impossible to observe that sectarian division sof some kind do exist. ${ }^{280} \mathrm{We}$ can generally see Noahides identify or follow a specific rabbi or group of rabbis who themselves identify with a specific Orthodox Jewish sect. Again, this does not imply that Noahides must also identify so strongly with that sect, but it does show that Noahides do not all come in one shade.

Kaplan's historical account of the Noahide movement in its infancy demonstrates sectarian tension has played a role in the group. He notes the movement's first efforts to reach out to Jewish communities aimed at Chabad Lubavitcher, other American Orthodox rabbis, and eventually towards the Chief Rabbinate of Israel. This was opposed by

\footnotetext{
${ }^{280}$ It is unfortunate I did not think to survey this particular issue.
} 
elements of the early Noahide movement, like Rabbi Michael Katz, who suggested affiliations with the Heredi, Mizrachi, and Agudat Israel movements, based largely on political reasons rather than theological ones. ${ }^{281}$

There is undoubtedly a large number of Noahides who identify with the Chabad movement. While we cannot say Chabad is obsessed with promoting the Noahide laws, there is evidence to show the movement does see it as a priority, perhaps more than other Jewish groups. The relationship with Chabad and Noahidism may not have begun in earnest. Kaplan notes that in the 1990's, the Lubavitcher movement was reluctant to identify itself with the Noahide movement, to the point of not sending a representative to the first international convention, despite promises to do so. This leads Kaplan to conclude that Noahidism might serve as a strong ideological tool to motivate messianic expectation among Chabad Jews, and that it is not an actual priority for them. ${ }^{282}$

Since then, however, I think it is fair to say that Chabad rabbis have been most active in organizing the Noahide movement. Some of the most prominent Noahide texts and internet websites are created, sponsored, or funded by Chabad organizations and rabbis. ${ }^{283}$ Chabad has also been very public about its desire to see a world governed by the Noahide laws. Two Chabad-operated entities currently serve as United Nations

\footnotetext{
${ }^{281}$ Kaplan, Radical Religion, 105.

282 Kaplan, Radical Religion, 45.

${ }^{283}$ For example, the Divine Code, which is the first rigorous explication of Noahide law in Hebrew, and translated into English, was sponsored by asknoah.org, one of the leading Chabad sources for Noahidism.
} 
NGO's and strive to build awareness of the Noahide laws. ${ }^{284}$ I have found a picture from a parade in Crown Heights, NY, the epicenter of the American Hassidic movement, showing a float sporting a large papier maché leaning tower of Pisa, the bed of the float adorned with flags from various countries, and in the center a large papier maché globe. Flanking the globe are two mannequins who appear to be Gentiles holding up a banner which sits above the globe. The banner implores onlookers to "Observe the 7 Universal Laws."

The overwhelming support Noahidism receives from Chabad is no doubt a consequence of the emphasis which the last Rebbe placed on the observation of the Noahide laws in order to spurn the coming of the Messiah in our time. Other observers have noted this tendency as well. Ariel writes that

The sixth rebbe (master), Rebbe Joseph Isaac Schneersohn (1880-1950), interpreting the Holocaust as a sign that cosmic redemption was imminent, decided in the late 1940s to dispatch outreach agents to secular and liberal Jews. Both he and his successor, Menahem Mendel Schneerson (19021994), were inspired by a messianic understanding of divine economy and the unfolding of history. They believed that their group of Hasidic Jews should help prepare the way for the messianic age by promoting observance among Jews as well as encouraging non-Jews to follow elementary, universal, Noahide laws. ${ }^{285}$

Another Noahide text quotes the late Rebbe Menahem Schneerson at length, saying that the Noahide Laws is the only objective ethical system capable of guiding humanity towards goodness. The emphasis which Chabad leaders and rabbis have placed upon

\footnotetext{
${ }^{284}$ Rabbi Boaz Kali directs 7 for70, the name referring to the 7 universal laws to guide the 70 nations created by God at the dispersion of Babel. Rabbi Yakov Cohen operates the Institute of Noahide Code.

285 Yaakov Ariel, "Jews and New Religious Movements: An Introductory Essay," Nova Religio: The Journal of Alternative and Emergent Religions 15, no. 1 (2011): 13.
} 
Noahidism makes it undoubtedly the vanguard of Noahide-Jewish relations at the moment, and it shows the importance of Noahidism in the Chabad worldview. ${ }^{286}$ Chabad embraces the eschatology of the Hebrew scriptures in which Gentiles turn to the Jewish deity, and they go a step further by seeing the fulfillment of this eschatology as imminent, thus requiring them to encourage the observance of the seven laws. But Chabad philosophy in general is also a contributing factor to their enthusiasm for Noahidism. Hassidic Jews openly see the world, whether Jewish or Gentile, as replete with sparks of the Divine. As humans, our duty is to connect with these sparks and use them to make the mundane holy, to make every corner of this world an abode for God's presence. So the logic goes that if humans could corrupt the world before the Mosaic Law and the birth of the Jewish nation, then they were also able to enhance the world despite the fact that Jewish ritual and law had not yet been born. The means of doing so were the Noahide Laws. Every human is capable of developing a connection with God, and this attitude is certainly in line with Hassidism's demeanor that every act can be undertaken to fulfill the Divine purpose.

There is also, as we have seen, a Yemenite Noahide sect, led by Rabbi Bar-Ron. The distinguishing feature of this sect is the idea that the Maimonidean codification of Jewish law is the last authoritative codification, such that Noahide law must also be based on Maimonides' understanding. The argument, according to Rabbi Bar-Ron, is that the Sanhedrin is the only institution that can legislate Jewish law, so any Jewish legal

\footnotetext{
286 Weiner et al., Go(o)d for You, 3.
} 
innovations after the destruction of the Sanhedrin are not binding. Maimonides' codification of Jewish law, so the Yemenites believe, is a compendium of the legal decisions last made by the Sanhedrin before its destruction. ${ }^{287}$ In this sense the Rabbi and his followers seem to be unique in the Noahide world. Reading other Noahide texts, whether penned by rabbis or not, makes it clear the legitimacy of contemporary rabbinic innovation is generally respected in the Noahide communities. ${ }^{288}$

Rabbi Bar-Ron teaches his understanding of Noahidism through a virtual yeshiva called Beth Midrash Ohel Moshe, wherein he applies the Yemenite (Maimonidean) reading of Jewish law. I have not been able to account the details of the Rabbi's success, but to put it in some context, every week I receive a lengthy email which informs recipients of various bits of information: relevant information about upcoming Jewish holidays, a Jewish song of the week, a kind of This Week in Jewish History bulletin, questions to ponder when reading the upcoming Torah portion, and times for the coming week's online classes. It is this last detail which is especially indicative of his success.

Rabbi Bar-Ron teaches to Noahides in the Phillipines, Israel, Norway, the Netherlands, Germany, the United Kingdom, Chile, the United States, Grenada, Colombia, and various other countries. The frequency and variety of his emails indicates sustained interest in his work, and the geographic breadth of his customers reveals how the message of Noahidism appeals to individuals across diverse cultures. Most important to this chapter, however, is the point that the Noahides who are learning with Rabbi Bar-

\footnotetext{
${ }^{287}$ Bar-Ron, Guide for the Noahide, iii-iv.

${ }^{288}$ For an example, see Dallen, The Rainbow Covenant, 320.
} 
Ron could be identifying strongly with Yemenite Judaism, its ideology, and its customs, such that Noahides would presumably perceive differences between themselves and Noahides outside of their group.

Yet another group, which I have not been able to track down successfully, is a Karaite Noahide sect. I have seen them mentioned on the internet, but I have not found definitive evidence of their existence and how they apply Karaite ideology to the Laws of Noah.

These are merely some examples of Noahide sects that follow the Orthodox Jewish typology. A detailed analysis of this aspect of Noahide identity could very well be the focus of an entire research project. Other Noahide movements do not follow the typology of Jewish sects, but actually develop upon nuanced understandings of Noahide law which do not directly correspond to a particular brand of Jewish ideology. One example of this is the Ger movement already mentioned in the chapter on ritual. This particular sect has developed as a response to the poverty of Noahide ritual. In order to do this, they have undertaken a unique interpretation of Noahide law which is not contingent upon the ideological narratives of a particular Orthodox Jewish sect, but instead based on the interpretation of certain Hebrew words. These particular translations, if correct, would privilege Noahides to observe a good number of Jewish rituals without restriction or alteration.

Other Noahide groups independent of Jewish sectarianism tend to form on the internet, but I think it is difficult to regard these groups as independent sects, for a variety 
of reasons. First of all, it is not clear the members of these online communities adopt a specific ideology or form of practice by means of their online membership. This is due perhaps to a second factor, the tendency for individuals to hold membership in various online communities. It seems that when practitioners are not aligned with a Jewish Orthodox sect, they tend to associate with more than one online community. There may be many reasons for this, but I think the primary one is that different groups offer different services. For example, some Noahide groups are outspokenly anti-Christian, and a great deal of their rhetoric is aimed at denouncing the validity of Christianity in favor of the Noahide laws. More than $70 \%$ of the posts on one website, for example, concern the denunciation of Christianity. These kinds of groups are helpful to Noahides struggling with their attachment to their Christian identity. Some practitioners and leaders in the Noahide movement avoid being so confrontational and prefer to laud the attributes of Noahide law instead. Other groups are more useful in addressing the concerns of Noahides positively. They establish online Noahide dating groups or online Torah study groups.

Lastly, categorizing practitioners who are not aligned with Orthodox Jewish sects or rabbinic leadership may also prove difficult because many Noahides tend to see themselves as being beyond categorization. They not only oppose sectarian categorization, but even being called a Noahide at all. This is a sentiment I have encountered repeatedly in my survey. The justifications for this sentiment vary, but generally they come in two kinds. Some refuse to be categorized as a Noahide because 
they claim the term does not encompass the essence of their role in the world; they prefer other categorizations, but are skeptical of just about any barring the Jewish terms ger tzedek and ger toshav. The issue with these of course is that they sound too foreign for outsiders. Others refuse categorization because they believe, as already mentioned, that Noahidism is not a religion. There is no way to refer to someone as a Noahide because this term attempts to describe a member of religious group. The problem in their eyes is that no such religion named 'Noahidism' actually exists.

As far as I know, this is a fairly unique phenomenon in the history of religions, particularly in the contemporary history of alternative religions. Most members of alternative religions tend to seek a strong sense identification with their group or creed, but many Noahides differ in this regard. It is not impossible to create a typology for practitioners who reject identification; I do not believe they are immune to some form of organization, even if it is imposed by an outside observer. Yet I do think it would be difficult because these Noahides generally seem to be less willing to gravitate to a particular group. They may be members of various groups, affiliating themselves only loosely. Or they may be satisfied with a minimal ideological and ritual commitment.

This phenomenon, however, is not the norm. The tendency for Noahide groups to organize around the leadership of a rabbi or group of rabbis is the general rule, and it is not surprising given the ethos of Orthodox rabbis and the way in which they control access to what Noahides believe is the authentic understanding of the Hebrew Scriptures and Jewish ritual. In keeping with this trend, I have been unable to find groups of 
Noahides which have organized independent of rabbinic leadership. This is also understandable considering that Noahidism is seen as an ancient religion which is blossoming anew; the duty of Noahides is not to create a new religion, rather to rediscover and reanimate an old one. Here again, the Orthodox rabbis are considered the gatekeepers to this ancient religious tradition. On the other hand, it is odd that Noahides have not organized independently. As I have already noted, contemporary Noahide literature is replete with calls for Noahides to mold their own version of Noahidism based on each individual's cultural values. Noahidism is supposed to reflect the divinely imposed diversity of the human race rather than create a group of people culturally and ethnically distinct among the nations of the world; that role is reserved for the Jewish people.

The lack of independent groups may be due to the fact that Noahide communities tend to be small. Or in other words, Noahides find it difficult to associate with other Noahides in their immediate geographical location because there are so few Noahides in the world. This is evidenced anecdotally and statistically. $24 \%$ of survey respondents say they interact in Noahide communities which are not internet based, compared to $69 \%$ who say their interaction is online. ${ }^{289}$ Without the guidance or encouragement of other Noahides, an individual has to go to the next best thing, which is a Jewish community. As a result, Noahides must often seek association with other Noahides through rabbis, synagogues, or other forms of Jewish community. My survey indicates that $73 \%$ of

\footnotetext{
${ }^{289}$ Noahide Individuals Survey, Question 18. It is important to note there is overlap between these two groups, that is, respondents may belong to internet based and non-internet based Noahide communities. Nevertheless, this statistic shows the importance of internet-based interaction.
} 
respondents have attempted, will attempt, or already do participate with a Jewish community, in comparison to the $10 \%$ that have no interest in doing so. ${ }^{290}$ Perhaps once Noahides become more numerous and the movement matures, then we will see groups form independent of rabbinic leadership. Then Noahide communities would be large enough to have a hierarchy or group of leaders who have a sufficient understanding of Noahide ideology and ritual to operate independent of rabbinic instruction. Additionally, a large Noahide community would make it possible for individuals to encourage each other and interact with one another without having to meet through a Jewish institution. Or perhaps none of this may come to fruition, regardless of the size or maturity of Noahide communities. The rabbinic ethos may still be a key aspect of Noahide identification and organization, such that Noahides will see rabbinic guidance as a sign of a community's legitimacy. It is too early to tell and I do not feel I have the data to speculate. What is clear at the moment is that Noahides do value rabbinic guidance and association because of the rabbinic ethos and because the institutions established by rabbis tend to facilitate interaction among Noahides.

Other factors could be analyzed to understand the makeup of Noahide practitioners, but it should be noted that few factors can describe them in a general sense. As Kaplan has noted in his analysis of small religious groups and right-wing political ideology in the United States, Noahide practitioners tend to defy secular political categorization; they cannot be seen as primarily right-wing or left-wing. ${ }^{291}$

\footnotetext{
${ }^{290}$ Noahide Individuals Survey, Question 14.

${ }^{291}$ Kaplan, Radical Religion, xiv.
} 
Yet just how strongly Orthodox Jewish sectarianism factors into Noahide identity is unclear. It may be more important among some groups of Noahides, and less important among others. I should mention I have not encountered any Noahide literature which talks down a sect of Orthodox Judaism or a sect of Noahidism. With the exception of Rabbi Bar-Ron's, who distinguishes himself from other Jewish sects based on a halakhic point, Noahide texts do not discriminate against other Noahides. I believe this shows one of three things: (1) we cannot say Noahide sects fundamentally exist, even from an outside perspective; (2) Noahides themselves do not identify with a sect or see themselves divided by sectarianism; or (3), Noahides are aware of sectarian divides, but these divisions do not cause friction. I think we may begin to see sectarianism develop more rigidly and for identification with sects to become a point of interest to Noahides as Noahide culture grows, as self-understanding grows, and as communities become larger and more exclusive to geographical zones rather than centered around online interaction. 


\section{CONCLUSION}

I would like to close this work first by offering some suggestions for further

research. It is clear to me that the topic of contemporary Noahidism would greatly benefit from detailed ethnographic work, or at least interviews of Noahide practitioners. The information contained in the primary contemporary texts I have analyzed influence Noahide identity, but we can only imagine how many more factors exist to shape Noahide individuals. Our understanding of the Noahide movement would especially benefit from ethnographic work in spaces like the virtual yeshivot, worldwide Noahide conferences, and the apparently robust Noahide communities in the Philippines.

I also welcome a review of the primary literature similar to mine in order to compare my findings with those of another researcher. There are also a few texts which I did not include in my analysis because I was unaware of them at the time. Aaron Lichtenstein's work (The Seven Laws of Noah) and Chaim Clorfene's new book (The World of the Ger) are two examples of texts which should be included in a subsequent analysis of the primary literature. It is also possible to analyze internet activity on social media platforms (of which there is plenty) and activity on independent websites.

The five factors I examined here were chosen because they feature so frequently in the primary texts. My selection was not whimsical. These factors seem to me to be the foundations of Noahide identity. The way in which the primary texts address these topics suggests as much, as does the survey data. And considering that very little academic work 
exists on Noahide identity, I found it important to unpack these broader topics, otherwise more detailed work could not be reasonably completed.

In regards to the survey, I would like to address the numerous free responses which can be found as the last question of the survey. These responses also indicate the importance of these five factors on contemporary Noahide identity. If one ventures to read through them, it is clear several of the issues I have pointed out in this thesis are indeed manifesting themselves in the contemporary Noahide world. There is a fair amount of confusion regarding the scope of Noahide law and ritual. There is a general reluctance to categorize Noahidism as a religion, or to even use the word "Noahidism" to refer to the movement, despite its rather evident religious nature. There is also great frustration around the topic of integration with the Jewish community. Conversion to Orthodoxy is an oft mentioned concern. Unfortunately, the solution to many of these issues are contingent upon the resolution of other dilemmas. It should not be surprising that so many difficulties exist. After all, this is a rather unique phenomenon in the history of religions and especially in the history of Judaism. Judaism is giving birth (or resurrecting, in some eyes) to a new religious order, opening its doors to a potentially massive number of people. This endeavor is complicated by the fact that the terms in which this phenomenon is unfolding are very much decentralized. In other words, there is no one person or group of people running the show. This makes the general study of Noahide identity difficult. 
It is also possible that Noahide identity may continue to shift rapidly, depending on whether Noahides and rabbis come to a consensus regarding the nature of Noahide law and ritual. Identity may also shift as online and physical Noahide communities grow, as a second and even third generation of Noahides are born, or as interaction with Jewish communities increases. The results I have compiled here may be obsolete in the next 50 years.

But even then, many observations made in this thesis are interesting for the current Noahide movement and for individuals studying new religious movements in the 20th and 21 st centuries. The primary literature invokes excerpts from rabbinic sources lauding the universal nature of the law. Increased global awareness and need for interreligious dialogue have driven the purported universalistic allure of Noahide rhetoric, although it is clear Noahide thinkers and writers are interested in religious exclusivism. The authors of these texts insist Noahide ideology is non-religious, but this cannot be reconciled with their conviction that Noahidism and proper observance of the Noahide laws must be premised upon belief in the Jewish God, Jewish revelation, and Jewish notions of spiritual salvation. This tension would be of interest to those examining the current state of interfaith dialogue and the way contemporary religions portray their conceptions of religious pluralism or inclusivism.

The lack of a ritual tradition in the Noahide world is also interesting from a psychological and anthropological perspective in attempting to understand the place and importance of ritual in the religious psyche. The discontent found in some of the free 
responses is palpable, and such discontent could indicate how religious life is sought primarily to organize and play out an individual's symbolic life, rather than merely provide ethical tenets or laws which to live by. It would also be good to examine how Noahide ritual develops over the years and how this development is tied to physical and online communities, particularly since the primary literature has already employed its own schema to circumvent the issue of ritual. How might these philosophical and theological innovations play out as they are disseminated among different communities? From looking at the survey data and the autobiographical works, I expect to see Noahide communities move in the direction of greater ritual freedom.

Conversion is one such ritual that will have to be addressed, but there seems to be no rush. Noahides have relatively easy access to Noahide communities and Noahide identity. Self-identification and identification from the community appears to be rather fluid and contingent upon public acceptance of the Noahide laws and Jewish principles of faith, to the exclusion of non-Jewish religious beliefs. One way in which Noahides deepen their identity is through intensive study of Jewish texts, whether in a communal or individual setting. Study also forms a great part of Noahide ritual life, as does prayer, even if these activities have not yet been standardized throughout the Noahide world.

The propensity to seek Orthodox Jewish conversion is in part driven by disappointment with the current state of Noahidism (i.e. a lack of ritual, lack of consensus on the scope of Noahide law, etc.), but at other times Noahidism is usually seen as a welcomed alternative to the rigors of Orthodox conversion and daily life. The information 
I have collected bears out the fact that Orthodox conversion is a hot topic among Noahides, but that Noahidism is not a gateway to Orthodox conversion. This is true despite the fact that many Orthodox communities have been incredibly hospitable to Noahides seeking rabbinic guidance. This is so true, in fact, that Noahide groups have settled among Orthodox sectarian lines, although this is not always the case. I also suspect that Noahide groups will continue to develop in cooperation with Orthodox Jewish communities, at least for the near future, regardless of the way in which Noahide law is ultimately interpreted and standardized. If the Noahide laws are interpreted as general prescriptions, this would give Noahide communities great freedom to legislate and adjudicate the details of the seven laws for their constituents. Nevertheless, Noahide communities will want to continue their intimate relationship with Orthodoxy because this relationship provides Noahides with spiritual legitimacy. And we should not forget that the celebration of Jewish high holidays would also take place in conjunction with Jewish communities.

But from an eschatological perspective, the narrative we find in Isaiah indicates the inevitable relationship between the Jewish and non-Jewish worlds; the former is destined to guide humanity into an epoch of spiritual and political peace. We can infer from the text that this would be done by enforcing a worldwide legal code. Although there is no explicit mention of this, it gives contemporary Noahides much to live up to and much to look forward to. 


\section{REFERENCES}

\section{Textual Sources:}

Ariel, Yaakov. "Jews and New Religious Movements: An Introductory Essay." Nova Religio: The Journal of Alternative and Emergent Religions 15, no. 1 (2011): 5-21.

Bar-Ron, Michael Shelomo. Guide for the Noahide: A Complete Manual for Living by the Noahide Laws. 2nd ed. Springdale, AR: Lightcatcher Books, 2010.

Batnitzky, Leora Faye. How Judaism became a religion: an introduction to modern Jewish thought. Princeton, NJ: Princeton University Press, 2011.

Berlin, Adele, and Marc Zvi Butler. The Jewish Study Bible. Edited by Michael Fishbane. New York: Oxford University Press, 2004.

Brauner, Reuven, trans. Laws of Kings and Wars: Translated from the Rambam's Mishne Torah. Raanana: Talmudic Books, 2012.

Cecil, Alan W. The Noahide Code: A Guide to the Perplexed Christian. Pompano Beach: Academy of Shem, 2006. . Secular by Design: A Philosophy of Noahide Laws and Observances. Pompano Beach: Academy of Shem, 2011.

Charles, Robert Henry. The Apocrypha and Pseudepigrapha of the Old Testament in English. Oxford: At the Clarendon Press, 1913.

Cohen, Daphne. The Colorful Rainbow Dream. Delhi: Indo American Books, 2008.

Cohn-Sherbok, Dan. Judaism and Other Faiths. New York: St. Martin's Press, 1994. . Judaism Today. New York: Continuum International Publishing Group, 2010.

Cowen, Shimon Dovid. The Theory and Practice of Universal Ethics: The Noahide Laws. New York: Institute for Judaism and Civilization, 2014.

Dallen, Michael. The Rainbow Covenant: Torah and the Seven Universal Laws. Springdale, AR: Lightcatcher Books, 2003. 
David Cohen, Yakov. Divine Image. New York: Institute of Noahide Code, 2006.

David Davis, J. Finding the God of Noah: The Spiritual Journey of a Baptist Minister from Christianity to the Laws of Noah. Hoboken, NJ: KTAV Publishing House, 1996.

"Daily Prayers." In Service From the Heart: Renewing the Ancient Path of Biblical Prayer and Service, edited by Michael Katz, Yechiel Sitzman, Pam Rogers, Larry Rogers, and Nancy January, 100. Rose, OK: OKBNS Press, n.d. PDF e-book. 2007.

Ginzburg, Yitshak, and Moshe Genuth. Kabbalah and Meditation for the Nations. GalEinai Publication Society, 2007.

Green, Yosef. "Universalism and/or Particularism.” Jewish Bible Quarterly 30, No. 1. (2002)

Hammer, Olav. The Cambridge Companion to New Religious Movements. Cambridge: Cambridge University Press, 2012.

Hanke, Kimberly E. Turning to Torah: The Emerging Noachide Movement. Northvale, New Jersey: J. Aronson, 1995.

Hazony, Yoram. The Philosophy of Hebrew Scripture. New York: Cambridge University Press, 2012.

Hexham, Irving, and Karla O. Poewe. New religions as global cultures: making the human sacred. Boulder, CO: Westview Press, 1997.

Hunt, Stephen. Alternative religions: a sociological introduction. Aldershot, Hampshire, England: Ashgate, 2003.

Kaplan, Aryeh. Meditation and Kabbalah. San Francisco: Weiser Books, 1985. . Jewish Meditation: A Practical Guide. New York: Schocken Books, 1985.

Kaplan, Jeffrey. Radical religion in America: millenarian movements from the far right to the children of Noah. Syracuse University Press, 1997.

Kravel-Tovi, Michal. "Bureaucratic gifts: Religious conversion, change, and exchange in Israel." American Ethnologist 41, no. 4 (2014): 714-727. 
Maimonides, Moses. The Guide for the Perplexed. Translated by M. Friedlaender. New York: Barnes and Noble, 2004.

Mather, Richard. "Noahides and the Celebration of Passover." Arutz Sheva. March 31, 2013. Accessed April 6, 2015. http://www.israelnationalnews.com/Articles/ Article.aspx/13069.

Neusner, Jacob. The Mishnah: A New Translation. New Haven, CT: Yale University Press, 1988.

. The Theology of the Oral Torah: Revealing the Justice of God. Montreal: McGill-Queen's University Press, 1999.

Novak, David. Natural Law in Judaism. New York: Cambridge University Press, 1998.

Novak, David, and Matthew Lagrone. The Image of the Non-Jew in Judaism. 2nd ed. Portland, OR: Littman Library of Jewish Civilization, 2011.

Rakover, Nahum. "Jewish Law and the Noahide Obligation to Preserve Social Order." Cardozo L. Rev. 12 (1990): 1073.

Rosenberg, Irene Merker. "The Seven Noahide Laws: Of Monkey Brains and Courts." Rutgers Journal of Law and Religion 6, no. 1 (2004): 4.

Rosenthal, Gilbert S. "Hasidei umot ha-olam: a remarkable concept." Journal of Ecumenical Studies 48.4 (2013): 467+.Academic ASAP. Web. 4 Aug. 2014.

Rothstein, Gidon. "Involuntary Particularism: What the Noahide Laws Tell Us About Citizenship and Alienage." Geo. Immigr. LJ 18 (2003): 543.

Rynhold, Daniel. Two Models of Jewish Philosophy. New York: Oxford University Press, 2005.

Schiffman, Lawrence H. Who was a Jew?: rabbinic and halakhic perspectives on the Jewish Christian schism. KTAV Publishing House, Inc., 1985.

Scherman, Nosson. The Chumash: The Torah, Haftaros and Five Megillos. 11, Stone ed. Brooklyn, NY: Mesorah Publications, 2012. 
Schwartzschild, Steven. "Do Noahides Have to Believe in Revelation?" Jewish Quarterly Review 52 (1962): 297-309, 53 (1962): 29-59.

Silberstein, Laurence J., and Robert L. Cohn. The Other in Jewish thought and history: constructions of Jewish culture and identity. New York: New York University Press, 1994.

Smith, Jonathan Z. "Religion, Religions, Religious." In Critical Terms for Religious Studies, 269-84. Chicago: The University of Chicago Press, 1998.

Solomon, Norman. "Towards a Jewish Theology of Trilateral Dialogue." Islam and Global Dialogue. Religious Pluralism and the Pursuit of Peace, Aldershot (2005): 203-214.

Stone, Suzanne Last. "Sinaitic and Noahide Law: Legal Pluralism in Jewish Law." Cardozo L. Rev. 12 (1990): 1157.

Sulomm Stein, David, ed. JPS Hebrew-English Tanakh. 2nd ed. Philadelphia: Jewish Publication Society, 2003.

Villegas, Emmanuel, Michael Schulman, and Chaim Reisner, eds. Noahide Seventh Day Prayers: Suggested Prayers for Noahide Community Services and Personal Worship. Davao City: Qelihat Chasidi Ha-Umot, 2013.

Vollmar, Birgit. Noahs Kinder: Die Glaubensbewegung der Noachiden in der Gegenwart. Tectum Verlag, 2012.

Weber, Max, Peter Baehr, and Gordon C. Wells. The Protestant ethic and the "spirit" of capitalism and other writings. New York: Penguin Books, 2002.

Weiner, Moshe. The Divine Code. Edited by Micahel Schulman. Translated by Yosef Schulman. 2nd ed. Vol. 1. Ask Noah International, 2011.

Weiner, Moshe, J. Immanuel Schochet, Michael Schulman, Joseph Regenstein, and Arthur Goldberg. Go(o)d for You: The Divine Code of 7 Noahide Commandments. 2nd ed. Ask Noah International, 2013.

Weiner, Moshe, and J. Immanuel Schochet. Prayers, Blessings, Principles of Faith, and Divine Service for Noahides. Ask Noah International, 2014. 
Yitzchaki, Shlomo. Pentateuch: With Targum Onkelos, Haphtaroth and Rashi's Commentary: Genesis. Translated by M. Rosenbaum and A. M.

Silberman. New York: Hebrew Publishing Company, 1973.

Internet Sources:

Brill, Alan. "Judaism and Other Religions." Judaism and Other Religions. 2004. Accessed October 8, 2015. http://www.bc.edu/content/dam/files/research_sites/cjl/texts/ cjrelations/resources/articles/Brill.htm.

Clorfene, Chaim, and Yakov Rogalsky. "Introduction to the Noahide Laws." Noahide The Ancient Path. Last modified May 22, 2011. Accessed 5 October 2014. noahide-ancient-path.co.uk/index.php/judaism-articles/2011/05/the-path-of-therighteous-gentile/.

HaLevi, Ezra. "Sanhedrin Recognizes Council to Teach Humanity 'Laws of Noah' - A Group of Non-Jewish Delegates Have Come to Jerusalem to Pledge Their Loyalty to the Laws of Noah." Arutz Sheva Israel National News. October 1, 2006.

Accessed October 3, 2016. http://www.israelnationalnews.com/News/News.aspx/ $\underline{96347 .}$.

Israel National News. "Accepting the Laws of Noah." WeJew.com. undefined. October 5, 2009. http://wejew.com/media/6330/Accepting_the_Laws_of_Noah/.

IsraelNN Staff. "Four New Noahides Welcomed into the Fold in Jerusalem - Four Gentiles Declared Their Acceptance of the Seven Laws of Noah." Arutz Sheva Israel National News. May 10, 2009. Accessed October 3, 2016. http:// www.israelnationalnews.com/News/News.aspx/133714.

"Main Page." English WikiNoah RSS. 2012. Accessed October 7, 2015. http:// wikinoah.org/index.php?title=Main_Page.

"Orthodox Rabbinic Statement on Christianity." Center for Jewish-Christian Understanding and Cooperation. December 3, 2015. Accessed January 2, 2016. http://cjcuc.com/site/2015/12/03/orthodox-rabbinic-statement-on-christianity/.

"Sanhedrin Establishes Council to Teach Humanity Laws of Noah." Israel Faxx 10 Jan. 2006. Business Insights: Essentials. Web. Accessed October 8, 2015. http://www.israelnationalnews.com/News/News.aspx/96347 
Schachter, Jacob, H. Freedman, and Rabbi Dr. I Epstein. The Babylonian Talmud: Seder Nezikin: Tractate Sanhedrin. http://halakhah.com/sanhedrin/index.html

Schwartz, Yoel, and Yitzhak A. Oked Sechter. "Noahide Commandments." Oklahoma B'nai Noah Society, 2004. Accessed June 7, 2015. http://www.okbns.org/ R Schwartz Intro.html.

Sitzman, Yechiel. "Theology and History." Oklahoma B'nai Noah Society. Last modified 2003. Accessed December 15, 2014. http://www.okbns.org/Theo_History.html.

WeJew. Israel and Jewish Videos. Accepting The Laws Of Noah. October 5, 2009. Accessed October 03, 2016. http://wejew.com/media/6330/Accepting the Laws of Noah/.

Williams, Thomas D. "Orthodox Rabbis Issue Groundbreaking Declaration Affirming 'Partnership' With Christianity." Breitbart. December 17, 2015. Accessed January 2, 2016. http://www.breitbart.com/national-security/2015/12/17/orthodox-rabbisissue-groundbreaking-declaration-affirming-partnership-christianity/. 


\section{APPENDICES}

\section{Appendix A - IRB Approval from FIU}

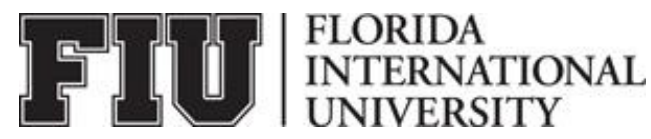

Office of Research Integrity Research Compliance, MARC 414

\section{MEMORANDUM}

To:

Dr. Tudor Parfitt

CC:

File

From:

Maria Melendez-Vargas, MIBA, IRB Coordinator

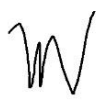

Date:

November 9, 2015

Protocol Title: $\quad$ "From the Fall to the Flood and Beyond: Navigating Identity in

Contemporary Noahidism"

The Social and Behavioral Institutional Review Board of Florida International University has approved your study for the use of human subjects via the Expedited Review process. Your study was found to be in compliance with this institution's Federal Wide Assurance (00000060).

IRB Protocol Approval \#: IRB-15-0408

IRB Approval Date: $11 / 06 / 15$

TOPAZ Reference \#:

104222

IRB Expiration Date: 11/06/16

As a requirement of IRB Approval you are required to:

1) Submit an IRB Amendment Form for all proposed additions or changes in the procedures involving human subjects. All additions and changes must be reviewed and approved by the IRB prior to implementation.

2) Promptly submit an IRB Event Report Form for every serious or unusual or unanticipated adverse event, problems with the rights or welfare of the human subjects, and/or deviations from the approved protocol.

3) Utilize copies of the date stamped consent document(s) for obtaining consent from subjects (unless waived by the IRB). Signed consent documents must be retained for at least three years after the completion of the study.

4) Receive annual review and re-approval of your study prior to your IRB expiration date. Submit the IRB Renewal Form at least 30 days in advance of the study's expiration date.

5) Submit an IRB Project Completion Report Form when the study is finished or discontinued.

Special Conditions: N/A

For further information, you may visit the IRB website at http://research.fiu.edu/irb. 


\section{Appendix B - Adult Online Consent Form}

\section{FIU /}

\section{ADULT ONLINE CONSENT TO PARTICIPATE IN A RESEARCH STUDY \\ Noahide Questionnaire}

\section{PURPOSE OF THE STUDY}

You are being asked to be in a research study. The purpose of this study is to identify various sociological factors that are influencing Noahidism.

\section{NUMBER OF STUDY PARTICIPANTS}

If you decide to be in this study, you will be one of 250 people in this research study.

\section{DURATION OF THE STUDY}

Your participation will require 30-60 minutes.

\section{PROCEDURES}

If you agree to be in the study, we will ask you to do the following things:

1. answer 33 questions regarding personal information related to your demographics, your practices as a Noahide, personal religious history, relationship with Jewish communities, and relationship with Noahide communities. If you prefer not to respond to any of these questions, you may select the "I prefer not to respond" option.

2. self-identify and/or volunteer to be interviewed individually at a later date.

\section{RISKS AND/OR DISCOMFORTS}

There are no reasonably foreseeable risks and/or discomforts associated to completing this study.

\section{BENEFITS}

The following benefits may be associated with your participation in this study:

1. Noahide community leaders and Noahide men/women could gain an understanding of the structural and philosophical issues that are bearing on their community in particular and on Noahidism in general.

2. Increased understanding could help Noahide and Jewish community leaders allocate their resources in a more efficient way to meet the needs of their community.

3. Scholars in the Religious Studies discipline could gain a better understanding of the various philosophical, economic, political, religious, and regional influences that are at play in Judaism, one of the world's most influential religions.

\section{ALTERNATIVES}

Page 1 of 2 
There are no known alternatives available to you other than not taking part in this study. However, any significant new findings developed during the course of the research which may relate to your willingness to continue participation will be provided to you.

\section{CONFIDENTIALITY}

The records of this study will be kept private and will be protected to the fullest extent provided by law. In any sort of report we might publish, we will not include any information that will make it possible to identify a subject. Research records will be stored securely and only the researcher team will have access to the records. However, your records may be reviewed for audit purposes by authorized University or other agents who will be bound by the same provisions of confidentiality.

\section{COMPENSATION \& COSTS}

You will not receive a payment or compensation for your participation. You will not be responsible for any costs to participate in this study.

\section{RIGHT TO DECLINE OR WITHDRAW}

Your participation in this study is voluntary. You are free to participate in the study or withdraw your consent at any time during the study. Your withdrawal or lack of participation will not affect any benefits to which you are otherwise entitled. The investigator reserves the right to remove you without your consent at such time that they feel it is in the best interest.

\section{RESEARCHER CONTACT INFORMATION}

If you have any questions about the purpose, procedures, or any other issues relating to this research study you may contact Patrick J. Villalonga at Florida International University, 786-473-5507, pvil1015@,fiu.edu.

\section{IRB CONTACT INFORMATION}

If you would like to talk with someone about your rights of being a subject in this research study or about ethical issues with this research study, you may contact the FIU Office of Research Integrity by phone at 305-348-2494 or by email at ori@fiu.edu.

\section{PARTICIPANT AGREEMENT}

I have read the information in this consent form and agree to participate in this study. I have had a chance to ask any questions I have about this study, and they have been answered for me. By clicking on the "consent to participate" button below I am providing my informed consent.

(Insert Consent to Participate Button Here on the Website) 


\section{Appendix C - Noahide Individuals Survey}

Q1 - Thank you for your interest in the Noahide Questionnaire! This survey is being conducted as part of an graduate academic thesis by Patrick J. Villalonga at Florida International University (FIU) in Miami, FL under the guidance of the Center for Global Jewish Communities - FIU, the Jewish Museum of Florida - FIU, Dr. Tudor Parfitt (Ph.D.), and Dr. Oren Stier (Ph.D.). This questionnaire intends to survey Noahides living all around the world in order to better understand the current state of Noahidism as a blossoming, global phenomenon. All information will be used anonymously unless you submit your name at the end of the survey. Please take the survey only once and feel free to suggest it to other Noahides. By consenting to this survey, you are claiming that you currently identify as a Noahide and would like for your information to be used in this academic thesis. Do you consent to this survey?

\begin{tabular}{|l|r|}
\hline Yes & 248 \\
\hline No & 6 \\
\hline Total & 254 \\
\hline
\end{tabular}

Q2A - Unfortunately you do not meet the requirements of this survey or you have chosen not to disclose your information. Thank you for your time.

Q3 - Through what medium do you first recall being exposed to Noahidism?

\begin{tabular}{|l|r|r|}
\hline In person & 71 & $29.96 \%$ \\
\hline Through a book & 18 & $7.59 \%$ \\
\hline Online & 128 & $54.01 \%$ \\
\hline Another form of media & 6 & $2.53 \%$ \\
\hline I prefer not to respond & 3 & $1.27 \%$ \\
\hline I do not remember & 11 & $4.64 \%$ \\
\hline Total & 237 & $100 \%$ \\
\hline
\end{tabular}


Q4A - What was the religious affiliation of the person who exposed you to Noahidism?

\begin{tabular}{|l|r|r|}
\hline Noahide & 17 & $24.29 \%$ \\
\hline Orthodox Jew & 36 & $51.43 \%$ \\
\hline Other Jewish denomination & 3 & $4.29 \%$ \\
\hline Christian & 7 & $10.00 \%$ \\
\hline Other & 3 & $4.29 \%$ \\
\hline Agnostic or atheist & 0 & $0.00 \%$ \\
\hline No particular affiliation & 3 & $4.29 \%$ \\
\hline I prefer not to respond & 1 & $1.43 \%$ \\
\hline I do not remember & 0 & $0.00 \%$ \\
\hline Total & 70 & $100 \%$ \\
\hline
\end{tabular}

Q4B - What was the religious affiliation of the person, organization, or community that suggested this book to you?

\begin{tabular}{|l|r|r|}
\hline Noahide & 1 & $5.56 \%$ \\
\hline Orthodox Jew & 3 & $16.67 \%$ \\
\hline Other Jewish denomination & 0 & $0.00 \%$ \\
\hline Christian & 0 & $0.00 \%$ \\
\hline Other & 1 & $5.56 \%$ \\
\hline None & 1 & $5.56 \%$ \\
\hline I came across this text on my own & 12 & $66.67 \%$ \\
\hline I prefer not to respond & 0 & $0.00 \%$ \\
\hline I do not remember & 0 & $0.00 \%$ \\
\hline Total & 18 & $100 \%$ \\
\hline
\end{tabular}


Q4C - What was the religious affiliation of the person, organization, or community that suggested this webpage to you?

\begin{tabular}{|l|r|r|}
\hline Noahide & 22 & $17.60 \%$ \\
\hline Orthodox Jew & 38 & $30.40 \%$ \\
\hline Other Jewish denomination & 6 & $4.80 \%$ \\
\hline Christian & 4 & $3.20 \%$ \\
\hline Other & 4 & $3.20 \%$ \\
\hline None & 4 & $3.20 \%$ \\
\hline I came across this webpage on my own & 45 & $36.00 \%$ \\
\hline I prefer not to respond & 0 & $0.00 \%$ \\
\hline I do not remember & 2 & $1.60 \%$ \\
\hline Total & 125 & $100 \%$ \\
\hline
\end{tabular}

Q4D - What was the religious affiliation of the person, organization, or community that suggested this media to you?

\begin{tabular}{|l|r|r|}
\hline Noahide & 0 & $0.00 \%$ \\
\hline Orthodox Jew & 5 & $83.33 \%$ \\
\hline Other Jewish denomination & 0 & $0.00 \%$ \\
\hline Christian & 0 & $0.00 \%$ \\
\hline Other & 0 & $0.00 \%$ \\
\hline None & 0 & $0.00 \%$ \\
\hline I came across this media on my own & 1 & $16.67 \%$ \\
\hline I prefer not to respond & 0 & $0.00 \%$ \\
\hline I do not remember & 0 & $0.00 \%$ \\
\hline Total & 6 & $100 \%$ \\
\hline
\end{tabular}


Q5 - In general, what was the genre of the text, webpage, or media that exposed you to Noahidism?

\begin{tabular}{|l|r|r|}
\hline Judaism & 119 & $80.41 \%$ \\
\hline Christianity & 7 & $4.73 \%$ \\
\hline Religion & 9 & $16.89 \%$ \\
\hline Philosophy & 5 & $3.38 \%$ \\
\hline Law & 9 & $6.08 \%$ \\
\hline History/Anthropology & 9 & $6.08 \%$ \\
\hline Other & 0 & $0.00 \%$ \\
\hline I prefer not to respond & 1 & $0.68 \%$ \\
\hline I do not remember & 148 & $100 \%$ \\
\hline Total & & \\
\hline
\end{tabular}

Q6 - In approximately what year did you become aware of Noahidism?

\begin{tabular}{|l|r|r|}
\hline $\mathbf{2 0 1 0 - 2 0 1 6}$ & 95 & $41.48 \%$ \\
\hline $\mathbf{2 0 0 5 - 2 0 0 9}$ & 54 & $23.58 \%$ \\
\hline $\mathbf{2 0 0 0 - 2 0 0 4}$ & 40 & $17.47 \%$ \\
\hline $\mathbf{1 9 9 0 - 1 9 9 9}$ & 19 & $8.30 \%$ \\
\hline $\mathbf{1 9 8 0 - 1 9 8 9}$ & 16 & $6.99 \%$ \\
\hline $\mathbf{1 9 5 0 - 1 9 7 9}$ & 1 & $0.44 \%$ \\
\hline I don't know & 2 & $0.87 \%$ \\
\hline I prefer not to respond & 2 & $0.87 \%$ \\
\hline Total & 229 & $100 \%$ \\
\hline
\end{tabular}


Q7 - In approximately what year did you begin to identify yourself as a Noahide?

\begin{tabular}{|l|r|r|}
\hline $\mathbf{2 0 1 0 - 2 0 1 6}$ & 105 & $46.46 \%$ \\
\hline $\mathbf{2 0 0 5 - 2 0 0 9}$ & 55 & $23.34 \%$ \\
\hline $\mathbf{2 0 0 0 - 2 0 0 4}$ & 23 & $10.18 \%$ \\
\hline $\mathbf{1 9 9 0 - 1 9 9 9}$ & 17 & $7.52 \%$ \\
\hline $\mathbf{1 9 8 0 - 1 9 8 9}$ & 12 & $5.31 \%$ \\
\hline $\mathbf{1 9 5 0 - 1 9 7 9}$ & 1 & $0.44 \%$ \\
\hline I don't know & 5 & $2.21 \%$ \\
\hline I prefer not to respond & 7 & $3.10 \%$ \\
\hline Total & 225 & $100 \%$ \\
\hline
\end{tabular}

Q8 - Have you ever attempted conversion to Judaism of any kind (i.e. orthodox, reform, conservative, etc.)?

\begin{tabular}{|l|r|r|}
\hline I am currently trying to convert & 17 & $7.59 \%$ \\
\hline I have tried, after I became a Noahide & 14 & $6.25 \%$ \\
\hline I have tried, before I became a Noahide & 17 & $7.59 \%$ \\
\hline I have never tried, but I am interested in converting & 44 & $19.64 \%$ \\
\hline I was interested at one point, but not anymore & 65 & $29.02 \%$ \\
\hline I have never tried, and I am not interested in converting & 51 & $22.77 \%$ \\
\hline I prefer not to respond & 16 & $7.14 \%$ \\
\hline Total & 224 & $100 \%$ \\
\hline
\end{tabular}

Q9 - Why did you not complete conversion to Judaism? Please feel free to write anything regarding this.If you prefer not to respond, please write "I prefer not to respond."

uneducated efforts

Discussions with Jews stopped

The city I was living in at the time did not have an orthodox community but through the rabbi there I learned about being a Noahide.

I did convert Orthodox in 2000 
nothing orthodox near me

Few reasons, in my opinion

found out about Noahide

Synagogue was to far

My wife and I would have had to move away from our children and grandchildren, in order to live in an Orthodox community. It was a decision we were not prepared to make.

The city I lived in at the time did not have an orthodox community and we couldn't afford to move but after talking to the rabbi is when we were aware of being a Noahide

Very involved conversion process

I become reform jewish now (2015)

It was made far too difficult for me.

Hashem stopped me

There is no Jewish community near me. The Rabbi's I spoke with were not receptive, even tho my mother's side of the family were Spanish Jews forced to convert to christianity under threat of death.

My finances and my disability made it very hard to.cply with requirements. I believe HaShem has work fore to do as a Noahide/ Ger

Not necessary for Noahides.

I decided not to convert for many reasons, I think primarily because it would interfere with my life with my kids and grandkids, plus keeping all of the mitzvot forever is hard with steep consequences for failure. And status of Noahide is a very legitimate thing, and we can reach the level of a kohen gadol, whereas a Jew cannot necessarily if he is born this and that. I am not ruling out an orthodox conversion one day, as the influence and rewards are great.

Because Noachide is a better option.

NA

It's very complicated. The most simple version of the answer is if $i$ had remained single, and hadn't relocated to Chicago (where no orthodox synagogue wanted to accept a transfer), i would have completed an ashkenaz orthodox conversion $<$ Not a small undertaking.

Did complete a conservative conversion. Have learned since it is not accepted.

1st time was due to family difficulties 2nd time i quit due to Rabbi Katz' Ger exposure

My wife didn't agree.

I am still trying to understand what the foundations are for considering Torah to certainly be true.

judism was myz first choice and $\mathrm{i}$ was already started to keep mizvots and learning but after $\mathrm{i}$ spoke to the rabbi of chabad of malta he told me that it is better to become a noahide than a jew so now $i$ am learning to be a noahide. 
Was not the best time for my family. Plus we have something's we need to learn to that we truly want to be Jews.

I prefer not to respond

I had a desire in the beginning, but I did not increase my will and desire to keep the Torah and mitzvot in the proper spirit. And I did not increase my will and desire to gradually assume a proper Jewish identity and successfully assimilate into the native Jewish culture, in the proper spirit. I was not rejected, rather I stopped the process of my own volition. To clarify - during my conversion I was never turned away, and was well received by all in the Jewish community. Further, I retain good, close, and heartfelt relations with the Jews I came to befriend and study under. I remain a Ben Noach and continue to walk the path of the just with the fear of Heaven, according to the Written and Oral Torah, as preserved and taught by those Jews identifying as Torah observant, i.e. Orthodox.

I just do not know if it is what I want yet.

Rabbi was not receptive of the process

Q10 - How do you feel the process of conversion is going for you? Please feel free to write anything regarding this.If you prefer not to respond, please write "I prefer not to respond."

slowly, due to being married

nice

slowly but I'm determined

prefer not to respond

very slowly

I am not sure. I actually converted under a reform rabbi (with Beit Din, hatafat dam brit, tevilah). But I would prefer an orthodox conversion which does not seem to be available at the time. Unless I relocate.

accepted in Reform

I prefer not to respond

Difficult test. Need a lot of patience, will and faith.

prohibitively slow

I prefer not to respond

I prefer not to respond

Almost impossible but full of hopes and miracles

old and deaf, if they show interest i do not hear them 
It is very hard, I accept the difficulty as an inherent quality of Judaism. If I succeed I will be a proud Jew, if I fail I will be a proud Noachide.

Going well. I learn with my sponsoring rabbi once a week

I prefer not to respond.

Q11 - Have you been affiliated with any other religion or religious movement prior to identifying yourself as a Noahide?

\begin{tabular}{|l|r|r|}
\hline Catholicism & 46 & $20.72 \%$ \\
\hline Christianity & 146 & $65.77 \%$ \\
\hline Messianic Judaism & 51 & $22.97 \%$ \\
\hline Judaism & 14 & $6.31 \%$ \\
\hline Buddhism & 8 & $3.60 \%$ \\
\hline Hinduism & 3 & $1.35 \%$ \\
\hline Janism & 1 & $0.45 \%$ \\
\hline Islam & 5 & $2.25 \%$ \\
\hline Atheism & 15 & $6.76 \%$ \\
\hline Other & 16 & $7.21 \%$ \\
\hline None & 14 & $6.31 \%$ \\
\hline I prefer not to respond & 5 & $2.25 \%$ \\
\hline Total & 222 & $100 \%$ \\
\hline
\end{tabular}

Q12 - In brief, for what reason did you begin to identify yourself as a Noahide? What about Noahidism attracted you or continues to attract you? If you prefer not to respond, please type in "I prefer not to respond."

Divine Authority.

It is the closest thing to Judism. However I'm just beginning to scratch the surface. I would like to have a group of people to identify with, it's very lonely leaving Christianity. I am very cautious to not "join" a "new" religion.

after years of searching for truth have having left christianity, i knew i still believed in the God of Israel, the only God I'd ever known. in my spiritual search, i knew i had to return to Him. once $i$ did that, my spiritual search had ended and i've been relearning about God (unlearning all the things i'd picked up in christianity) and what it means to follow Him ever since. 
Noahides to just talk the talk, they walk it. I'm sick of Christians, spurred on by their pastors and priests, showing by their actions as nothing more than pseduo-Christians. They treat their fellow man as a prey and they are the predator, all believing their behavior is with Christ's blessing. Christ fed his fellow man, he healed them, he cared. Christians don't care about the poor, the elderly, they marginalized. Jews have stood up for kindness on a whole. Christians were rare in 1960's race riots like they are today. Jews mobilize and help. I admire them.

Torah makes sense to me, but I am not jewish and my wife would never convert with me. I enjoy reading and studying torah, but understand that I am not Jewish. There seems to be a core philosphy that is tied to our human experience. - I never felt comfortable with christianity or it's evangelist.

Through years of study of the "Old Testament" I came to realize that the things I was tought in Christianity were not consistant with what I was reading. Thanks to Rabbi's like Tovia Singer and Michael Skobac I was able to fully leave Christianity. I consider myself a Ger which is a deeper understanding of Noahide.

Being able to have a relation to G-d

I saw the inaccuracy of Christianity. I saw how Christians mistranslated the Bible and saw how they tried to steal scriptures meant for Jews. I did not know that it was called Noahidism until some time passed after I gave up on the deception known as Christianity.

Judaism and noachidism[sp?] make sense to me, unable to live an observant lifestyle so trying this path. Logically based, with tradition and room for individuality.

I love the Torah of G-d.

It is sensible, doesn't ask one to believe impossible things and its practical. It doesn't claim to be the only way .

While a child I had jewish neighbors that used to invite me for Kabbalat Shabbath at their home because I was very curious about what those beautiful songs were all about. Despite I was raised as a christian I never fully accepped the idea of a man beeing a god (?'?). When I was about 21 I met a group of Torah studies guided by jewish traditional literature. Since then, I learned hebrew and started to study on my own. I deeply share with jews its religious views. There was I time when I believed that it was enought for beeing a true "soul jew". Then I realise it was wrong. I used do keep the mitzvot and tried pray $3 x$ every day. But then I saw a rabbi saying it was not for non-jews. A friend of mine from that Torah study group took part of Bney Baruch that told him about what a noahide is. Since then I struggle with my religous identity and how to carry on with a ballanced "religous life" or "ritual life". But I try to absorb to my life as much as I can from Torah ethic principles.

inaccuracies, mis translations NT

Difficulties in converting to Judaism

I have been interested in converting to Judaism. I was raised Catholic, but I now reject it and the validity of the New Testament broadly. Noahidism is both an alternative to conversion, and if I decide to further explore conversion, will be an intermediate step to conversion.

My family is associated with Conservative Judaism and since these conversions are fake, I rather become a noahide. 
I could not believe in the christian doctrin. The noahide doctrine appears realistic for the live.

I wish to convert to Judaism, but am not able to at the moment.

After many years of searching for truth and studying the Bible, as well as alternative 'New Age' type 'religions', which included the mystical teachings of Judaism, the Kabbalah; the OT/Torah to me and had explanations to questions and issues that had always puzzled me in the Christian traditions. Having gotten feed up with 'the Church' I had eventually left, eventually began my own personal search, and began searching and asking questions in areas 'the Church' would consider forbidden. My bible had been gathering dust on the shelf for years, but several books I read in my search drew me back into the scriptures. Eventually, I began reading the Torah (OT) on my own, with new eyes and without the denominational bias that had blinded me for years. I longed for a like minded community, at least one that embrassed the Torah and that is how I ended up in Messianic Judaism. I privately rejected the Trinity and Yesha as G-d, but attended for the fellowship. Eventually, I left and attended some private home study groups of the Lost Ten Tribe variety, but here again this ran its course and I just did not fit. Although I had first been introduced the the term 'Noahide' about 10 years earlier in my personal studies, I did not become there were were actual Noahides out there until around 2001 via the internet search. I attended a Noahide conference in 2008 in Florida and that is when I made my personal declaration before a bet din.

I first discovered that the Torah is the truth. Following this, I learnt that there are two possible paths non-jews can take (to be a noahide or to convert). Conversion is not an option for me due to circumstances and thus I identify as a Noahide. The beauty of Torah and Jews continues to attract me.

The Xian faith ceased to make sense to me some years prior to finding the Noachide movement. I searched many avenues to G-d. I always only believed in one G-d and that he was represented by the G-d of the torah. I was seeking the best avenue to connect to the G-d I believed in and ultimately this was it.

Jewish identity.

\section{I prefer not to respond}

I was searching for truth and answers to religious questions. Finding the answers to these questions, the beauty of the Torah, the peace that the truth brings and the Joy of understanding G-D's purpose for our lives continues to attract me and fills my life with wonder, gratitude and contentment.

It's my life with Tora and I know it

The label was given to me because of my intense interest and discovery of Torah.

i prefer not to respond

I prefer not to respond

I am coming out of churchianity and I am learning the truth - wanting to follow Torah - all of it.

It is a starting point in my journey. Still getting the stench of idolarty off and out of me.

It is the truth of the One True God and I was not born to a Jewish mother so it works for me

Began to study Torah/Tanukh after finally hearing/discovering its TRUTH. 
I realized I no longer believed in the new testament teachings/Jesus, but still believed in the God of Israel. It wasn't God that I had doubts in, just the dogma of the church. So I threw the bathwater out, but kept the baby, so to speak.

india is the reason because noah lived in india.

I found a shortcoming in Jesus' golden rule: love your $\mathrm{G} \mathrm{d}$. I realized as a gentile I didn't know G d, so how could I love Him? I could only seek directions. Suddenly Jesus seemed inadequate. And a lil' while later I stumbled across the 'Children of Noah' on Reference.com while browsing the Maccabis in 2013.

I was formerly a pastor in a "charismatic" organization. As I studied the Torah, I moved first into Messianic circles and then began reading rabbinical writings such as Pirkei Avos. My studies exposed the fallacies in the Christian (especially the Messianic) doctrines. When I questioned those in Christian leadership on those matters, they had no answers. I was fortunate to be invited to a traditional Orthodox wedding in a strong Yeshiva community. Many of my questions were answered, as I was exposed to the Rabbinical teachings. I began the conversion journey, but family considerations were too great. I have never been more spiritually fulfilled (and confident of my "eternity") as I have since embracing Noahidism five years ago.

prefer not to respond

Went from catholic to atheist... Then studying the history of Israel got conviced of G.d's existence. Found that Jesus lacked many features of the messiah... Then found out about Noahides from Jewish litterature.

Mormons try to convert me, I befriended them and think they are lovely but do not understand their concept of Jesus. So I investigated Judaism and found that G-d is one. I am a non Jew who wishes to please G-d via Noahidism.

Saw the wholes in Christianity, sought out Former Christian in process of conversion and asked questions. What attracts me: My love for Hashem and to follow Him and His Commandments.

The fact that the Noachide laws were the first established laws of G-dd to mankind

$\mathrm{n} / \mathrm{a}$

I prefer not to respond

I prefer not to respond.

The Torah as revelation of G-d.

I believe I was a Noahide way before I knew that there was any such thing called Noahides .When I was a Christian I knew something wasn't right, it even says in the book of Acts, Christian bible, chapter 15 about the laws as the spark grew the more I searched the web for more information.

Achievements and unique history of jewish people 
I was Seventh Day Adventist 18 yrs $n$ already kept sabbath....I realized I did not know much bout Judaism and should know what Jesus had been taught $\mathrm{n}$ practiced . Changed my world.studied w vendyl Jones $n$ ariel bar tzadok for 8 yrs intensly. Esp kabbalah. I do integrative vibrational therapies..massage, Reiki medical chi gung $\mathrm{n}$ sound healing $\mathrm{w}$ tuning forks. God created w sound/frequencies....Jesus healed w sound and just being in his nrg field healed the woman touching his garment ......created matter,fish $\mathrm{n}$ bread....all kabbalah $\mathrm{n}$ quatum physics. All this has drawn me closer to the Divine Source!! I no longer feel limited to A belief SYSTEM....personal relationship w my creator. Many paths to top of mountain....depending on your own vibrational frequency you will be w those at same level....and beliefs that resonate $\mathrm{w}$ you. Not limiting god to any definition or parameters now....Blessings $n$ shalom! !!

I prefer not to respond.

How well it works with the world around me. It provides practical guidance and inspiration for all areas of my life - family, friends, work, play, etc.

I kept having recurrant dreams. The dreams had details in them I had no way of knowing. I started keeping a journal of the dreams and finally used the net to verify the reality of people in my dreams. They ended up being real.

I felt drawn and understood and could identify with Jewish teachings and knew somehow we were connected but did not know how to connect as I didn't find it easy to do this as I didn't physically know any Jewish people. eventually with the help of Hashem and daily prayer I 'came across' Chabad and AskNoah where I took a Noahide introductory course and connected with a Jewish Friend in Facebook whom I asked questions of to help me understand how and where we all 'are' - what I was looking for was a place I could sit comfortably from within myself and fit also within my physical existence, locally and globally too

By following the Noahide path, I can both obey the commands of my Creator and stay close to His Chosen People without becoming a Jew via conversion. I am accepted and taught by my local Jewish community as though I were a Jew. I look to the rabbis for my instruction and am welcome to participate in Jewish holidays. I feel at home with the Jews, but not able to pursue conversion at this point for varioius reasons. Being a Noahide is a perfect fit for where I am in my spiritual journey.

Because I long to get closer spiritually to Torah Truths

After leaving the church(christianity) I needed a frame of reference. This was persented by the Rabbi as an option, the other being a G-dfearer. I don't know if "attraction" is the correct word. G-d made me what I am. I am not Jewish! Then what other choice do I have as a Gentile. My belief is that if G-d wanted all people(nations) to be Jewish(Israel) then he would have made us all one nation - people. There is the option of conversation, for some that is the path. However, I do not see conversation as the path for everyone. In the Hebrew Bible we witness two trajectories for conversion to Israel's God, NOT ONE. 1) Ruth the Moabite (Your God will be my God, your people will be my people) and 2) Naaman the Syrian (Your God will be my God, but my people will still be my people). Years ago one of my teachers when asked why he did not convert stated, "Because HaShem Yisborach/G-d did not create me as a Jew. He created me as a Goy. Therefore, I have to get on with being the best Goy I can be, and you have to get on with being the best Jew YOU can be." And then there is the third option: What if in the future I find out I am one of the lost ten tribes? I guess I will have to rejoin the family!

It made sense to me, since I was not born a Jew, and did not feel the need to comply with all of the Jewish laws. 
The respect I get from Orthodox Rabbi's and they are willing to teach. I was invited to Israel for a Noahide convention which sealed my desire.

Since I was a teenager I never believed in any form of Christianity and wanted to see where they went wrong so I studied Judaism for years and identified as one.

I take grave offense at you separating the Catholic Church from Christianity. You obviously need to do more studies for your Master's Thesis, Pat. Christianity is a religion; Catholic and Protestant are denominational subcategories within it. I personally am a member of the Eastern Orthodox Church, and always will be, Noahide or not, and I'll bet you're not sure of how to categorize Orthodox Christians either, right?

consistent with my core beliefs

Clear, simple, ancient truth.

eu prefi

I discovered the lies I was told as a Christian

from nohaide I chosen to be jewish now! I wanted to be part of jewish people!

It appears to be Biblically sound and based on the Torah.

I realised that Christianity was a huge lie - a big con I recognised that Judaism was and is the original and only TRUTH

Since I as7 years old, I had a direct relationship to God. Was always puzzled as to Christianity saying, I needed an intermediary. When I was introduced to the 7 laws as my connection to Torah, To Hashem, and to Israel, It was like --that's who I am

I prefer not to respond

When I learned my true bloodline, and the so called new testament depending on what version you read seems edited. Jesus was not the messiah, or son of G-d.

First I discovered that Christianity was a lie. Noahides are HaShem's way of making a way for the rest of the world to connect to Him.

It has been His plan even before there were Jews. He provided a way for all mankind because He loves us. The Jews are His priests. They have more responsibility than the rest of us. That is why they are held to a higher standard. But it does not mean that He loves us less.

Through my Rabbi's teaching and other Jewish teachers.

When I understood Acts chapter 15 was talking about the Noahide laws... And when I realized that the Apostles were still Jewish and did not convert to what we would think of as Christianity.... I wanted to know how God was worshiped by non Jews before the Jews and non Jews were divided... I found my way thru Torah how to be the Ger who sits in the Synagogue and worships God in truth and but does not have to convert to Judaism in order to do it....

I felt is was where Hashem was leading me. I believe it is the correct path for gentiles.

I was raised Mormon, but the idea of one supreme G-d who is not identified with any particular human incarnation made the most sense to me. 
After finding out my previous belief systems was false, I wasn't sure where I was. I knew I was not a Jew and searched for a gentile who believed in what they did and did a google search found Noahide was what I really was. This began our journey. There is no other way to be besides conversion. There is only one truth and only One HaShem

I've always had questions about God that Christianity did not answer. I identify as a Noahide because I follow the God of Noah and the Jewish patriarchs/nation. Who is One, and will always be One.

GENESIS 9:27 A GER TZEDEK IS STILL A GER. CONVERSION IS AN UN-NECESSARY BURDON. JEREMIAH 31, MELCHI TZEDEK IS THE KEY FOR NON-SHEMITES. TEMPLE WORSHIP IS CHURCH WITH PRIESTLY INTERCESSION AND SACRIFICE. NOAHIDES BY-PASS MOST LEVITICAL LAW. THE TORAH GIVEN TO ABRAHAM FROM SHEM BEFORE EGYPT IS WHAT WE NEED TO SEARCH FOR. NOAHIDE TORAH IS ENOUGH FOR RIGHTIOUS GENTILES.

I prefer not to respond

I read the laws and understood by reading the bible that they were correct. They are undeniable.

Belief in God and the unity of God. I do not believe that God would be divided into parts or become flesh.

The "Truth" in HaShem's Word written by Moshe Rabneu.

I prefer not to respond.

There were Southern Baptist (like me) pastors who were converting. The last straw was asking Jews for Jesus about there response to the movement. Their response back was answering these questions "would be like handing a suicidal person a loaded gun". By this point in my life I already had had a heart-to-heart with God. He promises to move you and change you when need be. I knew I loved God the father but I was no longer a Christian. It took a few years to cling to the name Noachide because I kept getting booted out of the rooms and the lists, because why wording sounded to Christianese. Trust of outsiders and access to learning and changing was hard in the early years.

I left christianity because of the lies in the Christian Bible. Seeking truth lead me to a messianic form of christianity whereby they follow the torah and use the Hebrew names for NT bible figures. Finding out the lies are still present, I left that faith and tried to pursue Judaism. Upon talking to a rabbi, he encouraged me and my spouse that because we live in a remote area conversion would be impossible due to not being near a synagogue or having a rabbi near by. Noahide faith was the only option for us. After doing the research and overcoming the lies of christianity, we are happy learning about the Torah and serving the Gd of Israel in this manner. If something were to change in our location allowing us to convert to Judaism, we will pursue that avenue. Presently it is impossible.

After a lifelong search for the truth about the Creator, I finally found the Truth in Torah and the people of Israel. Realizing that I wasn't quite prepared to accept the "yoke" of Torah observance, I understood I could have a relationshio with the God of Israel via the Seven Laws.

I was studying the split between Christianity and Judaism, reading about Judaism and came across a book about Noahides, and thought that philosophy is mine. 
I don't like identifying as "Noahide" because every human on the face of the planet is a descendant of Noah. Aside from the Jews who have their separate, more elaborate covenant which includes rites and rituals, we all fall under the category of Noahide. The fact that I am observant of the sheva mitzvoth is a separate question. However I don't like it when people ask me, "well then how would you identify yourself?". The identifier exists for the sake of other people trying to put me into a box, not because it is a strong part of my identity, despite the fact that, yes, I do not IDENTIFY with the proliferate Xtianization of the Western world. 
I had a LDS (Mormon) childhood and a Protestant Christian adolescence and early adulthood. At age 26 (I'm only 27 right now in 2015, so this only began a few months ago), I was having life crises, and like any "good" Christian, I turned to the gospels and New Testament. My studies went well, and I was feeling more knowledgable and empowered about what I already "knew to be the truth" about "our Lord and Savior Jxxxx Cxxxxx". Then, I had a flash thought about things it says in the NT, and I was thinking "this is not a random man that showed up on scene, claiming to be Gxd in human form, with this new salvation program...he has very specific claims about who he is, and we know he is who is says he is because of prophecy that proves it". I realized that to be a great and knowledgable Christian, I should not just know the gospels in-and-out, but I should also know the prophecies. That way, I will be very knowledgeable and SURE that what I believe is absolutely true. To my shock and horror (at the time), I realized the prophecies did not indicate Jxxxx was "the one". Furthermore, I was learning that Christianity and Judaism are very different beliefs; I thought they were the exact same religion, in full agreement on every topic minus whether it was Jxxxx or someone else. At first, I wasn't able to psycologically accept that Jxxxx "wasn't real". I was recognizing that the "case for Jxxxx" wasn't looking good, but I was determined not to turn my back. It actually caused me to study prophecy more fervently, just to find "anything" that could validate the "case for Jxxxx". I was hoping perhaps messianic prophecy would be subjective, and I could sort of determine whether the evidence was substantial enough. The funny thing is, the more I studied to find evidence in favor of Christianity, the more I learned how wrong it was. Once I beat it dead, and realized Christianity is false, I did NOT "default" to "oh, then the Jews must be right" (as many would think I did). I felt so sad and traumatized that what I believed was absolutely true was completely and undeniably shattered. At that point, I realized I couldn't "just believe" anything anymore. I was thinking about how strongly Christians "KNOW that Jxxxx is", how sure an LDS testimony is (I KNOW the Book of Mormon is true, I KNOW Joseph Smith was a true prophet, etc), how strong a radial Muslim's belief is if he's willing to crash planes and kill innocent people, how about a monk or a nun who dedicated their lives to what they believe. Can ANYbody really say they have a monopoly on truth? I realized all these people are the same; we might all believe different things, but our level of sincere belief and dedication to our beliefs are the same. I realized you can't determine if a religion/belief system is true based on the followers "belief quantity level" (even if you could objectively measure it), nor could you base it off who has more followers. I went through a long period of believing....nothing...I guess. I was sort of on this quest for truth, recognizing I didnt have any method to determine truth. Anything I could read, find out, or experience, couldnt really be more "true" than what someone else experienced. I was reading and reading about all religions. Just learning, just gaining knowledge. My fiance was getting concerned....he said "are you just going to read about every religion and at the end just pick one?", a valid question. I began studying the origins of religions. How does a religion begin? There's always a starting point. I realized Paul of Tarsus had a life-changing experience, and then he traveled and taught and it changed lives. Joseph Smith had an experience, Mohummad, etc. And then there was the Jewish people. Jews today celebrate Passover and Sukkot (related holidays, 40 days apart, the story of how they left slavery in Egypt and how they received the Torah at Mt Sinai). With the exception of converts, Jews celebrate it based on what their parents told them, and then on what their parents told them, and what their parents told them, etc. The first Jews were there when they heard Gxd speak, and wouldve known the entire story was a sham if it didnt happen actually to them. Their history isn't based on one persons "claim" that they spoke to something divine (Gxd or an angel), and this applies to even Moses because all the Jews there did not just take Moses' word for it, they heard Gxd for themselves. Again, I this is just something "I believe", but from my point of view, its the most substancial evidence that I have found. There are people today (the Jewish people), and over generations have been through so much, and it would be so much easier to abandon Judaism than to hold on. I see that as substancial evidence that this is something that actually happened. I guess there is also the circumstancial argument, "Why have 
I started wondering "Why don't the Jews accept the New Testament", found an article about it, and was convinced by it.

I realized I really suck at keeping Shabbos. I wanted to abstain from desecrating the Name.

Still see the Old Testament as potentially inspired.

It gave a moral structure to my life

I prefer not to respond

I started at a very young age thinking there has to be more to G-d than getting people to except jesus it and getting people to church. That is what was stressed most. So i started looking into why does it say in the NT to be saved you have to go through jesus and in to OT it would say G$\mathrm{d}$ alone can save. The three in one thing was always a question to me I was like G-d is ONE not three. and all men must come through jesus it would say and in another place it said if you be circumcised christ will not benefit you. I was like What??? so many questions that none of the xtans could answer. like how did jesus get anointed? there wasn't and anointing oil in his day. and i get some off the wall answer that is spiritualized hog wash, when in the Torah G-d said just how it was to be done. I said someone has to be wrong and it cant be G-d so I starting praying to Hashem to show me the truth for very long time years $\mathrm{i}$ would ask for truth. Then $\mathrm{i}$ met a young lady and married her and she then told me about her mom going to hear a man named Vendyl Jones every week speak about the Torah and some digs he had done in Israel, would i like to go hear him. I was like Oh yeah I do. So Vendyl and I grew together into the truth. B'H Blessing be from Hashem For sure.

I found torah \& Hashen to be truth, and left the lies I'd been taught. I want to convert but it is not possible. So Noahide, I suppose.

I was and I am still attracted by the legal aspects, social justice. That's what our world needs.

"Noahidism" is not a thing. We're not in the business of creating a new religion. We're religionless. I believe in the teachings of Judaism.

I prefer not to respond

I was looking for the truth and I feel I found it. I was praying pretty hard to the G-d of Abraham, Issac and Jacob. I felt that He led me to this path. I'm staying on it.

Allways believe in Torah. The xristianism is not real.

the truth

Noahides are non-jews who believe in Torah, it's a first step till we decide converting to judaism, or a conciliation between being non jew and being fascinated by judaism/feeling jew.

The answer for both questions is the same. After searching for a while, I asked G-d for a religion that could help me to be a good person in His eyes, a couple of days later I found out about Noahism and I felt and thought it was me (consistent with my own journey with Him and my trust in the Jewish People).

I realised how true was the Torah of Israël and I wanted day after day to know more and more wow this is easy one. the truth of torah speaks for itself and $i$ was amazed and still am at the breath and depth of the truth torah holds. 
after an orthodox rabbi that i follow mention in his lecture that there is a way for a gentile to be rightheous and to have share in the world to come.

My parents were exposed to Torah and the Noahide path in a rural church in Georgia in the early 80s. My father came from an atheist background, my mother was a devout Southern Baptist. I was around four years old when they committed to the path and started seeking out guidance and information. My father even attended the Kollel in Atlanta for a time. I only have one recollection of a family "Christmas", and even then it was clearly a holiday they were at odds with, reassuring us that the gifts were from them. Growing up, my parents told me and my three siblings that the choice was ours regarding our religious path. They were there for questions, and we were exposed to a lot, but they weren't pushy. Despite growing up in the Bible Belt, I held firm to the notion of the truth of the Torah, even in the face of bullying and drastic conversion tactics (my grandmother telling me I was going to hell without Jesus, or taking us kids to Church against my parents' wishes). In truth, rural Southern Baptist congregations aren't the best way to get a child interested in Christianity. My early attraction to the Noahide path had as much to do with my distrust of Christianity as it did with my love of Torah. But I have always been an avid reader, and I read Torah and asked questions. I always identified as Noahide, though, as far back as my memory stretches. I respected my parents and their conviction, and despite not knowing fully what I was getting into, I trusted their instincts on the matter. As such, I always felt a bit of guilt knowing that I was "no better" than anyone else who takes on a spiritual path based on their happenstance. I worked to make up for that by coming to my own conclusions, clouded as they might be by my upbringing. I feel confident in my path now.

I never found Torah to demand anything about belief or blind acceptance, only the full use of one's mind and physical-spiritual faculties, and not just for one's self, but for all humanity, and indeed, for all life.

Through study of the Tanach with the help of Orthodox Jews and compareing it to the Christian Bible and finding out that Jesus is not what the Christian Bible claims him to be. There is only one G-d and He does not share His equality with anyone or any thing.

I wanted to attend to any Judaism Synagogue but it is too far from our location. and as I seek over the net of Jews in Cebu in facebook, I have this Noahide org in Cebu.

Dreams, Visions and G-d's Will. Rational thoughts.

i prefer not to respond

Came out of Xtianity to "Messianic Judaism." Discovered Yoshke could not biologically be the Messia. Began pursuing conversion to Orthodox Judaism. Discovered SMBN, and felt that if I acknowledge it as Torah Truth, I should embrace and experience it before further pursuing geirus.

The Rebbe O.S.M. was writing so well and videos of him attracted me and moreover, as a student I was redeemed of very bad illnesses that are spiritual. Even if there's a residual amount and I'm under a doctors care. When I wrote to Ask The Rabbi of Chabad.org I always would put at the end "from an aspiring Noahide." One time I was directly asked why not think of myself as one and consider myself one? Rabbi at the Lubavitch Center really helped me get to a healthy place and suggested to me I google Noah which I did. I found Chabad.org

I prefer not to respond

I prefer not to respond 
Its simplicity, compared to the varieties of Christianity I've experienced .

I began to identify myself as a Noahide when I had made the decision not to continue my (orthodox) conversion, although I may convert in the future. I am proud to be a Noahide. It's Gd's instructions for Nonjews. It's not as easy as one might imagine. I am attracted to it because it is the absolute truth.

After leaving the church we spent many years in the messianic community. We were drawn to orthodox teachings and listened to orthodox rabbis regularly. This led to us learning what messianic Judaism really is: a method to convert Jews. We left that group and began learning strictly from Orthodox Jewish Rabbis. Primarily, Rabbi Tovia Singer is the one who opened my eyes and caused my love for Torah Judaism to blossom. I am now Bnai Noach and proud of it.

I wanted to know why G-D create so many religions.

I was raised in a 'mixed' marriage and identified as Jewish. As I become more observant I learned I was not accepted as a Jew by the Orthodox despite having never practiced another religion. I explored conversion and Noachidism under an Orthodox rabbi and embraced Noachidism instead.

For non-Jews from birth, fulfilling the seven Noahide laws is the proper manner of serving $\mathrm{HKBH}$ as commanded at Mt. Sinai through the hand of Moses to all the world and as faithfully transmitted in each generation to the non-Jews by the Rabbis of Israel.

Because it is my G-d calling to me and no other form of religion holds true to Him like Judaism and the Torah

It makes more sense to me.

It was the most logical approach to understanding "religion."

It makes sense..judisim makes sense..nothing else does

That G-d made a path for Non-Jews in partner with Jews for the redemption of the world. It's core principles which is the Sheva Mitzvot \& they are reasonable and rational.

I prefer not to respond.

I want true worship of the One true G_d. I cannot prove Jewish genes. So I am content with Noahidism.

Proper life style for any non-Jewish person who follows the one true G-d. Obviously the true faith G-d intended for the masses. Simple, easy to follow laws. No forcing others to your faith or "their going to hell".

Torah study

I fitted into the description, and being called a Noahide separated me from my past self..somehow revive me spirituly..the UNITY of G-d,Torah,Talmud,Judaism in general never fail to attract me..I must admit sometimes I listen or read (musars..etc) not meant for noahide..but I'm aware to not cross the line or create a religion for myslef..

At the point I realized it will be almost impossible for me to convert in my country.

I did not want to worship a man-god. And Christianity has a deep history of hatred, theft, murder, oppression, racism and slavery. 
monotheism

Because the Torah and Torah Judaism were truth to me and being noahidewas what I was madequate aware of as a non jew. The truth of Torah continues to attract me.

I learned that I had been lied to. I went to Chabad and someone told me about the Noahide. I looked it up and found out what it was all about and that is is biblical. I like it because it is a part of Judaism and i know the Jew are the only ones who have things right. This is from HaShem.

It is Biblical and it relates directly to teachings in the book of Acts and Galatians which are authentic teachings but have been corrupted by Christian interpreters and misunderstood by both Christians and Jews.

The truth came out as I studied the new testament. Christianity only makes sense if you've heard nothing else. The teachings of the Jews makes sense and is beautiful not terrifying like Christianity. So many lies held together by lack of knowledge.

I don't think on Noahidism as a religion. I think like a lifestyle. I share views with Judaism concerning to G.d and the moral duties of the mankind. That's the reason I feel atracted by it: because it has a practical and moral framework in which we can have a connection with the Divinity without a religion. Only keeping ethical and moral laws. Besides, I conceive G-d as an absolute Unity, as Judaism does and through it, I can understand better the spiritual functioning of me as a person and the relationship between Israel and the nations in those terms.

It is the original and only valid set of instruction made by the Creator for non-jewish people.

as a real jew but came in a gental form..so i want to convert to judaism

I identify with the jewish people and I am a truth seeker....who better to learn truth from than the keepers of Torah.

It is s stepping stone, for me, to full conversion to Torah Judaism. My current situation does not allow me to convert.

Personal awakening

I had to accept being Noahide rather than converting because my husband is a Christian. At least being Noahide I can practice Judaism and be associated to Hashem and his people.

"I prefer not to respond."

As part of the beginning of my intent to convert to orthodox Judaism. That is generally how one begins the process.

$\mathrm{i}$ believe in the Torah of Israel, $\mathrm{i}$ think judaism is the truth, so for a non Jew, $\mathrm{i}$ have to respect the seven law of Noahism.

I realy like the teaching of many rabbi, they have a political view, and a spirutual view, that $\mathrm{i}$

consider as true.

And i was always attracted by Israel.

$\mathrm{i}$ am interessed on Noahism because $\mathrm{i}$ am interessed on Judaism.

Being a Noahide makes sense to me. It is where my soul is happy. It is my Ah-ha place. 
I left Christianity as a result of my theological studies at an evangelical christian university, but still felt the need to connect a religious community. Judaic thought provided a more philosophically rational view of a supernatural God.

Leaving xtianity resulted in quest for truth and authenticity. This lead to Torah and as nonhalachically Jewish defaulted to Noahide. This ended in emptiness too until I learned about Ger from Rabbi David Katz. I don't consider myself Noahide but rather a Ger

I belive in Revelation in Sinai. I belive that Istael in a holy nation. I belive that Torah is the word of God. I belive that Oral Torah preserved and developed by Jewish rabbis is the part of Sinaic Revelation. Also I belive that Jusasim is the only monotheism in real philosophic and theologic sense. I can't be a Jew now, I hope I will deserve to be in future, so now I'm trying to be a decent human being, a Noahide, but - in accordance with what Torah says on this issue.

These are the divine laws G-d intended for me. The opportunity to serve my King in Heaven through Tikkun Olam.

It rang true and replaced my faith in what I had begun to believe was a lie.

Through interaction with online forums and websites, I came to realize that Judaism was still a living religion.This created an anomaly with my Christian understanding that forced me to dig further into the Bible.

$\mathrm{i}$ believe TORAH is the foundation to Judaism but relates to every person

Once I understood that there were non-Jews involved with Hashem, I knew there was a place for mankind that did not involve conversion.

I realised that the Orthodox Jewish ideas of Christianity being idolatry and ignoring real Judaism were important to consider. Then I found that Christianity can't match the high caution in Torah about these issues. I see great wisdom and potentially also real revelation in Judaism's approach to and experience of worship. I tried hard to prove Christoanity but in the end it was morally impossible to stay in it.

I wanted to find out why Jews didn't believe in Jesus. What I read convinced me that they were correct. Being a Noahide is a way for a non-Jew to identify as a believer in God.

I am a patrilineal Jew, looking for my way in Noachidism or liberal Judaism. Noachidism feels not good as I am not a stranger while Judaism is complicated with the rabbi.

After rejecting JC I saw only 2 options 1) to convert or 2)the Noahide path.

Once I came to believe that xtianity was conceptually unsustainable in Jewish thought (and began to try to become a Jew), I no longer identified as xtian but I could not yet identify as Jewish. Then I became aware of Bnei Noachism and was able to identify that as my position (wether temporarily of otherwise).

No one else.would except me.

I am still a christian but follow noahidism. I devote my life to Christ and I am a pastor but I affirm the noahide laws and follow them. I was going to convert to Judaism but found myself in need of the loving forgiveness of Christ and stepped back into Christianity. I prefer to call myself a messianic gentile.

It's complicated. 
I began to identify myself as a noahide because it's the only thing that's ever made sense the belief in the one true God is what keeps me attracted to it

I prefer not to respond

It is the covenant of G-d I am under being a non-Jew.

I studied it out in the Torah. What attracted me to it was that I was unable to disprove the Torah and therefore feel I am living the way God said Mankind should live.

It seemed closest to the "Truth" that I was trying to find, and seemed to most resonate with the values I held. It also seemed closest to Orthodox Judaism, which seemed to have the most answers to my questions about G-D.

I identified as Noahide because I believed in and continue to know there is One God, the God taught by the Jews. At the same time, I have not become a

Jew, and so I do not want to mislead anyone as being a member of the nation of Israel, as their role in the world is distinct from ours. I remain one among the Nations, Gentile, or Ben Noach. At the same time, just because I am not a Jew, I do not want to be mistaken as one of the other Gentiles who follow other paths (i.e. Christian, Muslims, one of the other religions, secularist/ atheist). A Gentile who walks the path of justice, i.e. Noahide Law, according to Torath Mosheh is not a Jew, but neither is he an idolater nor a denier of God. He lives his life according what is defined in the Torah (Written and Oral) as good and evil, forbidden and permitted, and what is generally expected for all humanity by the Creator Whom he accepts as the God of Israel and God of all creation, Master of the Universe.

Initally, the path of the righteous Gentile attracted me because it is easier to observe that path than to observe the path of holiness for Israel. I am drawn to this path still for the same reason; but in for solidarity (i.e. not abandoning fellow Noahides who remain few and far in between, though growing in number); and the need for teachers to whom fellow Gentiles can relate; and to increase the number of such God-Fearers through teaching, marriage and family, and building communities - to increase genuine justice and goodness among the nations according to the Torah definition of these laws for all humanity.

I believe that the Torah is truth, and according to the Torah this is the righteous way of life for Non-Jews.

I had abandoned Christianity, but not God. Seeking to understand God better, I learned from Jewish sources, in which I found much deep wisdom and compassion, but was conflicted since I was not Jewish. Finding the Noahide identity solved that conflict. What continues to attract me is the solid universal teachings of Judaism.

It is the basic moral code for all humanity. It has a flexibility to it.

After beginning to see a lot of things wrong Christianity I wanted the truth and searched with all my heart and soul, that's how I became to love Hashem, the Jewish people and His Torah (according to the Noahide Laws).

Noahidism is absolutely incorrect and would be considered a false religion. Following the Noahide laws just like a ger toshav did is part of Torah. No need for a new religion. In fact, the very idea that a non Jew create a new religion goes against Torah. It is said that since I can't use the word Judaism I should be labeled as a new religion. I follow the very same Torah and laws the Jews follow, the Torah. 
is nice

It all made sense after reading and learning the Torah

To help others. It's initially basic.

I could no longer accept the tenents of christianity because of the distortions of the writings of the Torah and the prophets.

Through a mystical experience I became aware of the truth of the Jewish (Written and Oral) Torah, and since the Torah commands this on the Non-Jews, I'm a practicing Noahide.

Although I was raised a x-tian, I always thought something was incorrect. I studied Judaism before discovering Noahidism. Once I found about the Noahides, I knew that was the correct path for me. Once my mother passes away, I may consider converting. I do not consider conversion now out of honor for my mom.

After independently studying the Bible, I began the move from traditional Christianity. After a brief tour (about 3 years) in the Messianic Hebrew Roots movement, JC was left behind for good. Since I did not live near a Jewish Community, being a Noahide was what a Non-Jew is if they uphold the Torah.

When I realized I wanted to be a Jew but not possible where I live. I realized I do keep the 7 Noahide Laws and that I can love Hashem even as a Noahide and keep his commands.

Q13 - How far away from a Jewish community (that has a shul/synagogue) do you live?

\begin{tabular}{|l|r|r|}
\hline $\mathbf{0 - 1 0}$ miles & 66 & $31.73 \%$ \\
\hline $\mathbf{1 0 - 2 0}$ miles & 29 & $13.94 \%$ \\
\hline $\mathbf{2 0 - 6 0}$ miles & 38 & $18.27 \%$ \\
\hline $\mathbf{6 0}+$ miles & 36 & $17.31 \%$ \\
\hline I have sought but have not found a Jewish community near me & 16 & $7.69 \%$ \\
\hline I have not sought a Jewish community near me, but I would like to & 8 & $3.85 \%$ \\
\hline I have not sought a Jewish community near me, but it is not important to me & 10 & $4.81 \%$ \\
\hline I prefer not to respond & 5 & $2.40 \%$ \\
\hline Total & 208 & $100 \%$ \\
\hline
\end{tabular}


Q14 - Do you have a relationship with this Jewish community?

\begin{tabular}{|l|r|r|}
\hline I participate in the community & 48 & $36.64 \%$ \\
\hline I have attempted to participate in the community, but I was not permitted & 9 & $6.87 \%$ \\
\hline I have not attempted to participate in the community, but I am interested & 39 & $29.77 \%$ \\
\hline I have not attempted to participate in the community, but I am not interested & 13 & $9.92 \%$ \\
\hline I prefer not to respond & 22 & $16.79 \%$ \\
\hline Total & 131 & $100 \%$ \\
\hline
\end{tabular}


Q15A - How often do you partake in activities with this Jewish community?292

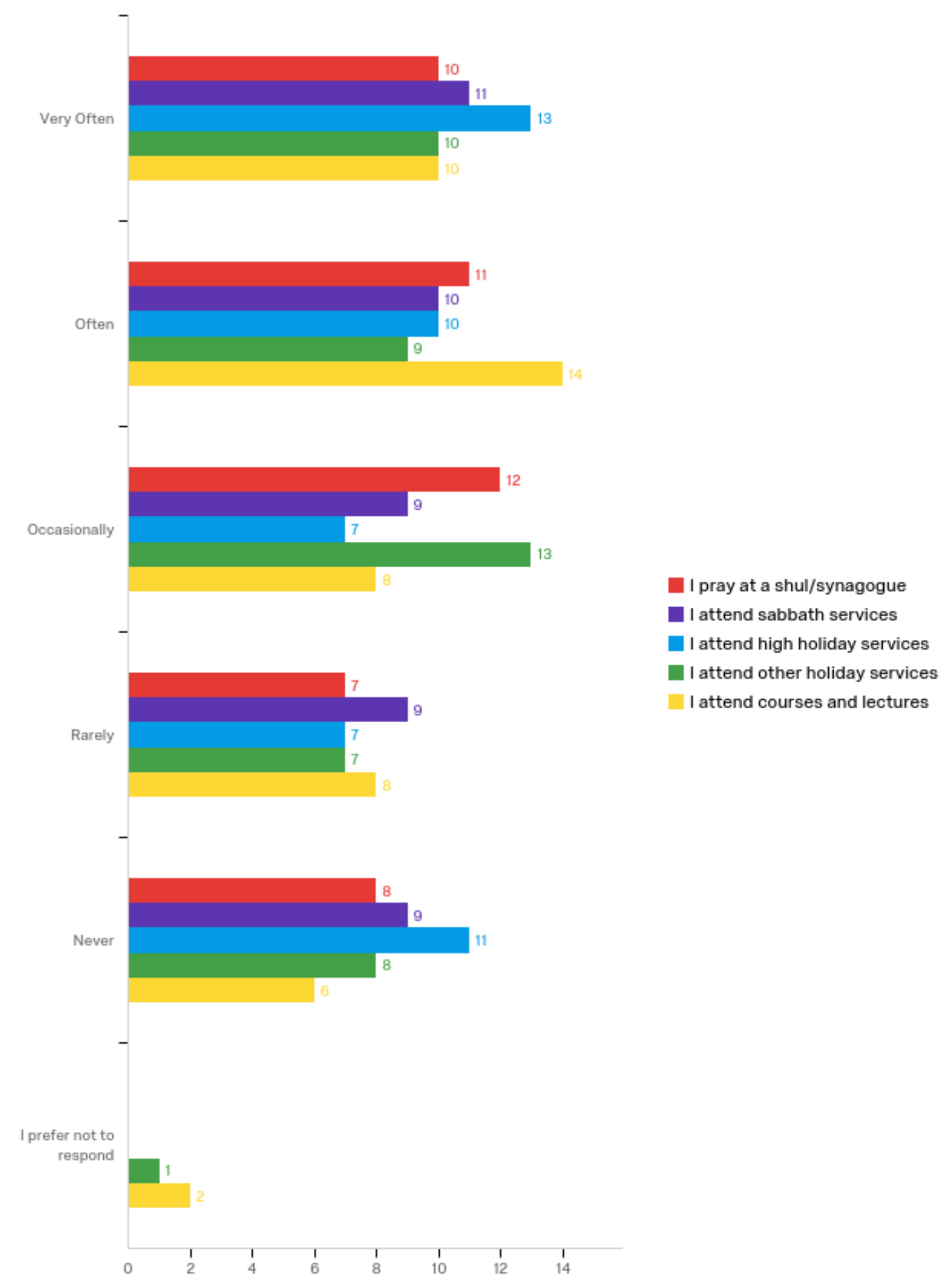

29248 respondents answered this question. 
Q15B - What kind activities would you be interested in if you were to have access to a Jewish community? Select all that apply

\begin{tabular}{|l|r|r|}
\hline Praying at shul/synagogue & 33 & $68.75 \%$ \\
\hline Attending sabbath services & 37 & $77.08 \%$ \\
\hline Attending high holiday services & 32 & $66.67 \%$ \\
\hline Attending other holiday services & 30 & $62.50 \%$ \\
\hline Attending courses and lectures & 43 & $89.58 \%$ \\
\hline I prefer not to respond & 1 & $2.08 \%$ \\
\hline Total & 48 & N/A \\
\hline
\end{tabular}

Q16 - In general, how are Judaism and/or the state of Israel received in the region wherein you live? ${ }^{293}$

\begin{tabular}{|l|r|r|r|r|r|}
\hline \multicolumn{1}{|c|}{ Well } & & Indifferently & Not well & I do not know & $\begin{array}{c}\text { I prefer not } \\
\text { to respond }\end{array}$ \\
\hline Judaism & 60 & 73 & 24 & 42 & 4 \\
\hline The state of Israel & 71 & 47 & 31 & 47 & 7 \\
\hline
\end{tabular}

\begin{tabular}{|l|r|r|r|r|r|}
\hline In percentage points & \multicolumn{1}{l}{ Well } & Indifferently & Not well & I do not know & $\begin{array}{c}\text { I prefer not } \\
\text { to respond }\end{array}$ \\
\hline Judaism & $29.56 \%$ & $35.96 \%$ & $11.82 \%$ & $20.69 \%$ & $1.97 \%$ \\
\hline The state of Israel & $34.98 \%$ & $23.15 \%$ & $15.27 \%$ & $23.15 \%$ & $3.45 \%$ \\
\hline
\end{tabular}

293203 respondents answered this question. 
Q17 - How many texts or online books have your read concerning Noahidism or the laws of Noah?

\begin{tabular}{|l|r|r|}
\hline None & 9 & $4.43 \%$ \\
\hline $\mathbf{1 - 3}$ & 57 & $28.08 \%$ \\
\hline $\mathbf{4 - 6}$ & 46 & $22.66 \%$ \\
\hline $\mathbf{7 - 1 5}$ & 33 & $16.26 \%$ \\
\hline $\mathbf{1 5}+$ & 49 & $24.14 \%$ \\
\hline I prefer not to respond & 9 & $4.43 \%$ \\
\hline Total & 203 & $100 \%$ \\
\hline
\end{tabular}

Q18 - To any extent, do you participate in any Noahide communities either online or nononline?

\begin{tabular}{|l|r|r|}
\hline Online & 139 & $68.47 \%$ \\
\hline Non-online & 48 & $23.65 \%$ \\
\hline I have tried but have not been able to participate in any & 15 & $7.39 \%$ \\
\hline I have not attempted to participate in any, but I am interested & 25 & $12.32 \%$ \\
\hline I have not attempted to participate in any, but I am not interested & 5 & $2.46 \%$ \\
\hline I prefer not to respond & 12 & $5.91 \%$ \\
\hline Total & 203 & $100 \%$ \\
\hline
\end{tabular}


Q19 - For how long have you participated or have tried to participate in these Noahide communities? ${ }^{294}$

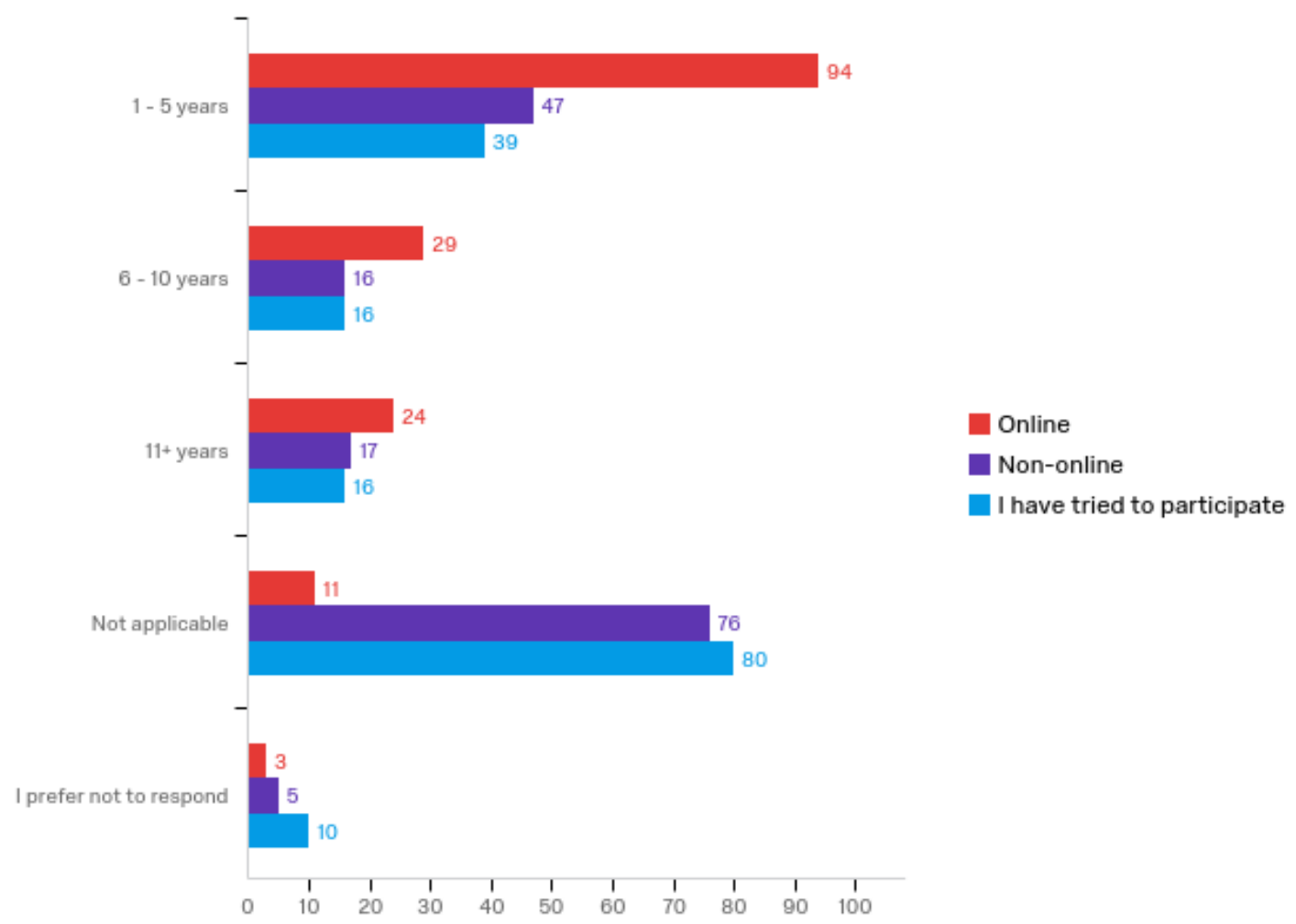

Q20 - Have you ever studied either the Jewish or popular Kaballah?

\begin{tabular}{|l|r|r|}
\hline I am studying now & 77 & $38.50 \%$ \\
\hline I did in the past & 35 & $17.50 \%$ \\
\hline I have never, but I am interested & 32 & $16.00 \%$ \\
\hline I have never, but I am not interested & 43 & $21.50 \%$ \\
\hline I prefer not to respond & 13 & $6.50 \%$ \\
\hline Total & 200 & $100 \%$ \\
\hline
\end{tabular}

294161 respondents answered this question. 
Q21 - How do feel about the spiritual, legal, and liturgical resources (texts, places of worship, courses, etc.) available to Noahides? 295

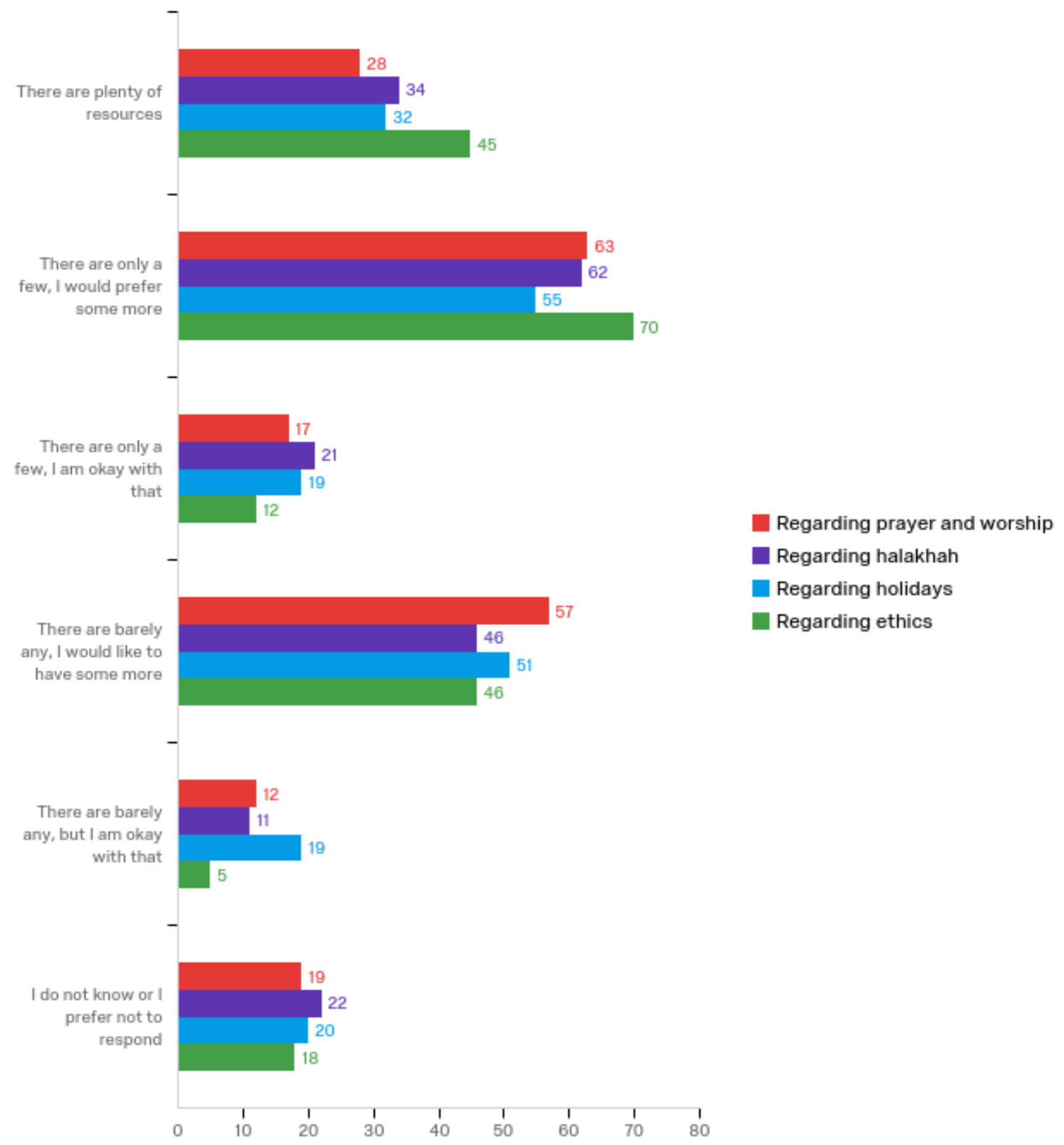

295196 respondents answered this question. 
Q22 - How often do you pray?

\begin{tabular}{|l|r|r|}
\hline Never & 0 & $0.00 \%$ \\
\hline Less than once a month & 7 & $3.57 \%$ \\
\hline Once a month & 0 & $0.00 \%$ \\
\hline $\mathbf{2 - 3}$ times a month & 5 & $2.55 \%$ \\
\hline Once a week & 5 & $2.55 \%$ \\
\hline 2-3 times a week & 24 & $12.24 \%$ \\
\hline Daily & 139 & $70.92 \%$ \\
\hline I prefer not to respond & 16 & $8.16 \%$ \\
\hline Total & 196 & $100 \%$ \\
\hline
\end{tabular}

Q23 - How often do you read religious texts?

\begin{tabular}{|l|r|r|}
\hline Never & 0 & $0.00 \%$ \\
\hline Less than once a month & 3 & $1.55 \%$ \\
\hline Once a month & 1 & $0.52 \%$ \\
\hline 2-3 times a month & 9 & $4.66 \%$ \\
\hline Once a week & 11 & $5.70 \%$ \\
\hline 2-3 times a week & 47 & $24.35 \%$ \\
\hline Daily & 111 & $57.51 \%$ \\
\hline I prefer not to respond & 11 & $5.70 \%$ \\
\hline Total & 193 & $100 \%$ \\
\hline
\end{tabular}


Q24 - How often do you have contact with Noahides other than those in your household? 296

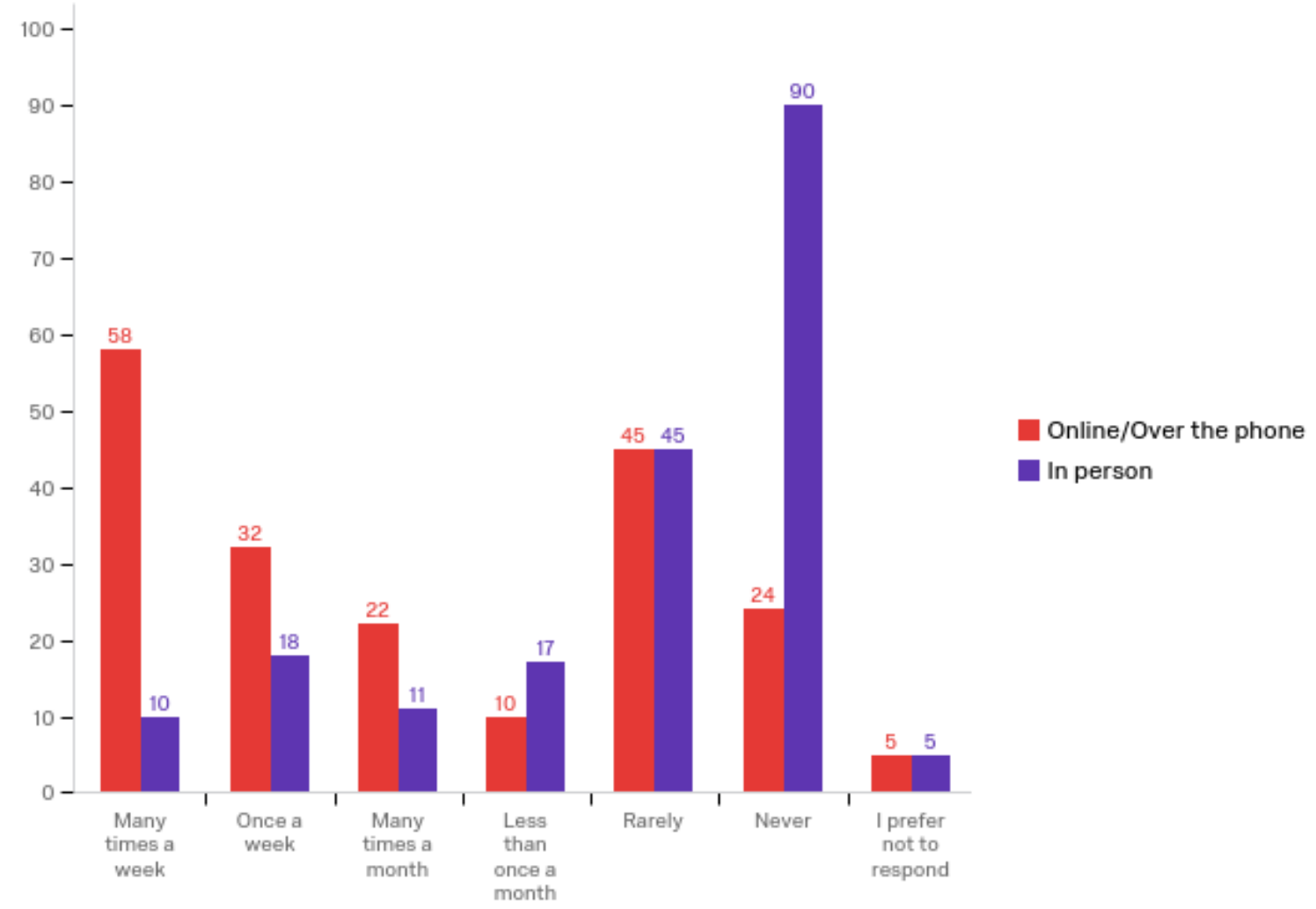

296196 respondents answered this question. 
Q25 - In your experience, how is Noahidism received by your friends, family, and strangers? ${ }^{297}$

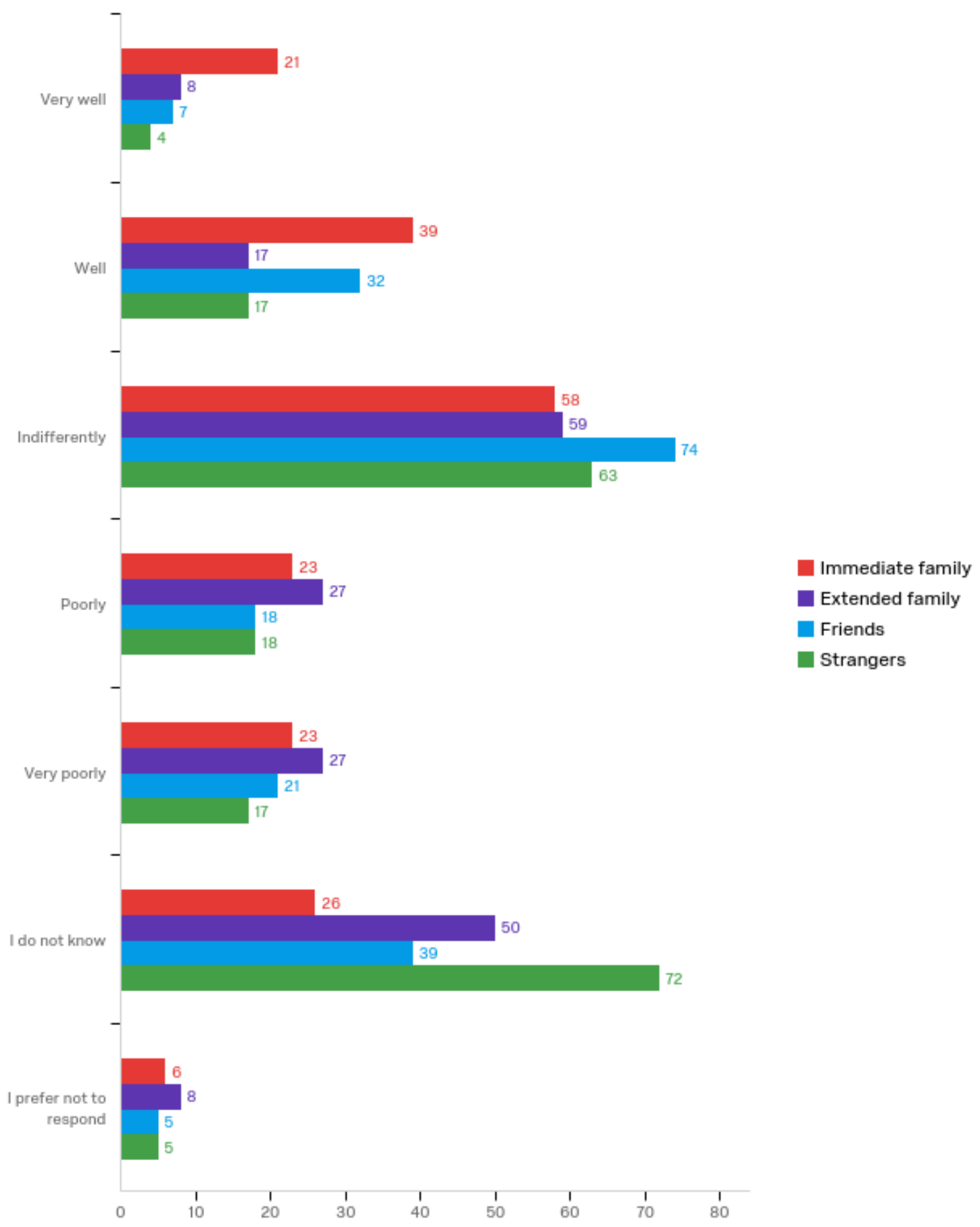

${ }^{297} 196$ respondents answered this question. 
Q26 - Which country are you currently located in?

\begin{tabular}{|c|c|c|}
\hline I prefer not to respond & 6 & $3.06 \%$ \\
\hline Australia & 3 & $1.53 \%$ \\
\hline Brazil & 3 & $1.53 \%$ \\
\hline Bulgaria & 1 & $0.51 \%$ \\
\hline Canada & 8 & $4.08 \%$ \\
\hline Chile & 1 & $0.51 \%$ \\
\hline Finland & 1 & $0.51 \%$ \\
\hline France & 3 & $1.53 \%$ \\
\hline Germany & 1 & $0.51 \%$ \\
\hline Ghana & 1 & $0.51 \%$ \\
\hline India & 3 & $1.53 \%$ \\
\hline Indonesia & 1 & $0.51 \%$ \\
\hline Italy & 2 & $1.02 \%$ \\
\hline Kenya & 1 & $0.51 \%$ \\
\hline Malaysia & 1 & $0.51 \%$ \\
\hline Malta & 1 & $0.51 \%$ \\
\hline Mexico & 1 & $0.51 \%$ \\
\hline Norway & 2 & $1.02 \%$ \\
\hline Philippines & 8 & $4.08 \%$ \\
\hline Poland & 2 & $1.02 \%$ \\
\hline Portugal & 1 & $0.51 \%$ \\
\hline Romania & 1 & $0.51 \%$ \\
\hline Russian Federation & 1 & $0.51 \%$ \\
\hline Saudi Arabia & 1 & $0.51 \%$ \\
\hline Singapore & 1 & $0.51 \%$ \\
\hline South Africa & 2 & $1.02 \%$ \\
\hline Spain & 1 & $0.51 \%$ \\
\hline
\end{tabular}




\begin{tabular}{|l|r|r|}
\hline Switzerland & 2 & $1.02 \%$ \\
\hline Taiwan & 1 & $0.51 \%$ \\
\hline United Kingdom & 6 & $3.06 \%$ \\
\hline United States & 129 & $65.82 \%$ \\
\hline Total & 196 & $100 \%$ \\
\hline
\end{tabular}

Q27 - Not including yourself, how many people belong to your household? How many of your household members consider themselves Noahides? ${ }^{298}$

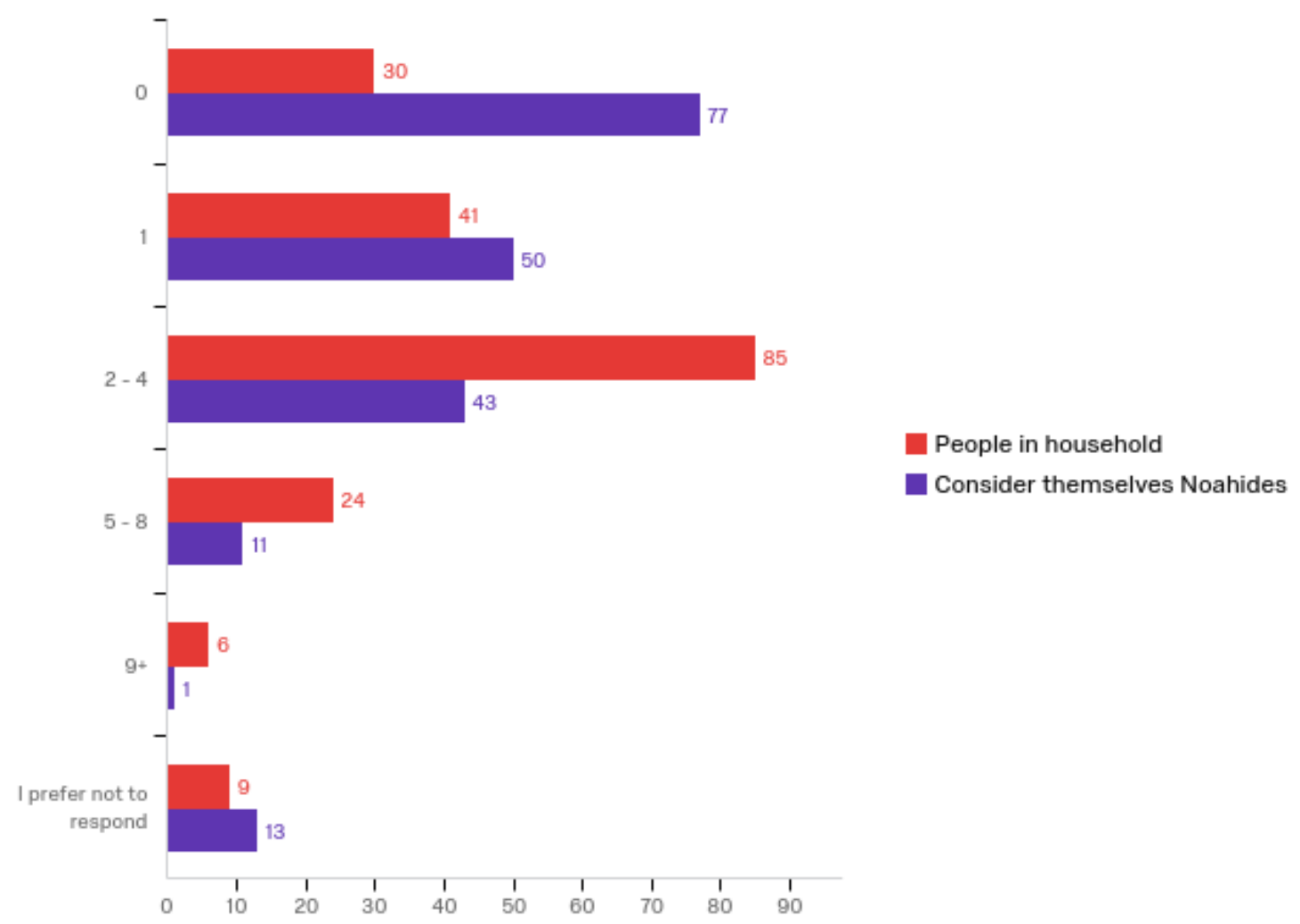

298195 respondents answered this question. 
Q28 - What is your age?

\begin{tabular}{|l|r|r|}
\hline $\mathbf{5}$ - 12 & 0 & $0 \%$ \\
\hline $\mathbf{1 3}$ - 16 & 1 & $0.51 \%$ \\
\hline $\mathbf{1 7}$ - 21 & 8 & $4.1 \%$ \\
\hline $\mathbf{2 2}$ - 30 & 24 & $12.31 \%$ \\
\hline $\mathbf{3 1}$ - 50 & 75 & $38.46 \%$ \\
\hline $\mathbf{5 0}+$ & 84 & $43.08 \%$ \\
\hline I prefer not to respond & 3 & $1.54 \%$ \\
\hline Total & 195 & $100 \%$ \\
\hline
\end{tabular}

Q29 - What is your household's average income in your native currency?

\begin{tabular}{|l|r|r|}
\hline $\mathbf{0}-\mathbf{2 0 , 0 0 0}$ & 29 & $14.87 \%$ \\
\hline $\mathbf{2 0 , 0 0 1}-\mathbf{4 0 , 0 0 0}$ & 45 & $23.08 \%$ \\
\hline $\mathbf{4 0 , 0 0 1} \mathbf{- ~ 6 0 , 0 0 0}$ & 25 & $12.82 \%$ \\
\hline $\mathbf{6 0 , 0 0 0}-\mathbf{1 0 0 , 0 0 0}$ & 32 & $16.41 \%$ \\
\hline $\mathbf{1 0 0 , 0 0 1}+$ & 20 & $10.26 \%$ \\
\hline I prefer not to respond & 44 & $22.56 \%$ \\
\hline Total & 195 & $100 \%$ \\
\hline
\end{tabular}

Q30 - What is your name? If you prefer not to respond, please write "I prefer not to respond."

Responses to this question are not being revealed due to IRB-FIU policy. 
Q31 - Please feel free to write any other information regarding yourself and/or your experiences with Judaism or Noahidism. We are greatly interested in the daily lives of Noahides and the issues that the Noahide community is facing at present. If you prefer not to respond, please write "I prefer not to respond."

Please feel free to write any other information regarding yourself and/or $\mathrm{y} \ldots$

I support the existence of the state of Israel due to public statements from the High Priesthood at Gerizim.

I do not support building temples, either at Gerizim or at Zion.

I've read so much but cannot get a handle on what is right. Are we allowed to study Torah? The sabbath is only for Jews, where does this leave us? I have way more questions than answers.

i miss church. miss having friends and fellowship that centers around my spiritual beliefs. that is the one thing i don't care for with noahidism....the lack of real life contact with others of like faith.

Christians treat Noahides just like Jews in my area -- with great disdain.

I've attended Kabbalah and Parshai classes at a Jewish Renewal center. They seemed fairly inviting to a convert. I've since studied a lot, Torah, the Rabbis, etc at chabad.org. For a while I thought of converting. I finally understood that I wasn't part of the tribe, or becoming part of it. Knowing that a convert should follow all Halacha is a deterent as well. I spoke to a Rabbi at the Denver Chabad House about attending, but feeling like an outsider I havn't followed up. I have experienced that my heart is a little softer.

I prefer not to respond

I prefer not to respond.

I prefer not to respond.

Need more rabbis to understand our religious needs, we almost need our own "rabbis".

In the UK there is very little activity and communication amongst Noahides. Very little help from Rabbis too. People just don't seem that interested in meeting up and talking to each other. 
I love Torah and have had a touch-and-go relationship with the seven Noachian halachot (most having given me zero grief apart from the one regarding avodah z'rah).

As it currently stands, I have brought myself back into the realm of Noachide observance with HaSh-m's assistance and permission. I take on the additional (for goyim) mitzvot of headcovering and beard maintenance, and possibly other mitzvoth that I have since lost track of due to their commonality in my day-to-day life. Shomer negiah is another influential factor that has aided me greatly, both in body and spirit BS"D.

With regards to Mashiach, of course I look forward to his coming with every day. I have my doubts that it is the Rebbe, or Yehoshuah bin Miriam, or Mohammad, or any other type of messianic figure. But, like any other mortal in this created plane (all the way back to our eternal grandparents Adam and Chava), I have come to realize that at best I must content myself with not knowing. If it happens that he is any of these figures, so be it. Petty things like a human prejudice must never impede one's freely-chosen acceptance and execution of G-d's perfect will (forever Blessed Be H-s Eternal N-me!!).

A couple of miscellaneous things to wrap up with. I consider myself to be a student of both the RaMBaM's timeless Mishneh Torah and Rav Moshe Weiner's Divine Code, though I primarily hold myself accountable towards HaShem and His perfect Torah (and pure monotheistic worship of The Former, at that). As with the members of all nations apart from Kollel Y'Israel, I am a Noachide to the core, bound by the seven eternal laws of basic human civility entrusted by Him to the pre-Patriarch Noach (may peace be upon him!). I can only hope and pray to HaShem that one day, only through His Grace and my owm Mitzvoth, I may become a Chossid.

Thank you very much for your time. Shalom Aleichem to any who sees, hears, and reads this. :)

There was a time when eating kosher, praying and Shabbath was a serious deal to observe, since I noticed that it was not commended for me. So, anything that envolves blessing with "asher kideshanu" and kind a fell into a nihilism... I do not do anymore. But I can't stand eating pork, seafood (shrimp,oister...). I mix milk with non-kosher meat and I feel guilty... Reflecting about my purpose in life by the noahide mitzvot I found that I righteous live was living morally and seeking to do justice. Since then I got much more aware about economical-political influences in a moral life. But there's still a hole in my soul waitting for something to fill in.

would prefer more fellowship to study Torah

I prefer not to respond

I prefer not to respond.

I prefer not to respond

I prefer not to respond.

I feel that there should be more resources for Noahides that are linked or connected to jewish websites. Most of the time, Noahides begin their journey through learning about Judaism. It would be nice if there were links to noahide material or groups from these websites. :)

From 1995 tried to pass gijur but... long story, and now I want to be Noahid. I think that if I am prepaired for converting then G-d will give me a sign, if not then I will do what I have to do.

i prefer not to respond

Until recently I had no idea there was a Noahide community. I just know coming out of churchianity and its falseness that I wanted Torah and all its truths. I didn't know it was called something. I think I am a blend of Noahide and want to be Jew - as I want all that the Torah describes. 
I prefer not to respond

I do not see myself as a Noahide.

I'm good with it all

I live as a Noahide until my conversion to Judaism is complete. I have always been Jewish at heart but raised as a Christian until I found the TRUTH in the Torah. My life is changed forever and I live in peace in $\mathrm{HaSh} 3 \mathrm{~m}$ !

I feel it's a very lonely journey. I miss the socialization of church, I miss having friends to talk about God and scripture with. I've often thought of returning to church, but when I go back I realize I just can't do it. There is no way I can go back after learning what I have learned. I can not accept their beliefs. I pray some day I will meet up with others who are as passionate about being a noahide as I am.

I do understand now the moral bind of $\mathrm{G}$ d's laws. To begin with, its my choice. I am free of my father's binds. Its my moral observance and obligations free of any external force or coercion. I strive and am responsible for myself first, to begin with... Thank you.

The movement is still in it's infancy (even though very old).

Chabad.org has helped me greatly and now asknoah. I love Judaism and the knowledge of the people and am glad to have a place as a Noahide.

I hope and believe that the diffusion of Noahidism worldwide will change the widespread negative stereotype of Israel and Judaism.

As for myself I am also an ordained minister since 2009. I keep the reverend title because it help me open the doors to speak to Christians about Noah laws and how it is part of our lives and hope this will open a beginning to open a small building for gatherings and having bible studies. It is in my heart to spread the word of Gd and the laws that Hashem gave Noah.

Halakha for noahides is very confusing, many things are unclear, there are also many contradictions between different rabbis.

I am thankful God led me to this knowledge.....and beyond!!!! Raised Presbyterian, SDA for 18 yrs, Noahide 10 and now...metaphysically eclectic....lol

i listen \& read:

http://lazerbrody.typepad.com/

https://www.youtube.com/user/EmunahChannel/videos

https://www.youtube.com/user/torahandscience/videos

https://www.youtube.com/user/ChabadDT/videos

https://www.youtube.com/user/7200beverly/videos

https://www.youtube.com/user/TheTruthOfTorah/videos

http://www.torahanytime.com/

http://www.chabad.org/

http://www.breslev.co.il/

Shalom Arush

Rabbi Bloomenstiel and Pirchei Shoshanim have created an excellent course for Noahide halacha and a functional liturgy for weekdays, sabbath and holidays. It is up to us the Noahides to grow it as needed. We don't engage with the local jewish community as it is mostly reform and at this point we'd like to first establish our identity as Noahides independent of that community. We'll start a weekly study in the fall and possibly some weekend worship service.

I hope this has been of some small value to you. 
I reached out through my work/volunteering after discovering and being introduced to the laws of Noah online. I work as a carer and we have a residential village founded by Jewish Families and run on Jewish traditions/ways. I asked to attend a Shabbat there but was redirected to a local synagogue which I did not know existed. I was very shy to ring and used an online form to apply for Friends status. I prayed throughout. I was contacted by phone by a Lady who suggested I speak directly to the Rabbi! o my.... well through the Grace of G-d I did this.... and it was an amazing experience and I felt truly blessed. something inside of me lept and it was like talking to a dear long lost Friend who just knew everything and counscelled me and.... well, the end result was that I received an invite to attend Shabbat with them and be met by a Lady and assisted, however I still felt I needed and would feel better attending at the Village with the Residents, and I did this and it was enough and taught me all I felt I needed to know and experience because what I learnt was that I was welcome and not excluded. I also attended a Noahide Meeting in the Chabad Centre in London. this too was a great experience for me and taught me a lot. today I am connecting through Breslev and still am in touch with AskNoah in a spiritual place where I have found peace, because I didn't need to be in a group or have other humans around me to reinforce my belief what I needed was to know and find my place and feel acceptable and able to reinforce daily my connection with G-d in a world that often does not make sense to me and that - was enough. so today my Friend I like to ask that you be blessed in your study and that some how your work assists and helps all G-ds People. thank you for reaching out and enquiring and learning and more than that... sharing. G-d bless you more.

I prefer not to respond

I am 77 years old, was an evangelical Christian for 58 years before discovering Judaism and the Noahide path. My family does not want even to hear about my new faith. They feel betrayed by the family "matriarch" who should, in their opinion, be setting a Christian example and carrying on with Christian tradition. Living in a Christian household is a real challenge when Christmas and Easter roll around. Only one of my 5 daughters has joined me on the Noahide path, and she is very concerned about who her teenage children will marry. Being a Noahide is a very lonely proposition.. Even though I occasionally attend services at the nearest shul (30 miles away), learned to read Hebrew from them, and am treated as one of them, they do not understand the issues that I have to deal with as a Noahide. And they do not have the knowledge of the prophets that is necessary to help a former Christian untangle Christianity's false doctrine. (My rebbetzin, who is a gifted teacher, said she only knows that part of the prophets which is covered in the haftorah.) Consequently, the online Noahide community is really my shul, and the rabbis who post teaching videos online are my main source of instruction. If there are any Noahides within driving distance of my home, I have not discovered them. In spite of the loneliness, I would not trade the experience and knowledge I have gained in the past four years for anything! I hope I live long enough to see more rabbis address the need for classes specifically tailored for Noahides. Meanwhile, I study daily at home and suck up every bit of "fellowship" and knowledge I can glean from online sources.

Hostility, refusal to ask questions or listen

not sure how to respond. Im not in any close assoication with either community.

I am not familiar with any Noahide communities in Scottsdale, AZ. We had attended a Messianic congregation for a number of years, but I would not even know where to look for a Noahide congregation!

I'm trying to start a community in the Tampa Bay area but its been a challenge because of onr thing or another. There are a few families here that consider either conversion or study Noahidism

I am so interested in learning as much as I can about being a Noahide and our relationship with the world. I study Torah daily and am learning Hebrew. I want to meet other Noahide but have not yet.

EVERY type of Jewish Community is in this city: Orthodox, Reform, Lubavitcher Hasidic, Messianic Jewish Synagogues (more than one), etc. But NO Noahide Services are listed anywhere! 
The lack of a community makes it difficult to practice. While there are online communities, they tend to be inactive. Noahidism is a very lonely road

I was first exposed to the word Noahide just a few years ago. I don't remember how or where. I was interested, so I looked it up online and went on a little Wikipedia spree. I was totally into it, but I forgot the word itself until receiving the invitation to this survey, whereupon I repeated the same Wikipedia binge. It's good to be reminded that we are not alone.

prefero nao responder

We need communities

After I know something about noahaism forom a ortodox jewish man (2004) I started to make a blog http://www.benenoach.info where I put every thing I learn about. It is the fist and the only italian website about noahism! Then after one years (I was a christian) I wanted to be circumcised to have a cut with my past and I started to study to be a jewish. Now (2015) I am part of jewish people as reform jewish man! I continue my stydy $i$ jewish things and noahism also in facebook! If you whant you can contact me

Orthodox Judaism in the UK is not at all warm or welcoming to non-Jews in my experience. They also make conversion extremely difficult. For example, before appearing before the Bet Din, one is expected to live with an orthodox Jewish family for perhaps up to three whole years.

There also appears to be a colour bar, in that non-white potential converts appear to be particularly unwelcome; I do hope that I am wrong on this front.

I text the Rabbi in Launceston from time to time. I would like to become Orthodox - there is no easy way. In Tasmania there would be 10 practising Orthodox Jews in the entire 512,000 population.

I prefer not to respond

I prefer not to respond

I am content and at peace with G-d. I have always unlnowingly followed the laws of Noah. It was a mitzvah to learn that my values, and beliefs have always been Jewish/Bnai Noach. I'm still learning the Tanakh, and anything else I can study regarding my beliefs.

When I first because a Noahide I had a vehicle and could go to shul at Chabad. But when my vehicle died, it was not possible for me to get there. If I had a way I would be there every Shabbat and definately for the High Holy days. I love HaShem! I love Israel! And I love the Jewish people!

The Noahide community in Singapore meets fortnightly at Jacob Ballas Centre for Parsha study under the guidance of a young and promising Rabbi-in-training Yehuda Cohen. The average attendance is $5-10$ pax. Most of us were messianic Christians before hearing about the Noahide movement. We advertise the Torah Study Classes on www.meetup.com and www.torahforgentiles.org. A Filipino guy from Manila (formally a Christian) found us online and met up with one of the Noahides while he was on a business trip in Singapore. He couldn't find any Noahide community in his area but was keen to start one. About 2 months back we had a local Singaporean guy (formally a Buddhist) joining our fortnightly meeting. He is now a regular. Uncle Arthur, our Noahide leader is actively sharing about Noahidism in churches. Please join us if you happen to visit sunny Singapore. Baruk Hashem.

I am fortunate. We have a community here and meet weekly and once a month with our Rabbi through skype. We have another Jewish teacher who has been coming to teach us for several years. I can recognize that Hashem was leading me for many years, but it took me through the Lutheran church, Baptist church, non denominational church, Pentecostal church, and a messianic congregation. But since leaving idolatry I have been learning and growing every day.

none 
B'nei Noach or Noahide is a very generic term.... Everyone is a son of Noah in the literal sense... I tend to think of myself more as a Ger Tzadik "righteous non Jew" it is much more of an accurate description. However, the term "Ger Tzadik" has evolved into a vulgar usage for the term "Jewish convert". I would like to refer you to the book "The World of the Ger" by Chaim Clorfene who is also the author of the "Path of the Righteous Gentile"... I wish you well with your research...

I have found that the teachings of the Rambam on halacha concerning the Idol worshiper have been wrongly applied to the Noahide causing undo division among the community.

Noahide exposure is minimal. I think there should be more, but some Noahide literature I've read presents Goys as greatly inferior and unworthy to study Torah. I also don't like the impression that if a Jew wants to beat me up, I am not allowed to defend myself. Being raised Christian, the exposure has made me appreciative of the Jewish contribution to the world. I thought of converting several years ago, but Judaism seems like an ethnic religion where I can never really be part of it, though I want my children to be raised Jewish, because I think it is the most wonderful culture one can belong to.

I feel there so much confusion out there with us. It is hard to filter what is allowed for us and not, accepted or not by the Jewish community. It seems everything we study there is an exact opposite. It has been a real struggle for us here especially since we only have dial up and cannot get another service. I am forever grateful for those who do have some answers and have gone before us. The best advice I got to figure all this out is what do the majority of the Rabbi's say about us and go from there. It is very lonely and at times scary when people find out you are one. We have lost all friends and many family members. I was at one time in my life studying to be a pastor and was a deacon, when I left with my belief I became avoided and thought of as crazy. I am sure others have experienced this like we are too. I hope this helps you.

I would like to have Noahides close by. Is very difficult to find any. Going through life as a Noahide is hard in certain occasions, specially when your significant other is from a different religion (I'm talking about Christmas and things like that, or raising children as Noahides when one of the spouses is not one). Having support from others that are going through the same thing is so needed. Other than that, I'm very happy to be one and will never look back.

BABYLON WAS NOT SO MUCH PUNISHMENT BUT RATHER EDUCATION FORCING TORAH BEHAVIOR RATHER THAN SACRIFICE. TWICE THE TEMPLE WAS TAKEN AWAY FROM THEM. THE COMING THIRD TIME IS GOING TO BE THE DEATH OF US ALL. BUT THEY DON'T HAVE A CHOICE IF THEY ARE TORAH OBEDIANT JEWS. YOMA 39 SHOULD HAVE TAUGHT JEWS THAT RABBINIC JUDAISM IS VALID.

I am Jewish in terms of having converted. Yet I want an orthodox conversion so I have at times felt (since a conversion not done under orthodox auspices is not recognized) that I am still connected to the Noachide. I am the youngest of a generation that began studying Tanakh (Old Testament) and Judaism in the Deep South primarily in pre-internet times and you had people from Christian backgrounds studying with Messianic Jewish teachers like Zola Levitt and learning from Orthodox Jewish Rabbi Chaim Richman (Temple Institute) and even Vendyl Jones (Noahide). These people all ended up in different areas (some today are Messianics, some are Jewish traditional or liberal, and others are Noahides or something in between). I meet people all the time and we know the same people even though we've never previously met. Today that would no longer be so. The internet changed things and now tons and tons of people (so it seems) are into Noachidism/B'nai Noach. That wasn't much of an option in the book reading/pre-internet learning day. I'm not even thirty years old, so that's why I say I'm the last of that group. Today there is so much more available information and learning and options available for free or next to nothing price-wise online.

I prefer not to respond 
I know the laws of Noah are correct and apply to gentiles, most Christians have no idea about them and many reject the concept completely, as they don't know the bible and can't determine if they are correct or not, so they reject them as they haven't heard of them before. I know they apply, but I don't see any need to make a religion out of them. They are correct, and one doesn't have to believe in them to follow Christ. They aren't a salvational issue, hold whatever position you like, it's not important at the end of the day,

Too few and far in between at this time to form real communities. Perhaps some day. I am content with online communities.

Our Rabbi is Rabbi Richman. Our Moreh is Shmuel Peak. Our web site is www.bfm101.com or www.torahfaith.org.

When I am in a hospital, I identify my religion as Judaism because few people have heard of Noahidism. Some people think the Seven Laws of Noah are a Christian denomination.

Once, I started to attend a Noahide Convention but was unable to go.

I had intended on signing the Noachide declaration during a conference. I have been raising my daughter in the Reform Judaism community in St. Louis. Since the last one was cancelled and the Chabad has stopped supporting Noachides, my family is becoming fully Jewish. It is still challenging because we are politically and philosophically (worldview) Jewish Right (Tea Party Conservatives). Many Jews still think Jewish Right means Messianic Jews which emotionally stings because I haven't been a Christian since 1990. I was glad to see the New Sanhedrin and High Court dissolve, but I believe the movement dissolved with it.

Within our area there are only Christian Churches and some East Indian Temples. I would love to see a jewish group closer than the 380 mile distance that is currently available. I am hoping with the rise in both Noahides and those who seek Judaism that there would be an encouragement for such growth on a local level. We are farmers and so can't relocate and there are others in the same situation so having a rabbi and a jewish community grow in these types of areas would benefit so many people who want to serve the Gd of Israel and also to help them grow in their faith and obedience to torah. The movement we are experiencing that is leading so many people to the torah is I believe non other than Gd. We live in exciting times! Thanks for letting me fill out this survey. Hope this helps, warm regards

I would like to respond but it might be too lengthy for this survey.

Prefer not to respond

The following are opinions and not experiences:

Reform is a huge problem. The state of Israel needs to be more Jewish and conform to the halacha, including its laws governing the non-Jews in the land (including upholding noahide courts). I suppose that is a question of time. I think it's important for non-Jews to know about the Torah and the obligations of the Jews but I do think observance of jewish rites and rituals in a jewish way (albeit one that is halachakly permissible, such as breaking shabbat at least once) should be highly discouraged. There is no good reason why goyish men should wear tzittzit, nor kippot. It introduces the danger of other jews, or non jews, seeing someone who they think is a jew doing something that a Jew shouldn't do, such as going into a subway restaurant. bad, bad. 
Well I already wrote a lot in the other question how I came to identify as a Noahide and why I continue, but I guess there is a lot to say on this subject. Like many other Noahides, we say "what now?". I'm in that phase. I came to the Gxd of Israel, but what do I do now? There's so much debate about what the non-Jew can and cannot, should and should not do..its overwhelming to determine "what is right". I guess the easiest way of coping with this is reading as much as possible, and just "making a decision". I found the link to this survey on a youtube video regarding Shabbat for Noachides. This is a great example of people strongly on both sides of the issue. I am personally choosing to celebate and honor Shabbat, but not the exact manner that the Jews are commanded to (since I am not a Jew, and I am not commanded to). I suppose I will continue "just making a decision" about my practices until there is more objective information available, or until we reach a point were $99 \%$ of Jewish rabbis are on the same page. I have thought about converting to Orthodox Judaism, but for now, being born a non-Jew, I'm going to give being a non-Jew my best shot. I don't want to just convert out of frustration or out of the confusion of being a Noahide, and desiring clear do's and dont's. If I ever do convert, I want to it to be for the right reasons. I would say thats the biggest struggle we have today (lack of objectivity, lack of agreement). A second would be the issue of community. That is what I'm struggling with right now. Jews have had difficult lives, the world hating them, etc, but they always had each other. As a Noachide I literally do not have one friend, one person in my life who believes what I believe. They are either Christian, athiest/ agnostic, or they believe we have some sort of $\mathrm{Gxd} / \mathrm{Creater}$ figure, but dont believe anything specific and arent on a quest to find out more. That is very hard for me. I'm engaged to an athiest/agnostic and he's "cool" with other peoples religions but it scares me moving forward. I'm looking for a new job, very possibly moving out of state (leave Socal), and we will see happens! I dont know what my new "Noachide life" is supposed to look like so I dont know what to do! I wish more than anything I knew a single person in my personal life (not virtually) who was on the same page I am on. I feel like they are all over the internet, thousands of them! But why dont I know them? Where would I find them? I likely wont find them in a church or a bar!! So I think it would be good for Noachides to know "where to go". I know the chabad.org organization is geared to helping the wayward Jews come back to Judasim in any way they are capable, but I wonder with this huge national (or maybe even international?) network already in place if they might have "something" for the non-Jew. I'm interested in this study you are conducting. Best of luck to you.

I observe the Seventh Day by reading the parsha and listening to George Brock's sermon online at Noahide Nations.

Too vague of a question

The biggest issue I see is that there isn't currently a centeralized source of information or worship.

It seems people are all doing their own thing in their own way, and there isn't an organization that really does a good job of bringing everyone together.

Thanks alot for your concern about noahide and judaism.

Am a noahide and sometimes we face many charages becouse many people they don'd understand, what is a noahide,most of our family our family member they serspect us as we are out of our minds,so they live with us with watting to see what will happen later.

The other side jewish people they don"t accept us in the synagogue,at sametime we are under judaism.

please if its possible,in any synagogue it could be better if can have somewhere noahide can be accepted and have classes,coz many noahide were extians but they are not having classes to make them grow,

Another thing is the language in Africa there those can't read or write and they have accepted to keep the seven laws. Some they want to be noahides but they cannot read for them self they need teachers who can uderstand local languanges.

Thanks alot once again. 
In one of the earlier questions you distinquish between "Catholicism" and "Christianity". This is a false distinction. Ctholicsm is a subset of Christianity

I prefer not to respond.

I prefer not to respond

I prefer not to respond

To me being a Noahide is how i conduct myself my life It is between me and Hashem we talk often about everything and he sees the way others see me and he knows what i don't know and he deals with them. If Hashem wants me to make him alive in someones life he sends me there to them and them to me, many friends $i$ have and Life is full of fun cause i know I am in good hands with the creator.

SO MANY BLESSINGS ALL FROM G-D EVERYTHING EVERYTHING EVERYTHING comes from G-d.

We have no community.

I prefer not to respond

One thing is for certain, I do not like "Noahidism" because unlike in other occurrences where it's just a matter of semantics--this is actually quite a big deal. I hope you talk to Dr. Schulman about calling it an "ism" as if it were a religion.

What we currently need is some non-online structure and support. We need jewish rabbis to step up and teach those who are begging to learn. Maybe I'm in a particularly unwelcoming area, maybe it's a trend. All I know is that we need teachers, leaders, organizers. We are legitimate, and rabbis across the globe need to wake up and step up to the inevitable next stage!

I prefer not to respond

I really would like to meet in person with real Noahides. I'd like a Rabbi to guide me, or a Jewish Torah Scholar. I am interested in conversion.

I prefer not to respond.

I prefer not respond

I prefer not to respond

I prefer not to respond.

We absolutely need a siddour and we need to know how to celebrate the holidays.

I originally got on line and asked aish.com what a gentile was to do, he referred me to the book the path of the righteous gentile. changed my whole life. Used to live in another area where i had good relationship with local jewish congragations orthodox modern and chabad. now where I am i am carless so have not yet got involved in local community due to distance. Also learned a lot thru the program paltalk and the virtual yeshiva. now defunct currently an admirer of breslev.co.il and reading the world of the GER. Great book.

Judaism and Noahidism change my whole life and my definition and perception of the purpose of life and the best thing of it is getting myself out from idolatry and its lies.Baruch HaShem. 
Judaism is unpopular religion in Indonesia. The majority Muslim population of Indonesia see Jewish and Judaism as an enemy of Islam. So, as a Noahide who believes in Judaism, I have to explain carefuly to not to put myself in an "enemy" position. The traditional Christians of Indonesia just don't really care about Judaism and no nothing about Noahide movement. But for them, Jewish people are God's chosen people, so it is easier to be with Christians, but they will always try to bring you to $\mathrm{Mr}$ J.

First off, I'm convinced that the "movement" has lost a good deal of its vitality. I also think it's long overdue for a rebranding. No Noahide likes the term "Noahide", and we're often perceived as members of a cult. I'd rather be called a Goy - a member of the nations - than a Noahide.

Secondly, I find many Noahides strange. Many carry religious baggage and expectations from their previous religious lives. Their interests are largely spiritual, and their interest in Judaism often leads them to engage in activities that are far too Jewish for my comfort, and the rabbis often entertain discussions of their desires to become more pseudo-Jewish. Also, many Noahides don't care to read, and what they do read is sometimes questionable.

My interest has always been in the law of Dinim and what it might mean to have a legal system for nonJews that upheld the Torah. What such a system might look like and what a society based on that system would look like. My spiritual overtures are very minimal in nature; I've always been interested in the practical / ethical side of Torah - of what it could offer to the world. I also tried hard to not "look like a weirdo" as a child. A difficult feat.

I'm convinced that without a rebranding and without a more practical angle to the Noahide issue, the movement will remain as dead as its been in the last 15 years. I also think that Noahides rely too heavily on Jewish leadership, distrusting their own members. Every Noahide has different opinions regarding the Noahide event. Without a mind geared towards visibility, activities, actions, and goals, though, it's a dead movement. Goodness, even the anti-Noahide movement has always been more robust than the Noahide event has been.

I have many thoughts on this matter (including firm opinions of what's needed to spur the Noahide movement into action) and I've had many formative events in my life regarding my Noahide upbringing. I'm not sure what your angle is. But although I've found a core of Noahides that think as I do, I don't know how representative we are of the community. Most of the visible community is quite religious, it seems, though many of these individuals only end up converting.

Wishing you guys well on your ventures. Let me know if I can be of any assistance. Incidentally, I worked at FIU's BBC campus for years in their library, and I received my BA in Philosophy with a Humanities minor from FIU. At the time, I wanted to see what secular thought had to offer. It's got nothing on Torah, though. I also attended your R' Steinsaltz event years back. It was amazing. Keep up the good work. 
Just like there are many opinions about Torah and within Torah, even apparent contradictions, these discrepencies carry on into argumentation between Noahides.

I see some that, due to such a desire for personal/national autonomy, are borderline anti-Rabbinic, and see the Rabbis as trying to create a religion for non-Jews (personally I don't see it, but I've seen this attitude amongst multiple of the most-learned Noahides. Often times these ones are most interested in justice within their own communities, and a desire to setup their own dinim, often times without any knowledge and/or examples of how to do so.

On another hand, I see those that are super interested in Torah study, the commentaries, and winnowing through these for what is applicable in drawing near to Hashem (how do I pray? can I keep Shabbat? can I lay Tefillin? etc.). Although I am 100\% behind the love of the Rabbis and Torah therein, these Noahides often have little care for the laws of their own nations, also forgetting that there are righteous gentiles amongst them - even those gentiles that have neither knowledge of Noach or Torah.

None of this is surprising, seeing as Israel has not been entirely gathered, there is yet no fully recognized Sanhedrin, and within Israel there are those who do not love their neighbor - indeed, even saying hateful things about their fellow Jews. Some even get angered amongst one another on the relationship between Israel and the rest of the goyim, some saying non-Jews are important if not essential in the Jewish mission, and others saying all they have to do is worry about their own. One Noahide hears this and thinks half the Jews care about him, and the other half could care less. Another Noahide hears the same thing, and thinks half the Jews want to control non-Jews, and the other half don't care how we govern ourselves.

A primary issue "that the Noahide community is facing at present", is lack of community, not only amongst ourselves, but also with our Jewish neighbors. The Lubavitcher Rebbe taught an association between the spread of the Sheva Mitzvot and the coming of the Messianic Era, but if the local Chabad house has next to no interest in anything but Jewish outreach and continuity, how are we to draw nearer to Hashem, His Torah, and His people? Without this and more, how are to have Achdut Kol Adam?

There is no Noahide community.

we just celebrate Shabbat at home together with my wife and kids. as much as posible we would like to observe the holy day the Jewish way but it is hard considering our location and we dont have a community here for Noahides. but we enjoyed obeying the Laws.

Lack of community. I want to establish a sustainable community in India. I plan to do that by earning enough and saving lives through healthcare. I believe Noahidism to be a missionary religion, the only true and halakhic universal religion desired by HaShem. Noahidism will originate in India and establish the Kingdom of HaShem everywhere.

Now i am working here in saudi arabia as an Overseas Filipino Worker. I am alone and lonely as a Noahide, because there's no else to talk to.! my family is in the Philippinese and $\mathrm{i}$ am happy that they are in the Hands of G-d. And daily they take prayer, lecture and talk to some noahide community. B'H

I prefer not to respond.

I Prefer $\mathrm{n}$ to respond

I can't write this real clearly but the fact is I'm not allowed to be seeking a rabbi's help. It brings me to tears. So I write emails to Dr. Michael Schulman, Director of AskNoah International whom you must know, I'm sure of this, and he promptly and happily and really sincerely writes answers that I need. He introduced me to an online friend and we email back and forth and she is a Noahide. The one person other than Dr. Michael whom I trust in my life.

I prefer not to respond 
I prefer not to respond

After a 25 year exploration of all four categories of Christianity, I 'm delighted to identify with the Jewish people . I've also explored most of the varieties of Judaism which was wonderfully much easier . I do have a casual fascination with the structure of Jewish worship , prayer and Jewish wisdom in general .Perhaps the best thing is how I walk the earth less concerned with what people believe and more focused on how they behave. Good people will continue disagree about the big questions in life while agreeing about basic human decency .

I want to share that www.asknoah.org is the "'go to" place for Noahides. Asknoah.org can be trusted in terms of the authority of the Torah (halachah). That is enormously important! Also for Jews and Noahides another absolutely vital place is Www.divineinformation.com. I can't express how enormously important these two places are. 1000s of free lectures and films about Torah and Science, Life after Death, and a new one explaining why we are here and so forth. I would also like to say that while religious Jews are awesome, don't expect them to always be perfect, because they are just trying their best too. I think with a bit of knowledge people can quickly see that xtianity, islam, reform, conservative, modern, messanic "judaism" and other idol worshipping etc doesn't make any sense. Also, when you learn the Torah with these two places, the whole universe makes sense and every question and worry or concern is answered with a truthful and satisfying answer. It's the best thing ever. One thing or so I saw in this questionnaire that was odd was the question about kabballah. Any kabballah place one would see, like in LA, is not real kabballah/quaballah and is evil. Only certain older married Jews can delve in real kabballah in the Zohar, and there is no need to dwell in there, because there is a huge mountain of learning othetwise. We can benefit from the secrets of the Zohar anyway. Thank you for asking me to participate in your survey. Please proceed wisely with legitimate council and approval of approximate people like Dr. Michael Schulman, Torah scholar and physicist, who works closely with top religious (orthodox) rabbis at www.asknoah.org.

For me, Bnai Noach is more of a title than a religious system. It suggests that while I am not a convert, my faith is Orthodox Judaism. While I do not adhere to all the mitzvoth incumbent upon a male Jew, I still regard Torah Judaism as truth. This is how I explain it to others who are not familiar. I don't go to a "Noahide church or synagogue." I listen to, learn from, and stand with Orthodox Jews. Locally, we have a conservative synagogue. I have been a few times however our beliefs do not align perfectly. About 3 hours away, there is an Orthodox synagogue. I have also visited it, and it was a great experience. I would attend it more frequently if it were closer. I was welcomed with open arms. I adhere to the seven mitzvoth and even slightly beyond where I can. Living in the "bible belt" of America presents many challenges to living a Torah observant lifestyle. This area is simply not concerned with such a thing. This makes it difficult but we do the best we can. I try to respect Shabbat by not going out and buying things, instead staying home with my children and listening to teachings or reading the parsha. Bnai Noach is freedom from the dream world the church has created. I liken it to the film The Matrix. Waking up for the first time and entering the real world, seeing through one's real eyes. This is what Bnai Noach is to me.

I prefer not to respond

Because I was raised in a Jewish home it has been somewhat easier to practice as a Noahide but ,I believe, more difficult to explain. Some of those who know me, feel I've left Judaism but they don't understand Halakah. I am able to observe/enjoy holidays \& ritual with appropriate adjustments much easier and with less assistance than others.

I prefer not to respond.

I am blessed to be part of an organized and active noahide community here in my country (Qehilat Chasidi Umot Ha-olam, Philippines) It is full of challenges but we are happy that our community is growing, thanks to our mentors from both America (ask Noah) and Israel (Noahide WOrld Center)..and the sincerity of our mentors too and leaders here for the Philippines the brothers, Emmanuel and Abraham Villegas for the undying effort reaching and teaching the noahides the ethics and laws a noahide should abide while in this earth.... Baruch Hashem! 
I founded the Yeshiva Bnai Noah of the Bnai Noah Religious Society in Oklahoma. The Robin Hood International Human Rights Legal Defense Fund is a tradename of the Society. The Yeshiva enjoys close ties for many years with Rabbi Mordechai Goldstein of the Diaspora Yeshiva Mount Zion, and Rabbi Pinchas Waldman of Aish HaTorah and the Yeshivat Dvar Yerushalayi (where Rabbi Yoel Schwartz serves). We have helped several Chinese Jews learn Hebrew and make aliyah to Israel. We have translated numerous works into Chinese regarding Noahide law.

Baruch HaShem Abba

I prefer not to respond.

Been a Noahide since 1985

Studied at Atlanta Kollel 1988 to 1990.

Written several books on Noahide Law.

Most jews don't know what we are...jews and noahide need to bind together....that is what it is about. We were created to be a team.... thankyou. Shalom

More communities to built. Acceptance of Rabbi of welcoming Noahides in Jewish communities. More involvement of Jews especially Rabbis in sustaining the growth of Noahide communities in providing spiritual guidance and support.

I prefer not to respond.

I live in eastern Washington state. Not much contact with any other than the synagogue in Richland.

A regional TV station had many messianic and Jewish guests. I found their teachings interesting. It was through study in preparation for teaching classes on Catholicism to children and adults that I learned enough to leave Christianity. Incidentally, Catholics are Christian. Not some other group. I purchased the book that taught me what Jews believed at the author's store in Israel.

I have never fit into a religious setting until I accepted the Seven Commands. Now, i feel free to serve HaShem and study Torah.

I'm very thankful

I prefer not to respond.

We need more visible communities, facilities, gift shops, resources, you name it. It will take time as more people come into the faith.

I'm blessed to finally be a part of a very active near by Noah ide center for study and fellowship. In Humble Texas called Netiv. Also a very active website called Netiv.net. Before I married my Noah ide husband I was a part of an active Noah idea group in Lubbock TX called South Plains Hebraic Heritage Center under Rabbi Chain Richman guidance from Jerusalem.

Thank you for your work in this direction. I only wish this kind of work publication brings about awareness among people about Noahidism. All non-jews are noahides by birth. Only they are not aware.

I am 58 and $i$ have been Ger for 4 years. I am so in awe that HaShem brought me out of Christianity and showed me the truth. Why He would bless me so still leaves me amazed. I only wish that we had a Noahide center here in San Antonio, Texas. I know there are more Noahides here who just don't know where to go. I read every book I can on the Noahide Laws. I tried to convert 3 years ago and because I am disabled and on disability it did not work out. I decided to remain Noahide. I love Torah and i love Israel and the Jewish people with all my heart. Torah is my life blood. When ever I get depressed, it is because I have not been reading Torah. As soon as I begin reading again, I am fine. 
I would be happy to share findings in books such as Acts and Galatians and how they actually related to Noahism.

I attend Netiv Center for Torah study in Humble TX

The main concerning is related to don't become Noahidism a religion and understanding that it's not Judaism for Gentiles, but a related but different way and if somebody is interested on convert a Jewish, then that person should be encouraged and not told that he/she is a Noahide and must remain like one as some chasidic Jews teach.

I am currently converting and when i become jewish i would like to have some focus on noahide and jewish relations and help improve those bonds and nurture and help noahide communities

we are a group of people studing Judaism in Ghana if any Rabbi out there would be so kind to help us

We meet with a few in our town Friday nite to celebrate the seventh day as Noahides, not as Jews. Once a month we come together with others throughout the area and study Torah all day until Havdala.

Occasionally we have a weekend with a visiting Rabbi and that is usually Friday, Saturday, and Sunday. Great experiences. We are so thankful for the teachers Hashem has sent our way. Vendyl Jones was the man who introduced us to this path of learning.

Judaism is the truth and is beautiful.

\section{Rav David Katz is the Ger Rebbe}

I feel alone. There are no known Noahide communities near me. I'm not welcomed to any branch of Judaism because of my desire to convert to Orthodox Judaism and my marriage to a Christian. The branches of Judaism close to me don't seem to recognize a Noahide

"I prefer not to respond."

Among even the orthodox Jewish community, acceptance of noahides and ger tzedek (proper halachic righteous converts) is haphazard - youll be reviled and/or rejected by reform and sephards (personal experience), openly accepted by conservative, chassids, and chabad and met with guarded tolerance by ashkenazi, and after proving yourself, kindness and acceptance.

My advice to prospective converts would be to approach one of the latter groups i've mentioned. Noahide observance should be done under guidance of one Local Orthodox Rabbi whom you meet in-person when possible.

i am considering a conversion, so maybe $\mathrm{i}$ am not a "real noahide", but $\mathrm{i}$ am still a non jew, so $\mathrm{i}$ considering myself as one, for now.

i pray 3 times a day, listening courses, and read text about judaism, about the Torah.

I prefer not to respond

There is currently a lack of physical community for Noahides. The problem seems to be twofold: 1) Low numbers of actual Noahides to start communities within specific geographical regions, and 2) A general confusion on the part of the Jewish community as to who we are, and what to do/not to do with those who wish to participate in Judaic practices, but not fully convert. "Why not just convert" seems to be the most common response when meeting practicing Jews who encounter those who identify as Noahides. Some of us have taken it upon ourselves to establish our own communities, but they lack the guidance of someone who is properly theologically/religiously trained to oversee operations.

Wish I was closer to a Jewish community. 
Noahidism can be a dead end for those looking for real meaning in life. It is a can I/can't I existence that can leave one feeling 2nd class, irrelevant and cute. However, it may be a starting point or a pathway out of idolatry like working at McDonald's for a teenager who will ultimately pursue a more meaningful career. The career is Ger, where we all find sustenance.

I belong to a group which consists of a few people living in one region of our country. We'll try to expand. Our teacher is a rabbi living in Israel who speaks Polish quite well. We contact with him in virtual yeshiva by Skype weekly. My friends still are thinking about full conversion and Noahidism is for them a new issue.

I think more Jews need to learn more about the Noahide Code, because a lot have no clue that it even exists. This is a dereliction of their duty to be "a light unto the nations." But the orthodox Jew is the soul of humanity. They perform their tasks faithfully.

My goal is to live in Israel, at least for a protracted period of time. I am concerned for my children, as there is little if any education or infrastructure for them.

I prefer not to respond.

Noahidism isn't a fairly new endeavor for me. After leaving idolatry I began to seek Judaism. I took a dna test revealing Jewish dna yet there was no paper trail to prove it. After meeting a rabbi (David Katz) he told me about Gerim and once I studied it, found that to be my true mazal. Though I still pursue Orthodox Judaism, I find the Ger movement to be fun and exciting due to its significant role that it plays in the restoration of all things.

In Chicago, Noahides are welcome to participate in the Chabad community. According to some Noahides, this has been a challenge in other locals.

Online there is some turf battle between different ideas about what a Noahide is and should be doing. It would help if the rabbis would relax a little about each other.

i would like to understand.

I prefer not to respond.

I used to live near synagogues and plan to again after my husband is done studying. We also hope to convert if my questions are answered more clearly.

Thankyou very much for allowing me to share,

I was born a chatolic and back in $1996 \mathrm{I}$ became a born again christian then in $2012 \mathrm{i}$ became a messianic jew and last year I discovered that this isn $\mathrm{t}$

true either don $\mathrm{t}$ get me wrong I $\mathrm{m}$ not the kind of person that that like to try things but I was always searching for the truth and found it in Judaism.

I was wathing a debate (Rabbi Yosef Mizrachi and a christian minister)) and from then i started to search if this is really the truth,then I went to the Chabad centre in Malta to see what they do and then started to study Judaism.

after some months I spoke to the Rabbi and told him that I wanted to become a Jew and if he is able to help, and he told me that it s very difficult

and he refered me to the book The divine code ,I said to him that $\mathrm{i}$ already had that book and being a

Noahide i won $\mathrm{t}$ be able to study Torah

So i took his advice and continued to read THE DIVINE CODE, and lately GUIDE FOR THE

NOAHIDE.

To become a Jew is still on my mind but for now $i$ am happy to be a Noahide.

I assined myself to do a study which start in october,(Yeshiva study program, Torah study)by Noahide nations.

If you need to ask any questions pls be free.

Thankyou very much 
While I won't go back to what I consider a flawed theology, there are numerous problems I've found with being a Noahide. First, there aren't many people identifying as Noahides so I am very isolated. Second (and this connects with the first) there are very few Jews who have heard about Noahides. Most of those who have are Orthodox. If I want to worship, where do I go? Christian churches are out and going to a shul involves educating the Jews there about Noahides. And I'm in a state with a fairly large Jewish population. Third, there are no support systems for births, weddings, deaths, funerals. Fourth, I only know of a few Rabbis who have written or are attempting to write guides for Noahides. Most Rabbis are busy enough tending to their fellow Jews. There is no clear leadership, no schools to train experts in Noahide laws, which leads to: Fifth, anyone online can set up a website or write a book that claims to offer a guide for proper Noahide behavior, explanations for the various subsets of the main seven laws, what Jewish mitzvot or prayers are acceptable -- or at least not forbidden -- for Noahides to perform. I've come across more than a few contradictions and some frankly shady stuff. One book even says Noahides can set up an altar and perform animal sacrifices!

At this point, I am identifying as a Noahide as a preliminary to conversion, trying out various prayers and mitzvot that I believe are acceptable for me to pray and do, keeping a modified kosher. Sort of getting my feet wet, making sure I can be a good Jew and that I really want to be, before I talk to a Rabbi.

It would be good if Jewish communities get more aware of Noachides and would friendly welcome them with support and education.

What a journey!

On the whole I represent one of two types of Noachide, 'an undecided', occupying the position of Noach until further notice. In that grain my worship, prayer, ethics and philosophy is ostensibly Jewish.

Once I either achieve, or neglect to achieve Jewish status, I will either become fully Jewish and support Noachism as a Jew or as a Bnei Noach. My online community is solely through Netiv.net and Rod Bryant. Without him I would be very isolated as a Bnei Noach.

There are no Noahides here in Tucson so I go to a Chabad House, but I feel like a stranger there.

I am amazed at the amount of people I know that are reaching out to Jewish texts. As a pastor I encourage it. I myself almost converted but realized it was not for me and that converting is not allowed because I believe Yeshua is the messiah

I'm very thankful that I am no longer an idolator.

I prefer not to respond

No response

I went from Christianity to Messianic Judaism, then I learned the truth and left those faiths to only rely on Tanakh. Myself and my wife and children went into converting to Orthodox Judaism. We moved into the community, my oldest son went to a Jewish school, we attended Synagogue on Shabbats, and I went to morning and evening prayers, and I began studying with the Rabbi. This was all during trying times for us, which made it hard for us to completely give ourselves to the conversion process. Plus I believe we needed more understanding and conviction for why we wanted to become Jews; for it was much to take on. We loved the community, \& the sense of belonging, but we had to abruptly postpone our conversion. I guess going from one religion that I gave my heart to and couldn't trust damaged me emotionally where I don't think I was ready to jump into another yet. We now live in a different city \& state and are new to the Jewish community we have moved into. We have yet to have done any activities in this comunity. We live as Noahides, but still don't know if we will convert. I believe there is a Noahide community here, \& if so I hope one day to connect. I also study Kabbalah to see if I can gain a deeper understanding of Torah. I don't know what's next as our lives are so busy, and the Noahide sources are few. I some times feel lost in between two worlds, but I know we are right with God. 
I founded Noahide Nations; had the first non-Jewish radio talk show on an Orthodox station called Noahide Nations; have conducted 2 world conferences; released 1st Jewish \& Noahide united music CD; currently offering the 1st and only Noahide Torah Study Course taught by a Posek at an Orthodox Yeshiva; have graduated the first non-Jews in history from an Orthodox Yeshiva; have a solid plan for growing both Jewish and Noahide communities; preparing to publish the 1st Noahide Laws book researched and written by poskim (Judges); preparing to publish the first prayer \& blessing book for Noahides written by poskim called 'The Order'; preparing to print the 1st Noahide calendar; have a successful Noahide dating site and much more.

I prefer not to respond.

I use websites such as asknoah.org and speak with teachers in Judaism. I made a webpage on Facebook called Noahide Information Page and have a YouTube account with Noahide videos.

I really love G-d and his laws and would like to see the world in his peace living how he created us to be.

I appreciate this survey, and hopefully this will contribute to a serious and respectful study of peoples the world over, who are beginning to recognize the truth of the way of life as taught by the nation of Israel through their Torah.

A point of critique on the term 'Noahidism.' It would help to define that term, or better, to simply say the Seven Laws or Laws of the Children of Noah or the Noahide Path. The 'ism' suffix, while technically accurate and compact, connotes a novelty or philosophy without roots in the antiquity of a revealed religion. Therefore, it is more fitting, in my humble opinion, to refer to the path of the Noahide as just that, and not a religion.

I've only start studying the Torah recently (the latter half of February 2015, so about 4 months or so as of now). I haven't had many experiences yet, and I am still fleshing out and coming to understand these things. My daily practises are not what I envision them to be this time next year, after I've learned more. So because I've had very minimal experiences so far, there isn't much for me to say in this regard.

What I will say is that I hope in my life-time to see the whole world, or at least a larger part of it, come to follow the Torah. I wish to see this become more mainstream, for lack of a better term, because I know from my own few experiences that to most people it is virtually unknown that within the Torah is the framework for Non-Jews and there is no stipulation for conversion to another religion like there is in Islam, christianity, et cetera.

Best regards

Noahides are not meant to imitate the Jews, expecting some sort of spiritual benefit from doing so. Currently, however, many do, which creates confusion and even spiritual problems for them. I have been around for a long time, and have done so, and have come to understand the error of it. Noahidism will likely go through some years of faddish growth, in large part because of its mainly online activities.

Certain groups of Noahides may take on some 'cultish' qualities, with shallow charismatic leaders and incompassionate judgementalness.

It will be interesting to see how it develops over the next ten years and more.

I prefer not to respond

I have children aged 9 and 6 , it would be great to have more Noahide resources to teach children of their age G-d's path, also resources for teaching groups of children i.e. Schools in my area only teach Christianity as religious education.

Not only are we not understood by non Jews we are not understood by Jews. We need more rabbis and synagogues to accept us. Not Noahide churches. That's how xtianity started. 
i have 2 websites for the diffusion of the Noahidism:

www.mundo-por-venir.org (spanish)

www.world-to-come.org (English)

$i$ have a plan for the global difussion of the noahidism, with Internet

I prefer not to respond

Many if us don't like to be called Noachides. We prefer less vulgar, more specific names, like been Noach, Chasidei Umot haOlam, or ger.

My husband and I rarely talk to others about being Noahide, mostly because we are not sure how it will be accepted and the lack of available materials to educate non-Noahide friends and family members.

I prefer not to respond.

I have been blessed by coming into contact with several Orthodox Rabbis who have taught Noahides. I currently host a weekly class with some of the rabbis and other teachers. I post the classes at www.bnyeshiva.com and invite anyone interested in attending the classes. I have been attending classes with these rabbis for about a decade and hosting the class room for almost as long. As stated before, I may consider conversion once my mother passes away, but until that time conversion is not even considered. My wife came to become a Noahide much later than I did, and there was some very minor problems with my interest at first, but now she is fully on board, attending classes and having study sessions with other Noahides.

Regarding an earlier question about participation in shul. We only participate in public events, i.e. Channukkah, or we help in a supportive manner such as assisting with children's programs. We only pray in shul when we are there for these specific times.

No local resources or sense of community.

Feeling alone. Online community has helped. But nearness to a synagogue would be great. Nearest synagogue over 2 hours away. Can not afford rent wirhin the erev area. So I keep shabbot and say my prayer. I chat in groups online on facebook. 